\title{
1984 年度春季学術大会記事
}

1984 年度春季学術大会は, 5 月 19 日（土） 21 日（月） の 3 日間, 仙台市戦災復興記念館に扎いて開催された。第 1 日目, 第 2 日目の両日にわたって, 研究発表が 25 分 (口 頭発表 18 分, 質疑 7 分) の持ち時間で行なわれ, 37 の発表 がなされた。その概要については, 以下の「発表要旨」を 参照されたい。19 日夕刻からは, 同記念館 2 階の「レスト ラン・トップ」を会場として懇親会が催され，46名の参加
を得て，会員の親睦が計られた。最終日の 21 日には，巡検 が行なわれた。仙台以南の奥州道の宿場集落の宿駅機能と その今日の景観を主テーマとし, さらに幕藩期の豪族屋敷 (蔵王町曲竹) や和紙工房 (白石市) の見学も屯じえて, 盛 りだくさんの巡検であった。詳細は, 以下の巡検報告を参 照されたい。参加者は, 37 名であった。

\section{発表要 旨}

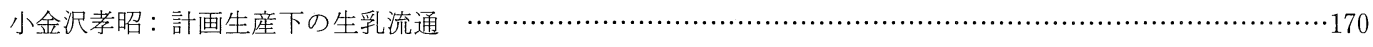

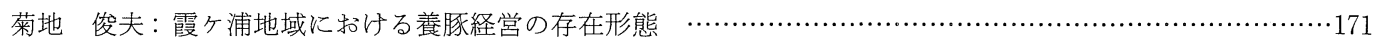

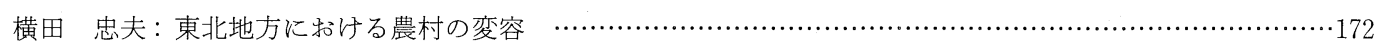

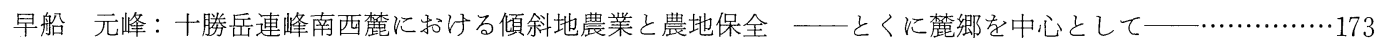

斎藤功・山本充：ブナ帯山村に打ける生業の変遷と土地・山林資源利用の空間的変化

一栃木県栗山村土呂部の事例一

田村 俊和・武内 和彦：丘陵地に打ける自然環境の空間的構造をとらえる試み

(1) 丘陵地の自然環境とその保全・開発をめぐる諸問題

宮城 豊彦・田村 俊和：丘陵地における自然環境の空間的構造をとらえる試み

(2) 高館丘陵, 中の沢地区の地形々土壤

菊池多賀夫：丘陵地に打ける自然環境の空間的構造をとらえる試み

(3) 高館丘陵, 中の沢地区の植生

三浦修：丘陵地に打りる自然環境の空間的構造をとらえる試み

(4) 高館丘陵, 中の沢地区の土缞花粉

田村 俊和：丘陵地に打る自然環境の空間的構造をとらえる試み

(5) 高館丘陵，中の沢地区にみられる地形，土塆，植生の空間的対応関係 $\cdots \cdots \cdots \cdots \cdots \cdots \cdots \cdots \cdots \cdots \cdots \cdots \cdots \cdots \cdots \cdots \cdots \cdots \cdots \cdots \cdots \cdots \cdots \cdots$

武内 和彦：丘陵地に括ける自然環境の空間的構造をとらえる試み

(6) 多摩丘陵西部に乱ける自然環境要因の相互関係

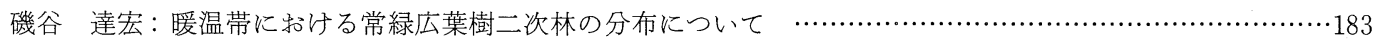

今泉 俊文・庭稲 智子。片平 博文：陸羽地震（1986 年）時の地変と地籍図

一一秋田県仙北郡千屋断層の例

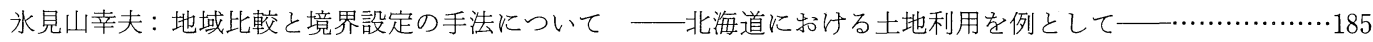

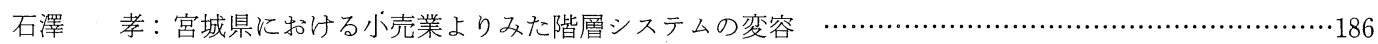

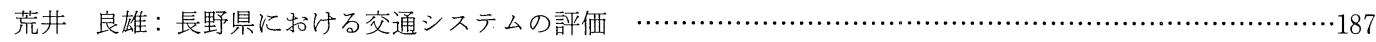

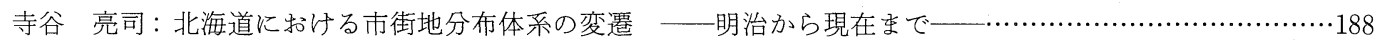

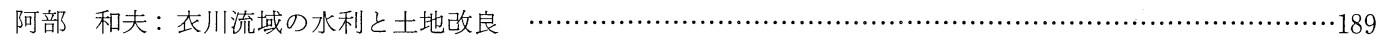

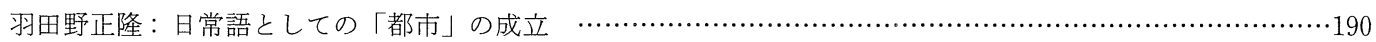

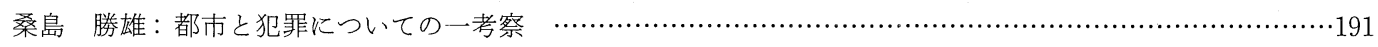

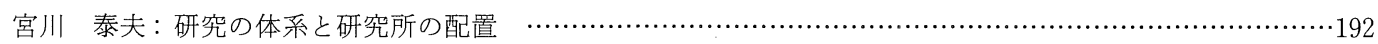

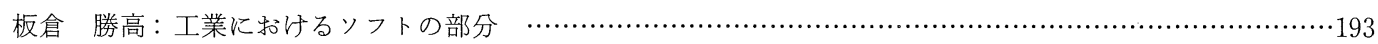

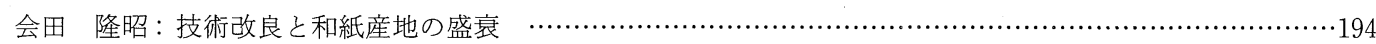

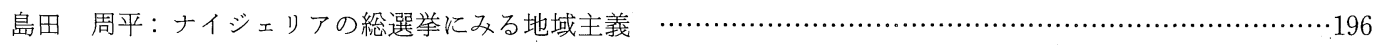

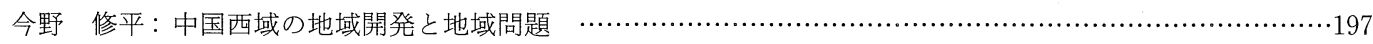




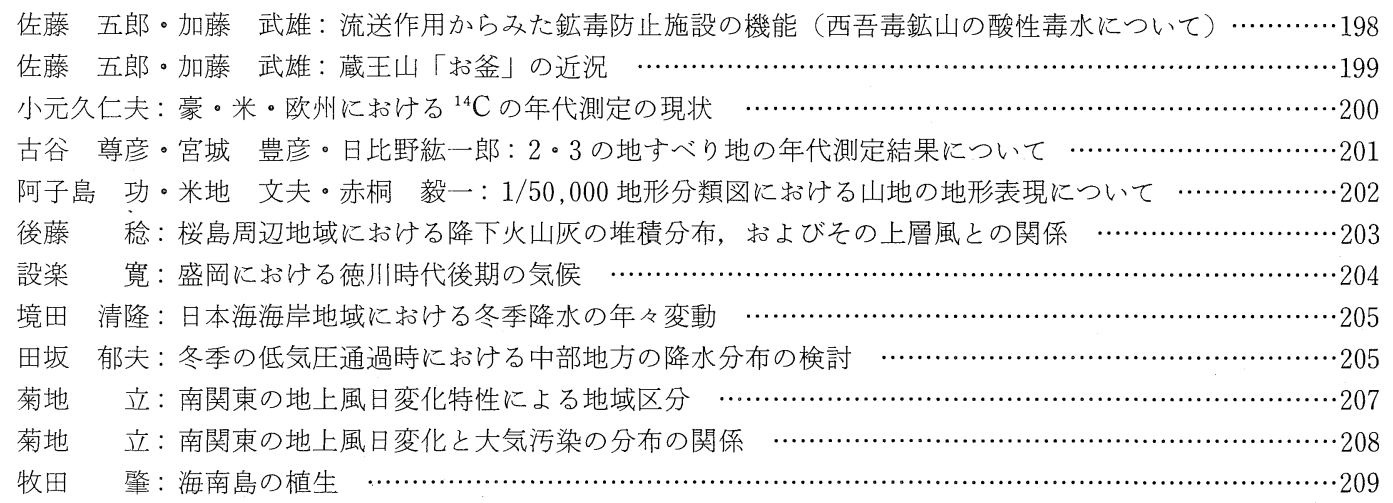

\section{計画生産下の生乳流通}

1979 年以後実施された生乳の計画生産は, 生産者の生産 意欲を著しく減退させたばかりか生乳の流通にも新たな変 化を生みだしている。本報告では, 生乳販売組織の自主規 制として実施された生乳の計画生産以後の生乳流通上の諸 変化を整理するとともに, これらの変化に際しての生乳販 売組織の役割を検討課題とした。

報告者はすでに拙稿で生乳流通が生乳販売組織の対応に 強く規定されていること, 生乳流通の地域的特徴は, 各地 域の生乳販売組織の機能や生乳市場での対応の仕方によっ て異なるとして，いくつかの地域類型を提示した。しかし こうした類型は生乳市場や組織の機能変化によって変化す るものである。とくに計画生産以後, 生乳販売組織は, 生 産, 販売両面で組織の管理機能を強めつつある。本報告で はとくに生乳流通の特徵を規定する生乳販売組織の機能に 注目して検討を試みた。調査地域は, 東京集乳圏に属する, 東日本太平洋側の諸県とした。

計画生産は, 各都道府県の生乳販売組織（生乳生産者指 定団体)ごとに割当生乳販売量をきめその範团で生産するこ と等をその内容としている。これらの施策は, 乳価を引き あげずに生産過剰を回避するものであった。生産者は, 生 産意欲を減退させながら計画生産に対応する一方で, す光 扐かれた乳価の下で手取り乳価を上昇させる方策を強めて いった。生乳の価格は飲用向けと加工原料乳向けとでは, そ の価格が異なり，前者の方が高い。手取り乳価を上昇させ るためには, 飲用向けの販売比率を高めればよい。生乳販 売組織は, 生乳の飲用向け販売を積極的に進めていった。飲 用向け販売比率を高めるために, 生乳販売組織は, 県外 の販売量を増やしていった。その結果生乳の広域流通は一
段と激化し，生乳販売組織を単位とした飲用向け販売比率 をめぐる産地間競争も激化した。

1981 年中央酪農会議は, 飲用牛乳流通の混乱等を理由に 産地間競争の規制を行い, 各都道府県別の飲用向け販売比 率の割当てを決定した。飲用向け販売比率の高かった市乳 地帯にその比率の低かった加工原料乳地带との間で激化し た産地間競争の一巡によって, 市乳地帯では, 飲用向け販 売比率の低下に対する対応が求められ，加工原料乳地带で は飲用向け販売比率の一層の桩大が求められた。これらの 諸課題への生乳販売組織などの対応過程で生乳流通はいく つかの特徵を示してきた。第 1 は, 産地間競争を通じて, 生 乳販売組織を介した流通量が増加したこと, 第 2 は, 各生 乳販売組織の販売先に大きな変更が生じてきたこと，第 3 は，领用向け販売比率を高めることを目的とした生乳流通 に招いて, 全農, 全酪連による委託販売が増加し, 全国連 の生乳流通に括ける主導性が強化されたことである。

以上の諸変化を生乳販売組織との関連で検討した。生乳 販売組織の生乳受託率の増加はとくに市乳化地帯でみとめ られる。これは, 市乳地帯で加工発生比率が増加したため, 不足払い法の適用が受けられる生乳販売組織への加入が増 加したものである。生乳販売組織の販売先の変更は, 市乳 化地带では加工発生比率の低い販売先への, また加工原料 乳地帯では, 飲用向け販売比率の高い販売先への変更とい ら形で行われた。しかし販売先の変更は, 生乳販売組織に 配乳権が集中されていなければ実行できないものである。 にもかかわらず販売先の変更が徐々に進んでいることは, 生乳販売組織の乳価交渉権の一本化, 配乳権の一本化, プー ル価格の完全実施といった諸機能が充実して組織の指導性 
が強化されたことを示している。全国連の生乳流通での指 導性の強化は, とくに, 加工原料乳地帯での生乳販壳先の 販売拡大の過程で行われた。全国連は各生乳販売組織から 委託された生乳を自己プラントで処理するだけでなく，各 メーカーへ販売している。

このように激しい産地間競争の下で生乳販売組織の機能 の強化が進んだが，その結果従来の各生乳販売組織間の機 能間格差が縮小される傾向となった。拙稿で類型化した無
条件委託型, 部分委託型, たてわり型といった生乳販売組 織の地域的特徵がその性格を弱め均等化されつつある傾向 が予想される。また生乳流通の空間的特徵としては生乳流 通の広域化として現象化しているが, 徐々に無秩序な広域 化から再編整備された形での広域化を示す傾向にある。こ のことは生乳流通が，より機能を強化した生乳販売組織間 で行われることとなり，より激しい産地間競争を生みだす ことにつながりかねないことを意味している。

\section{霞ケ浦地域に抢ける養豚経営の存在形態}

日本の養豚業は厨芥利用により成立し，採肥を主目的と した零細・副業的な養豚が農村に普及していった。このよ らな養豚は「残飯養豚」あるいは「軒下養豚」と呼ばれ，茨 城県でも 1960 年代前半まで多くの農家で続けられていた。 このことは, 茨城県の 1960 年に打ける豚飼養頭数と養豚農 家率の分布からもらかがえる。つ交り，一戸当りの飼養頭 数は少ないが，養豚農家率は高く，全県的に養豚が分布し ていたといえる(図-a)。しかし，1962 年の生産過剰による 肉豚販売価格の大暴落を契機に, 零細規模の養豚農家が淘
汰されていき，養豚を専業あるいは主業とする農家が出現 してきた。萩城県に抢ける 1980 年の豚飼養頭数と養豚農家 率の分布をみると, 養豚農家率は各市町村で著しく減少し たが，養豚が県西部から霞ケ浦北岸执よび東岸にかけて帯 状に集中乙て分布し, 明確な養豚地带が形成されてきたこ とがわかる(図-b)。ことに，霞ケ浦地域は養豚地帯の中核 を成しているため，その地域の一部である鉾田町南野地区 を取りあげ，養豚業の発展過程や農業経営に拈ける地位な どを分析することにより，その存在形態を検討する。

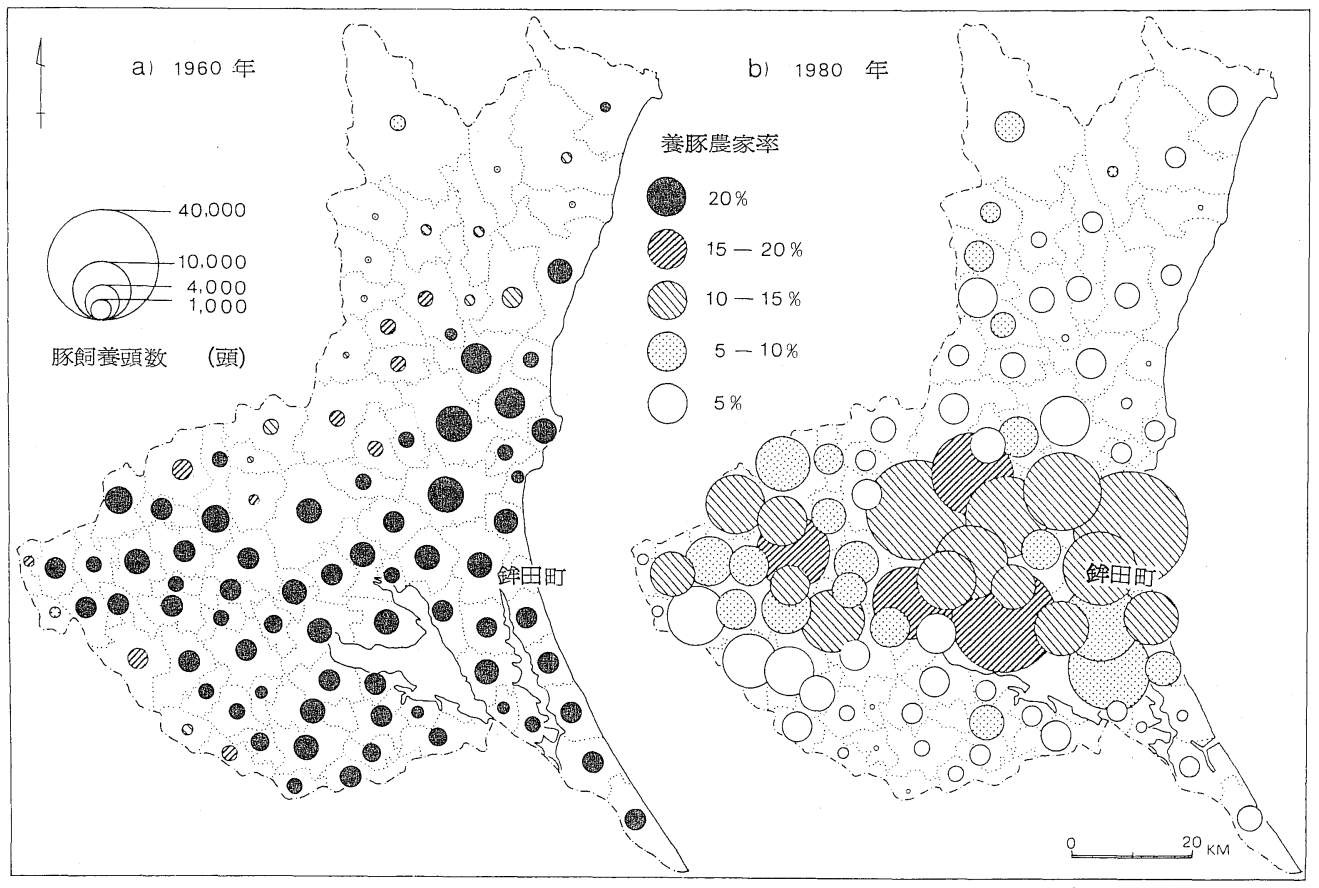

茨城県に打ける豚飼養頭数と養豚農家率の分布（1960 年，1980 年）(農林業センサスにより作成） 
第 2 次世界大戦後に打ける鉾田町の養豚業は, 1964 年ま で採肥や仔取りを目的とし, 米や麦類, 甘藷, 落花生など を生産する耕種部門の補完部門としての役割を担ってい た。その後, 周期的に変動する肉豚価格や豚の飼料となる 甘諸生産量の減少, さらに豚の䔬尿に代わる化学肥料の普 及から，零細・副業的養豚農家は淘汰された。また，1970 年頃から養豚農家は農家収入の大部分を養豚から得る肥育 経営や一貫経営と, そうでない繁殖経営とに分化してきた。 具体的な経営分化の過程を南野地区でみてみよう。

南野地区は洪積台地に立地し, 大部分の土地は林地や原 野の開拓による畑地であった。そのため, 農家は畑地を熟 畑化すべく有畜畑作農業を導入乙, その一環として, 採肥 と仔取り生産を目的にした養豚経営を行らようになった。 このような養豚の経営基盤は脆弱で零畑であり, 農業経営 に打ける養豚の地位は副次的なものであった。1965 年以降 になると，養豚農家は副次的養豚から主業的養豚に，さら に専業的養豚に発展するものと, 副次的養豚にとどまるも の, そして副次的養豚から畑作専業あるいは畑作兼業に移 行するものとに分化してきた。

専業的養豚農家は, 1982 年現在, 南野地区の農家全体の 約 20\%にあたる 14 戸で, 1975 年以降, 急速に増加した。こ の類型の農家は 1975 年頃まで繁殖と肥育を組合せた経営 形態であったが，農業後継者の確保，近代化施設資金によ る経営規模の拡大, 䨢尿処理場の設置, そして畑作部門の 縮小などにより経営基盤を確立させ, 肥育経営あるいは一 貫経営に移行してきた。豚飼養規模は 200 頭から 1,800 頭 で, 養豚収入は農家所得の $90 \%$ 以上を占めている。主業的 養豚農家は 7 戸で, 農家所得の約 70\%を養豚から, 残りを
甘藷やゴボウ, 落花生などの畑作から得ている。この類型 の農家では, 世帯主夫婦と後継者夫婦の 2 世代が農業に従 事し，50頭から 200 頭の豚が飼養されている。また，この 類型の農家は 1965 年頃から現われ, 繁殖と肥育を組合せた 経営を行っているが，䔬尿処理場にできる広い耕地を所有 しているため, 資本の蓄積をまって専業的養豚経営に移行 する可能性が高い。つまり，主業的養豚農家は専業的養豚 農家に移行する過渡的段階といえる。

副次的養豚農家は 18 戸で, 畑作や養虫に養豚を組合せた 複合経営を世帯主夫婦だけで行っている。この類型の農家 は採肥や仔取りを目的に 1 頭から 50 頭の繁殖豚を飼養し ている。しかし, 養豚収入は農家所得の $40 \%$ 以下であり, このような経営形態は 1965 年以前のものと変りなく, 周期 的な肉豚価格の変動に対する抵抗力や市場での競争力に欠 けている。したがって，肉豚価格の暴落を契機に，養豚を 中止する農家が現われている。そのような農家のなかで, 耕 地規模が大きく, 農業後継者が確保できた農家はメロン生 産を主体とする畑作専業農家に, また耕地規模が小さく, 農 業後継者が確保できない農家は畑作兼業農家になっていく のである。

以上のように, 養豚経営の分化は, 農業後継者の有無々 養豚技術や経営能力, 扣よび資本の蓄積や調達にみられる 農家間の差異に起因していた。しかし，南野地区の養豚業 は，農家が台地上に分散し，糞尿処理場に転換できる広い 耕地を団地として所有していること, さらに㽰豚農家が畑 作専業農家に䔬尿を供給する関係を維持していることなど に支光られ，発展している。

\section{東北地方に和ける農村の変容}

横 田忠夫（山梨大）
発表者は 1962 年以降葉たばこ栽培の地域的盛衰を通じ てわが国農業の地域的变容を 20 年にわたって追跡調查し てきた。

東北地方は古くから福島県, 岩手県南部, 山形県東根地 方などのたばこ産地として知られる地域を持った地方で あったが，今日わが国たばこ生産に揖ける比重は以前より 増して重いものとなってきている。

それは，今日たばこ栽培面積が全国比で 32.5\%（1981 年), 稲作農家 $42 \%$ といら数字でも示されるし, かつ 1962 年当時の面積が約 $20 \%$ であったことからいってもその生 産地としての重要性はますます抬大しているといらことが でさる。
しかし，局地的にみるとその盛衰は変化に富み，なかに は衰退の著しい地域も少なくない。

葉たばこ栽培の盛衰はこの地方の農業の葉たばこ栽培専 業化, 逆に他作物栽培の発展等に起因するわけであるが, ま た近時の兼業化の著しい発展が農業そのものの衰退とな り, 当然葉たばこ栽培も衰退している場合もありうる。

この地方での最近 20 年間に葉たばこ栽培がもっとも発 展した地域は岩手県北部から, 青森県十和田市周辺にかけ ての地方であって, 旧来の米・雑穀作・畜産の経営にバ一 レー種が導入され，それが競合作物のテンサイ，果樹・豆 類などにらちかち，かつ米の生産調整等の条件も加わって 発展したものであり，栽培農家の一戸当り栽培面積も大き 
く, 葉たばこ栽培と米作を基幹とした専業農家が多くをし める。

しかし，なかには廃作してニンニク，ナガイモ栽培に転 じたもの, 出稼ぎ主体化, 兼業化したもの汪どあって, 栽 培戸数は減少しながら栽培面積が増大している点に特色が ある。

一方, 衰退または衰退傾向にある産地は古くからの産地 に多い。なかでも戦前まで集中的葉たばこ産地として知ら れた秋田県南部の増田地方や岩手県水沢周辺部などの衰退 が著しいが, 前者は果樹園化, 後者は開田化によるたばこ 耕作直地の減少に起因するところが大きい。

旧産地でも岩手県千廦, 大迫, 山形県東根地方は今日で も面積は大きく主産地の地位を保っているが, 廃作農家も 多数生じて抢り, 全体としては衰退傾向にあるといってよ い。
これは多くが山間部や扇状地にあって農地に之しく, 従 来の耕作より大反別の耕作に適するようになったたばこ作 を，経営維持して行くことができなくなった農家が生じた 結果による。また，東根地区は近くに工場団地や山形空港 ができ, 後継者夫婦が農外就業につくのが普通となったこ とに起因している。

このように東北の農村を葉たばこ盛衰の動向を指標とし てみていくと,この 20 年間に大きな変容をとげていること を知りらる。

それは東北地方が今日も全国的には米，葉たばこ等の農 産物の主産地となってはいるが，都市化・工業化の波をう けた農村の農業衰退, 山地農村での脱農, 離村化の拡大な ど全国的な傾向がこの地方でも徐々に進行しつつあるこ と, また， 1 集落の中でも専業化，脱農化という明確な分化 が進行しつつあることを示している。

\section{十勝岳連峰南西麓に打ける傾斜地農業と農地保全}

—とくに麓郷を中心として——

早 船 元 峰（駒沢大）

\section{1 目的}

十勝溶結凝灰岩からなる波状性の台地の傾斜畑は, 敗戦 後集中豪雨による土壤流亡害が発生した。1953 年より農地 保全事業が実施されたが，今日それの施設 (工法的) や農 法はまったく見られない。しかしここ数年来画期的ともい える急傾斜畑面そのものを緩傾斜化するいわゆる大規模な 人工の地形改変が進められているが, 保全上問題点も多い。 そこで戦後から最近をでの傾斜地農業と農地保全との関 係を, 農法的, 工法的, 営農的面から考察していく。

\section{2 資 料}

傾斜地農業の変化 (土地所有, 土地利用の変化) 等を又 るため, 各時代の空中写真, 地形図, 農家台帳, 自作農創 設地分割実測図，林班図等をもとに図化した。土壤侵食の 発生した畑扣よび最近均平化した畑（その実施前と後）の 地形断面図を実測により作成し，検討した。

3 結果

戦前から 1952 年の集中豪雨による大流亡害頃までは縦 畧が一般的であった。その理由として土壤侵食に対する無 感心, 幸いにして 1952 年まで大流亡害がなかったこと, 急 傾斜畑ではかえって作業しやすい面があること, 畧間の土 壤は流亡されやすいが作物は流されずに済むといった土壤 よりも作物を大事にしていたことなどがあげられる。

1953 年より農地保全事業が実施され，テラス捕水路の設 置（高度差 $10 \mathrm{~m}$ ごとに等高線にそって被草水路をもうけ，
牧草を入れて有畜経営化し, あわせて有機物による土壤改 良をはかった）により等高線帯状耕作がなされ，畧は波状 性の畑では湾曲した形となった。しかし数年も経ずしてテ ラスは撤去され，等高線帯状耕作はすたれていった。この 原因として，(1) 小さな屈曲のある畑面では畧を水平につ くるのに相当の技術を要したこと，(2) 孫畧ができてわず らわしいこと, (3) 時の経過とともに保全の意識が薄れて きたこと，(4)施設による壊地率が数\%に拉よび不経済な 存在に思えてきたこと, (5) 機械化に邪魔であること等々 があげられる。

高度経済成長期以来, 自動耕うん機, トラクターの普及 をみ, 作付の単純化, 輪作期間の短縮化がはかられ, 無畜 化 (専営化) や化学肥料の多用などにより地力の低下を招 いてきた。さらに作付区が大型方形化され, 畧は地割, 道 路に沿った直線鲗となった。この畧は空中写真(1977 年)で みると整然としているが, 地形 (起伏) とは無関係となり, 斜畧, 縦畧の出現となった。また機械作業が危険でかつ土 地生産性, 労働生産性ともに低い急傾斜畑はカラマッ造林 に変化し, 期せずして結果的には保全上好ましい土地利用 となった（離農，離村が進及残留農家は隣接畑を買入れる ことで機械化にあわせた経営規模の拡大をはかり, 造林化 の余裕ができた)。

今日の営農をみると融雪から作物の葉の繁る前の 4 5 月と収穫から根雪までの 10１1月には台地の頂部から斜 
面下部までの傾斜畑が全くの裸地となり，保全の観点から 戦慄を扝ぽえる程の景観を呈する所も多い。栽培期間や植 物被覆度の季節別変化が似た作物(ビート, バレイショ, ニ ンジン，タマネギ）が多く作付され，上述の時期にはテラ ス，グリーンベルトが設けられていないため斜面長が 200 $\mathrm{m}$ をこえることもある。グスタフソンによれば流速の増加 にともなら侵食力の増大はその流速の自乗に比例すると報 告して扣り, 何よりも流去水の速度と水量を減じる方法が とられなければならない。

つまり今日の営農は機械化, 省力化を急ぐあまり, 平地 の農法をそのまを傾斜地へ適用し，それが保全上の問題を 抱劣たまま進行している。

しかしごく最近，一部の所で従来からの保全の工法とは 異なり, 畑面の勾配そのものを緩やかにする勾配修正工が 実施され始めてきた。これは大型機械による作業一貫体系
をはかるのが第一義の目的である。斜面の一部を緩傾斜化 (数度以下) することは, 逆に急傾斜 (盛土, 切土法面) を 新たにつくることでもあり, 過度の修正は法面の崩壞や土 石流の発生の危険がある等, 環境全体からみると現段階で は必ずしも安全とはいえない。

土壤侵食は自然災害 (天災) であると一般的に考学がち であるが，その原因を誘因と素因に分けてみると誘因は集 中豪雨という自然現象であるが, 素因は急傾斜, 受食性の 土壤という地形的, 地質的要因の他は, 先述のごとく営農 上の不適切さ (人為的) を数多くあげることができ,さら には 1952 年の流亡害は当時麓郷は演習林の小作地であり, 20 度をこえる所も農耕適地として農地貸下され, 造林は不 許可であったなど, 過耕地化といった社会的素因もあげら れるなど人災としてとらえる必要がある。

\title{
ブナ帯山村に和ける生業の変遷と土地・山林資源利用の空間的変化 ——栃木県栗山村土呂部の事例——
}

\author{
斎藤功（筑波大）。山本充（筑波大・院）
}

\section{1 目的}

山村に掞いては，耕域ばかりでなく耕地をとりまく山域 の多様な資源利用が, 集落存続の不可欠の条件であった。そ れは，山林資源に強く依存した木地師・狩椫。製炭集落等 のみに妥当するものではなく, 山村全般に妥当するもので あろら。しかし, 山村に和ける生業の, 特に農業の変化の 考察はしても，それと山林資源の空間的利用を関連させて 考察した事例は多いとはいえない。本報告では，山村に拉 ける生業と山林の生物資源の利用が空間的にどのような関 係を持っていたかを，栃木県塩谷郡栗山村土呂部を事例に 時代的に考察した。土呂部は, 鬼怒川の源流部に位置し,ブ ナ。ミズナラ林に囲まれたブナ帯の山村ということができ る。

\section{2 万法}

詳細な聴きとり調查によった。その際, 個別農林家の経 営耕地・家族構成等が記載されている土地台帳, 森林の所 有面積と番地が個人別・共有地別に記載されている森林簿 および森林施業図 (栗山村提供) 等で対照した。土地利用 の状況は数年来の観察と現地調査によった。

\section{3 結果}

栗山村土呂部に扮ける土地・山林資源の利用は, 宅地, 耕 地, 採草地・私有地, 国有林という同心円的配列を示した。 それぞれの利用状況を戦前と戦後で比較すると資源利用強 度に大きな差異が生じていることが明らかになった。
住宅域は江戸時代から成立した旧家層 7 軒を中心に，分 家が順次土呂部川の下流に成立することによって拡大し た。茅莫直家からトタン莫き等に変化し, かつて雑穀の調 理等に不可欠であった囲炉裏は消失した。

耕域はバレイショ一夏ソバーヒエ・アワーオオムギ一秋 ソバといら 3 年 5 作から, 戦後高度成長期に夏ダイコンが 導入されモノカルチャーへ変わった。しかし, 堆肥を投入 してダイコンの連作障害を少くするため戦前の馬に代えて 和牛が導入された。和牛の多頭育化はダイコンの副作にエ ン麦の栽培を, また畜舎の耕域への進出 (Aussiedlung)を もたらした。

耕域の周囲に採草地がある。採草地は畑に投入する青草, 馬の飼料, 萱場, 炭俵の原料供給源として多面的に活用さ れた。残存する採草地は八ギ・チガヤ等からなり, 黒毛和 牛の冬季飼料として活用されている。一方, 採草地を含め 共有地の私有地への分割が行なわ机たが，その配分は旧家 層に厚く，新戸に薄いといら傾斜方式で実施された。この ような傾斜配分は採草地ばかりでなく, 私有林, 耕地所有 にも認められる。採草地の広狭は, 和牛飼育規模に対応し, ダイコン栽培面積とも有機的に結合しているので, 社会構 造を反映したものといえる。しかし，採草地・私有林の利 用強度は, 山桑や大麻採集の消隇, 茅莫き屋根の減少等に より低下している。

採草地・私有林の外側に国有林が拡がる。国有林はかつ 


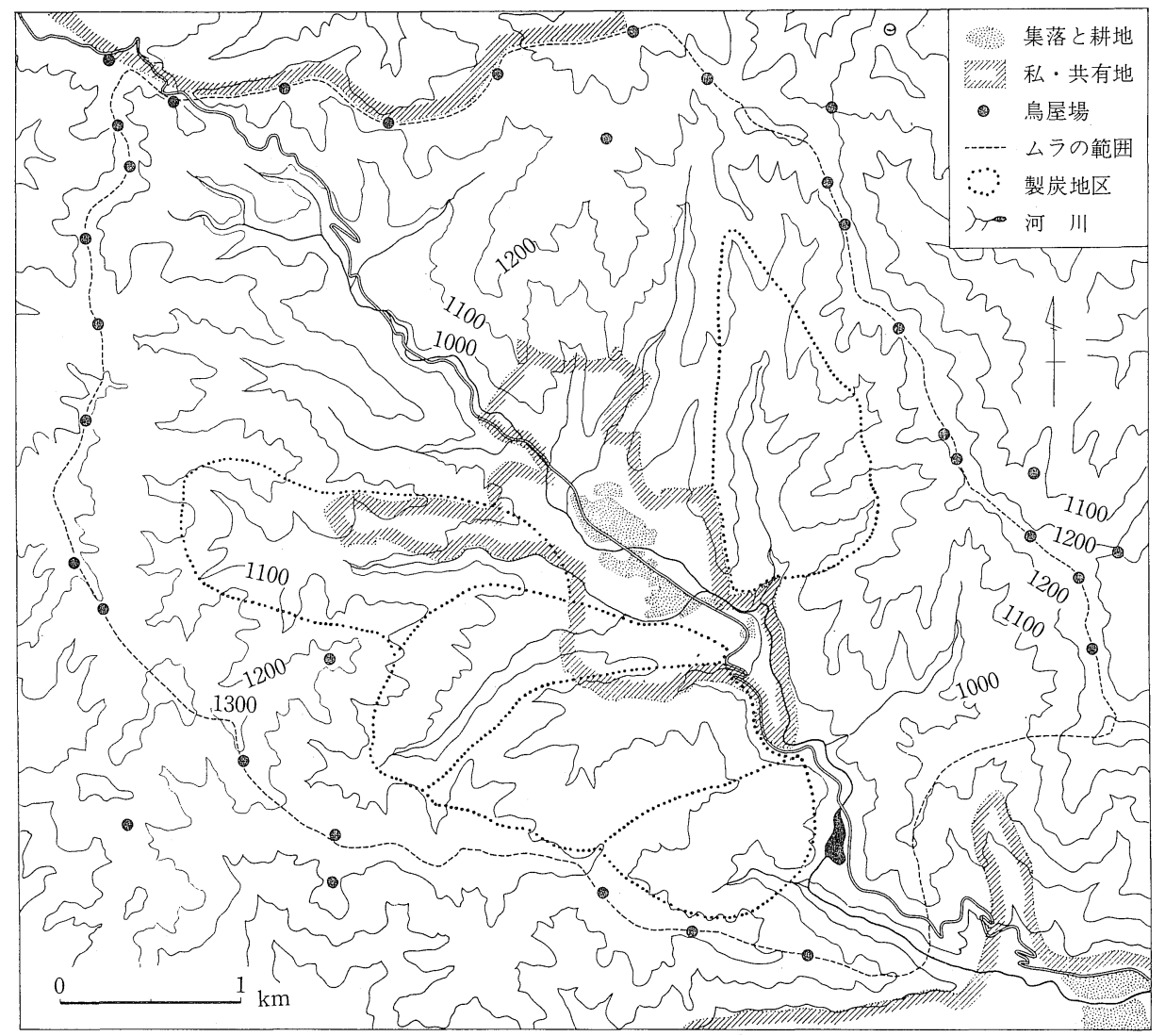

土呂部周辺の国有林利用（聞き取りによる）

て栗材の日光膳の素地挽き, クロビを使った日光曲物の素 地割り、トチ材の木鉢等を製作する舞台であった。さらに バンドリ (ムササビ) 猟やッグミ・アトリ猟に, また歩合 制の製炭にも国有林は活用された。戦後の燃料革命まで続 いたブナ材の製炭も衰退し，ッグミ㺂とサンショウウオ漁 が近年まで行われてきた。今日，土呂部の範用内にある国 有林の利用は，夏季に和牛を放牧する牧場のみになり，国
有林利用強度は著しく低下した。

以上のように冬季間に行なってきた山仕事が終りをつ げ，村民は余剰労働力を農外就労に振り向けざるをえなく なった。人夫・日雇などの季節的不安定就労であったが，ダ ム・林道・道路工事の増大により, 通年兼業化した。若者 の中には恒常的勤務も増えてきた。

\title{
丘陵地に打ける自然環境の空間的構造をとらえる試み
}

\section{（1）丘陵地の自然環境とその保全・開発をめぐる諸問題}

\author{
田 村 俊 和（東北大）・武 内 和 彦（都立大）
}

1 自然環境の空間的構造

都市地域など, 各種の開発が著しい地域でも, 自然環境 を保全する必要のあることが唱えられるようになっている
が，それを具体化していくには，さまざまなスケールの土 地利用計画，とくに地区計画拈よびそれ以下のレベルの計 画の中に, 環境保全策を適切に組み込むことが必要である。 
それに対する “計画" の側と “自然”の側との両方からの アプローチが行なわれるべきであるが, 自然の側からは, 自 然環境を構成する諸要素の現実の空間的分布を小地形〜微 地形スケールで調ベ, 各要素間の相互関係を明らかにした 上で, 各要素のからみあいかたで特徵づけられる, 各スケー ルの “環境地域”とも言らべき空間単位をとらえることが 有効々考兄られる。それを基に, 中心的に保全すべき範囲 やそれに隣接する影響範囲などが，現実空間の中に設定で きるからである。このよらな，言わば自然環境の空間的構 造を，とくに小地形一微地形スケールで明らかにすること は, さらに，視覚的にとらえられる事象の空間的分布を通 じて (非視覚的要素をも含む) 自然環境全体の空間的構造 を洞察するという, 手法を整備するための基礎論ともなる。 2 調査対象とする自然環境の一類型としての丘陵地の 特性

「(近年の) 開発が著しく, それに伴って自然環境の保全 が唱えられるようになった地域」の 1 つの類型として, こ こでは丘陵地をとりあげる。その主な理由は, 以下に述べ る丘陵地の自然的特性, その上に展開した土地利用の変遷 史，そしてそれらを媒介する社会経済的・技術的状況に求 められる。

日本列島に和ける丘陵地の, 中地形・小地形スケールで の地形・地質特性とその発達史, 小地形・微地形スケール での地形・土壤の形成・維持過程と水文現象，扣よび植生 などについては，演者らがすでに論じている（田村 (1974) 東北地理 26-4 ; 田村 (1977) 土木工学大系 19 巻; Tamura and Takeuchi (1980) Geogr. Rep. Tokyo Metropol. Univ. No. 14/15; Tamura (1981) Sci. Rep. Tohoku Univ. Ser. 7 31-2 ; 武内 (1983) 地理 28-6 など)。

3 丘陵地の土地利用パターンとその変化

丘陵地を構成する小地形 (丘頂緩斜面, 丘腹斜面, 小段丘 面，丘麓緩斜面，谷底面など）が，台地や低地の小地形よ りも一般に小規模で, 空間的にも複雑に入り組んでいるこ とは, 従来, そこに都市的土地利用や連続的な農地あるい は大植林地が展開することを阻んできた。さらにそれを, 一
般に傾斜地を嫌う日本の集落の伝統的立地傾向が, 助長し ていた。その結果丘陵地は, 狭い谷底面の水田々, 小段丘 面・丘麓緩斜面（および丘頂緩斜面の一部）の畑地，なら びにその中に点在する小農業集落を除き, 広く二次林に覆 われてきた。

1950 年代後半からのいわゆる燃料革命は, 二次林の社会 経済的意義を低下させる一方, 都市の膨張がその周囲の(主 として低地・台地に展開していた）農地の地価の高騰を引 き起こした。こうして 1960 年代からのいわゆる高度成長期 には, 都市近郊の丘陵地は, 以前にも増して, 隣接する低 地・台地に比べて利用価值の低い土地とみなされ, 顕著な 相対的低地価地帯を形成していた。一方, 主として新第三 系一下部更新統の半固結堆積岩から成り起伏のあまり大き くないという，中地形スケールの地形・地質特性をるつ丘 陵地は, 同じく 1960 年頃からの大型土木機械の急速な普及 により,むしろ人工平均化の容易な土地自然類型とみなさ れるようになった。このようにして全国各地で, 丘陵地の 小地形〜微地形スケールの自然の特性を消去することを前 提とした大規模宅地開発が，1960年代から爆発的に行なわ れるよらになったのである(田村ほか(1983)地理評 56-4)。 これはまた，二次的な自然の残片（二次林に覆われた未改 変の丘陵斜面）に接した人工的な土地に大量の都市住民が 居住するといら，日本では未曾有の事態を出現させるもの でもあった。

4 人工改変地にとり巻かれた丘陵地に和ける自然環境 保全の視点

上述のような状況にある丘陵地の, 決して自然度の高く ない（かつてはどこにでもあった）“自然”を，都市的土地 利用の一部あるいはそれに隣接するものとして, 保存・活 用していくための視点を確立する必要が生じてきた。それ を得るために，冒頭に述べたよらな，言わばカテナの概念 を若干拡張したようなものを明らかにしていく方法が有効 であると考光，それに立脚した事例研究を仙台南郊高館丘 陵と東京西郊多摩丘陵のそれぞれ一角で展開したのが，こ れに続く 5 つの発表である。

\title{
丘陵地に扔ける自然環境の空間的構造をとら兄る試み
}

(2) 高館丘陵，中の沢地区の地形々土壌

\author{
宮 城 豊 彦 (東北学院大) ・田村俊 和 (東北大)
}

仙台付近には, 新第三系からなる丘陵地が広く, 仙台駅 を中心とする半径 $20 \mathrm{~km}$ 圏内では, その $60 \%$ 強の面積を 占める。この丘陵地は大規模宅地開発に利用され，著しい 人工改変をらけているが, 仙台都心から南へ10２0 km に
ある高館丘陵は自然の地形が良く残っている。

標題の地区は, 集水面積 $0.74 \mathrm{~km}^{2}$ の, 細かに開析された 4 次水流の流域であり, 同丘陵中 西部の緩斜面卓越地域 から東部の急斜面卓越地域への移行帯に位置する。その基 
岩は，主に中新統高館層の安山岩質熔岩㘧よび凝灰角礫岩 で構成される。

この流域の地形について, 空中写真判読と現地補足調査 を行って, Tamura $(1980,1981) の$ Multiscale Landform Classification による小〜微地形の集合として理解し,ささ にその一部について, 微地形スケールで, 地形・土壌のや や詳細な調査を行い, 地形学図を作成した。さらにこの図 をMorphometrical に補足するため斜面測量器 (TRS-20) による地形断面実測を行い, あわせて土壤断面の観察も 行った。

以下, 詳細な調査地域にみられる微地形単位の地形・土壤 の特徵と, これら徽地形単位の成因よりもむしろ現在の機 能について推論し, それらの空間的配列の規則性について 述べる。

1 各微地形単位の特徵々地表面安定度

1) 頂部平坦面：稜線上の平坦な地形で, 傾斜数度以下。 堆積面起源の丘頂部に普通だが，ここでは削剝性で土壤は 薄く乾いている。

2）頂部斜面：稜線上にみられる凸型緩傾斜部で，多く は $15^{\circ}$ 以下。1）と同様に, 削剝性と堆積面起源とがあり, ここでは前者のみ存在する。4 個所の試抗では, いずれもや や截頭傾向にある残積成の断面が観察され，これらは，適 潤性褐色森林土(偏乾亜型)に対比されると思われるが，下 層で赤味が強い。またやせ尾根上では特に $\mathrm{A}$ 層が薄く, 削 剥が相対的に強いことをしめす。1）も含めて，ここでは， 土壤匍行等により微量の剝脱があるが高い地表面安定度を 保つ。ただし縁辺部は稀に，4＜wide>６）の崩壊により削られる ことがある。

3）丘脚先端斜面：2）の縦断方向の傾斜が増し, 谷部に 傾き下がる先端部。水や地質の動きは盛んだが, 発散的で, 土壌は薄く乾いていることが多い。所によっては残積成土 層の截頭断面の上位に, $20 \sim 30 \mathrm{~cm}$ の匍行・崩積成 $\mathrm{A}$ 層を伴 う場合もある。

4）上部谷壁斜面：3）以外で，2）下方と次に述べる 5) の両微地形単位と遷急線で区切られる。断面形からして, 水・物質の移動傾向は発散的であるとは思われないが，3） に似た土壤の性質を持つ。3）4）は，やはり削剥傾向にあ るが，截頭されると同時に斜面上方からの移動物質により 覆れることもあり，土層は，2）等よりわずかに厚い。

5）下部谷壁斜面：4）と以下に述べる各微地形単位と の間の急斜面で, 匍行成母材からなる土壌は概して薄く, 崩 壊跡などに基岩が露出する。

6）谷頭急斜面：平面形が半円状となる谷上流端の急斜
面で，谷が分水界へ向けて伸長する最先端に位置する。土 壌はごくらすく，A/C 型の断面を持つことが多い。5）・6) では，斜面上方からの物質供給があるが，この位置での削 剝が盛んなため土層は薄く未熟であり, 移動・削剝様式は, 土壤匍行だけでなく表層崩壊も含む。水路以外で, 地表が 最も不安定な微地形単位である。

7）谷頭凹地一谷頭平底：6）直下で, 谷型の地形である が水路を欠く部分。下流方向への傾斜は数度 $30^{\circ}$ 程度ま で多様である。概して土㙴は厚く，B層までで厚さが $1 \mathrm{~m}$ を越すことも珍らしくない。埋没 $\mathrm{A}$ 層や木炭片も含まれる ことがあり, 累積成をしめす。周囲の各微地形単位 2)，4） 〜6) からもたらされる物質の堆積の場であるが, 谷型綐断 面の上端に位置するため下流への物質供給の場でもある。 この土層自体でゆっくり斛行していると思われ，その安定 度は，8）頭部に和ける崩壊の発生と対応しているとみて 良い。

8）水路：7）下流側で突然出現する。上端付近では，7） の物質が再崩壊・再堆積し厚い土層を作る。水流による活 発な侵食・堆積の場であり, 物質の移動速度は丘陵地で最 大である。土壌はしばしば欠如している。

9）麓部斜面：5）の脚部に出現することのあるやや凹 形の緩斜面。沖積錐・崖錐的なものと, 削剝性のものがあ る。堆積性の斜面は, 概して厚く累積成の土壤断面をしめ し，その安定度は5）斜面の活動度によって決まる。

10）谷底面：8）に沿って出現する明らかに流水の作用 で形成された地形で，段丘化した部分も伴う。洪水時の土 砂堆積・運搬の場であると同時に側方侵食の場でもあり地 表面は不安定であるが，多少とも段丘化した場所では高い 安定度を得る。また降雨の際に土壤水は, しばしば飽和す る。

2 微地形単位の配例

以上述べた本地域の微地形単位は基本的に次のような順 に配列している。

1）尾根型縦断面（稜線をたどり，最後に谷に落ちる）： 1）または2）一〈遷急線〉一2）一〈遷急線〉一3）一〈遷緩線〉 $-9)-10)-8$ )。

2）谷型縦断面：1）または 2)一〈遷急線〉一6）一〈遷緩 線〉一7）-〈遷急線〉-8）-8,10）一〈遷換線〉一沖積錐性 の9）一〈遷緩線または潮移〉一主流路沿いの9，１0）。

3）横断面(谷頭部以外)：1）または 2)一〈遷急線〉一4) 一〈遷急線〉一 - 5) 一〈遷緩線〉一-9) 杂たは 10) - 8) 一(以下 逆順)。 


\section{丘陵地に和ける自然環境の空間的構造をとら省試み}

(3) 高館丘陵, 中の沢地区の植生

菊 池 多賀夫（東北大）

本研究は, 丘陵地の半自然植生域で, 植物群落の組成の 調查を微地形単位ごとに実施し, 植物群落の類型単位と微 地形単位との対応関係の把握をめざしたものである。微地 形スケールの地表の変化は, 植物群落の立地として重要な 意味を持っており，両者の結びつきを指標とした地域区分 は, 自然環境の分布様式を研究する上で重要な課題と考え られる。

調査地に卓越する植物群落は，胸高直径 $15 \sim 20 \mathrm{~cm}$,樹高 $10 \mathrm{~m}$ 前後の落葉樹の森林で, いわゆる雑木林にあたる。一 般にコナラが優占するので以下コナラ林と呼ぶ。調査でと りあげられた微地形単位は, 頂部斜面, 谷頭凹地（谷頭平 底を含む)，上部谷壁斜面，下部谷壁斜面，丘脚先端斜面， 麓部斜面, 谷底面（低水路底を含む）である。調査対象の 植分（個々の調査区が設定された植物群落）を，これらの 微地形単位の範囲を越えないように選び，組成を主とした 群落調查を行った。その資料から植分間の組成的類似度を Jaccard の類似度指数によって計算し，Bray-Curtis 序列 法に従ってすべての植分を直線座標上に位置づけた。すな わち, もっとも類似度の低い 2 植分を両極とする座標軸を 定め, この 2 植分に対する類似度に従って他のすべての植 分の位置を座標上に与えた。その位置に従って, 植分間に 序列が生じたことになる

この序列に従って, 各植分が立地としている微地形単位 を見ると, 頂部斜面, 丘脚先端斜面, 上部谷壁斜面の 3 微 地形単位が一方の極に 1 群をなし, 次いで下部谷壁斜面, 麓 部斜面が位置し, さらに谷頭凹地, そして他方の極には谷 底面が位置する。植分の序列は種の存在の類似性にの夕依 るものであるが, 立地としての微地形単位も, その序列に 対応してこのように配置される。

頂部斜面，丘脚先端斜面，上部谷壁斜面の植分には，コ シアブラ, アオハダ, リョウブ, ツクバネ, マルバカクミ ノスノキ, ナガバノコウヤボウキ, ヒメカンスゲ, アズマス
ゲなどが特異的に出現し，それを指標にして他の微地形単 位上に成立する植分と区別できる。しかしこれら３微地形 単位間で，それぞれに立地する植分の組成上の相違を認め ることはできなかった。その限りで，これらは森林に対す る立地としては同質と認められた。一方, 下部谷壁斜面, 麓 部斜面では上記の種群が欠ける反面, シラヤマギク, カノ ッメソウ, ヤブレガサ, ノダケ等の出現が特異的であった。 これらはすべて草本植物であるのに対し, 上記種群の多く は森林の中間層, 低木層の木本植分で, 両者の対照はきわ だっている。

一方, コナラ, クリ, カスミザクラ, ホウノキ等, コナ ラ林の林冠部を構成する種群は, 頂部斜面, 丘脚先端斜面, 上部谷壁斜面のみならず下部谷壁斜面，麓部斜面すで普遍 的に出現する。注がマッッジ，コゴメウッギ，ッノハ シバミ，アキノキリンソウなど，雑木林に基本的な多くの 種も同様に分布する。従って上記の 5 つの微地形単位は, 少 くとも林冠に主眼を扮いて見たときのコナラ林の立地とし ては基本的に同質であるが，林床の構成種にとっては，前 3 者と後 2 者との間にあきらかな相違が認められることに なる。

谷頭凹地と谷底面では, 一般に，林冠が発達しない。そ のうちで, 谷頭凹地には, アズマネザサ, チゴユリ, ムラ サキシキブ，才オバクロモジ，ツリバナ，七カゲスゲ，モ シジハグマ, オセリハグマ等, コナラ林にも普遍的な低木, 草本植物, 掞よびシラヤマギク，カノッメソウ，ヤブレザ サ等, 下部谷壁斜面, 麓部斜面之共通の草本植物が生育す る。これらの種群は谷底面には出現しないので, 谷頭凹地 と谷底面には, 植物群落の立地として明らかな相違がある。 後者にはヤブデマリ，タマブキ，ウマノミッバなどが出現 する傾向が認められるが，この立地への特異的結びつきは 明暸ではない。 
丘陵地に括ける自然環境の空間的構造をとらえる試み

（4）高館丘陵，中の沢地区の土歵花粉

$$
\text { 三 浦 修（東北大） }
$$

土壤断面を直接花粉分析の対象とした研究は, 国外に若 干の例はあるものの，国内には殆んどない。その理由はつ ぎの 2 点にあると考㝋られる。(1) 土壤発達過程での腐植 の変質, 土壤生物活動, 土壤水の運動などによって, 花粉 粒の保存の悪さあるいは層位的な乱れが当然問題となる。 (2) 土壤試料採取地は多くの場合, 森林等の密な植被域であ る。そのため, 花粉組成には局地的な植生が直接的に反映 する。この 2 点に関し, 演者の研究例によって検討すると, （1）土壤花粉も層位的に扱い得ること，(2) むしろ局地性は 具体的林分のスケールの問題にアプローチし得ること, が 結論づけられる。研究例はブナ林帯上部に限られているの
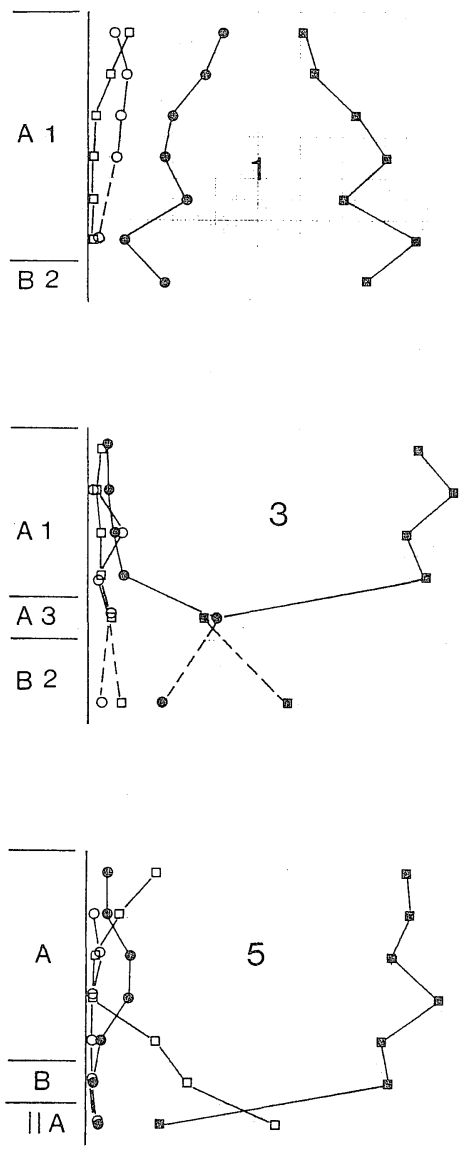
発表の主目的である。
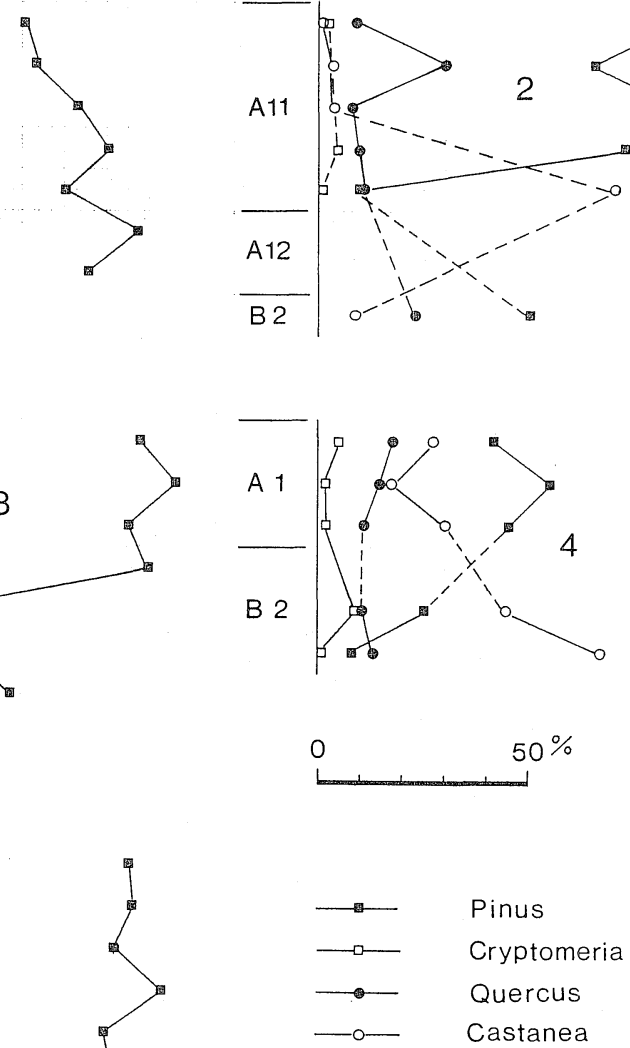

で, 土壤もいわゆるモル型の腐植層をものに限られていた。 そこで，今回は，ょり低海拔域でしかもコナラ二次林下の ムル型土壤を, 同様の手法でみてみようとした。これが本

試料採取地点は, 共同研究者の地形分類を考慮して, 頂 部斜面から水路底面へのシリーズ上に置いた。花粉粒は, 土 壤断面でほぼ $\mathrm{B}$ 層上部のみに, 組成を求めるに十分な保存 が認められたが, 下層は胞子のみが検出されたにすぎない。 主要樹木花粉のみ組成を図に示す。

結果を以下箇条書きにして列挙する。

1）全体に優勢な花粉型はマッ属である。

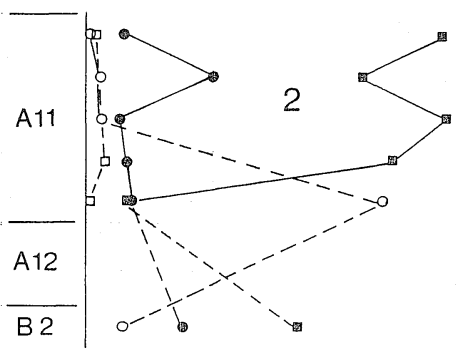

主要樹木花粉のダイアグラム

頻度は全樹木花粉型総数を基準とする 
2）下層へ胞子の出現率が高まる。

3）すべての地点で，上層と下層で花粉組成に差異がみ られる。その差異の程度や質 (差を生ずる花粉型) には地 点ごとの共通な花粉型は明確には認められない。

4）下層でキク科，ヨモギ属が若干高率となる。

5) 地点 1 (頂部斜面) と地点 5 (水路底) の層位的組成 変動はやや小さく, その間の地点 (谷壁斜面) では, クリ

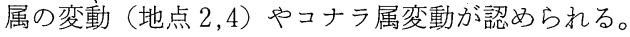

以上は全体を通じての特徵であるが，地点ごとのものは 以下のようである。

6）地点 $1,2,4,5$ で上層でややコナラ属が高率となる。

7）地点 2 の深さ $15 \mathrm{~cm}$ Horizonでクリ属はピークを つくる。

8）地点 4 では, 他と比べて, コナラ属, クリ属が高率 で推移する。

9）地点 4 で, アブラナ科, オカトラノオ属の高率ピー

クの Horizons がみられる。

10）地点 5 ではスギ属が他と比べて高率である。

11）地点 5 では上層にマメ科が高率でみられる。

以上の結果の考察であるが，明確な結論は引きだすこと
はできなかった。以下推測の域をでないことをことわりの 上検討してみた。

谷壁斜面上でみられるクリ属とコナラ属の変動による上 層と下層の差異は, コナラ林の伐採を示すのか子知れない。 地点 2,4 のクリ属の高率は, 現在のコナラ林の構成からみ て, 伐採後のコナラ林の発達過程の local な event を示す。 コナラ林が発達してきたことはコナラ属の上層への増加傾 向によっても裏付けられる。

最後に土壤発達あるいは表層物質移動の編年上の問題に ついて, 土壤花粉分析からの可能性について若干検討する。

マッ属は, 現在のアカマッ林の分布からみて, 地域全体 に一様の降下していると考光てよい。マッ属の減少 Horizon が local な事情を反映し，それが，地点間で注ぼ同時期 と仮定すれば, その深さは, 地点 1 から地点 5 へ増してい る。これは定性的な地形観測から予想されることと一致し ている。

土壤花粉分析の有利な点は, 湿原や湖沼を探しまわる必 要はない。いわばどこでもやれる。地形研究者の望む場で, 表層の営力問題へのアプローチをあるいは支援できそうで ある。

丘陵地に和ける自然環境の空間的構造をとらえる試み

（5）高館丘陵，中の沢地区にみられる地形，土壤，植生の空間的対応関係

田 村 俊 和（東北大）

(2)で明らかにしたよらに，この地区では 10 種類の微地 形単位が確認される。土壤は，抢そらく母材の影響で，あ まり顕著な分化を示さないが，風化断面下記の岩片に富む 層位の出現する深さ，斜面上方から匍行等の作用で，また 上流から流水により，運搬されてきた被覆物質の厚さ，沶 よび土壤水分などに注目すると, 地表付近に打ける現在の 土壤物質や水分の移動状況，すなわち地表面安定度が，推 測される。この地表面安定度の傾向は，(4) に報告された土 壤花粉の出現状況からも一部裏付けられる。一方植生に関 しては，(3) に述べられたよらに，注ぽ全域を覆らコナラの 優先する雑木林が, 4 つの林分群に分けられる。これらの調 查結果を，微地形単位の基本的配列を示す模式図にあわせ て表示すると，下記のようになる。

このような整理を通じて,「地形・土壤・植生なぞ土地自 然を構成する各要素の空間的分布状況は, 完全に一対一に 対応するものではないが，その配列パターンには強い類似 性があること」, 拈よび「各要素のらちでは微地形が最も明 確な空間的分化を示すこと」が明らかになった。したがっ て, 少なくとも今回の調查地のような丘陵地では, 微地形 に注目して地表面を区分することが，地形・土壤・植生招

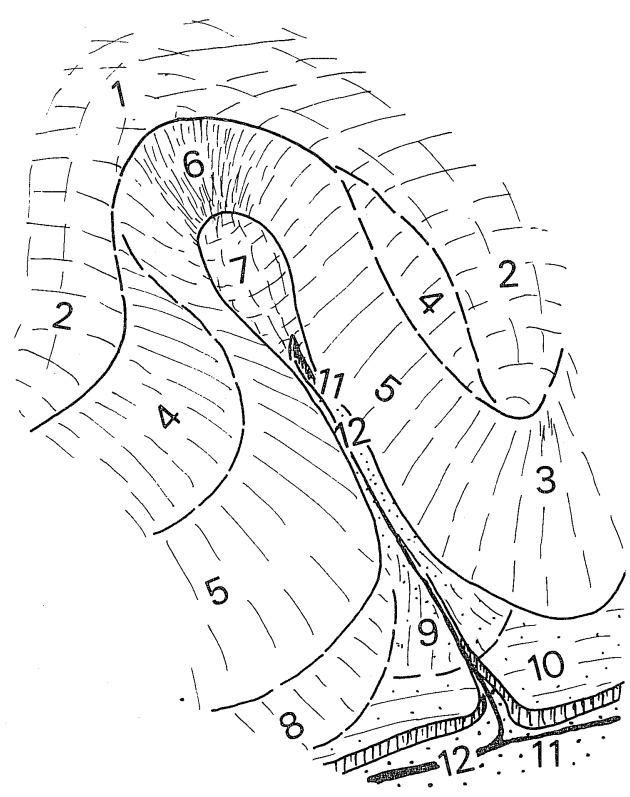

高館丘陵, 中の沢地区にみられる微地形単位 


\begin{tabular}{|c|c|c|c|c|c|c|c|c|}
\hline 微地形単位 & 柾 & & & & 地表面安定度 & 土 & 壤 & \\
\hline & 〔共 通 種〕 & 〔林 元 & 冠〕 & 〔林 床〕 & & 〔型〕 & 〔厚き〕水分 & 状況了 \\
\hline $\begin{array}{l}\text { 1. 頂部平坦面 } \\
\text { Crest flat }\end{array}$ & ウワミズザクラ & & コシアブラ & $\begin{array}{l}\text { シラヤマギク } \\
\text { 等 }\end{array}$ & $\begin{array}{l}\text { 高 } \\
\text { (弱い削剝) }\end{array}$ & 適 & 薄 & \\
\hline $\begin{array}{l}2 \text {. 頂部斜面 } \\
\text { Crest slope }\end{array}$ & (高木) & コナラ & アオハダ & アズマネザサ & $\begin{array}{l}\text { 中 } \\
\text { (削剝) }\end{array}$ & $\begin{array}{l}\text { (一部 } \\
\text { 偏乾亜型) }\end{array}$ & $\begin{array}{l}\text { とくに } \\
\text { 薄 }\end{array}$ & \\
\hline $\begin{array}{l}3 . \text { 丘脚先端斜面 } \\
\text { Nose }\end{array}$ & $\begin{array}{l}\text { アオキ } \\
\text { (低木) }\end{array}$ & クリ & リュウブ & & $\begin{array}{l}\text { 中 } \\
\text { (通過·削剝) }\end{array}$ & 潤 & 薄 & $\begin{array}{l}\text { やや } \\
\text { 乾 }\end{array}$ \\
\hline $\begin{array}{l}4 \text {. 上部谷壁斜面 } \\
\text { Upper side slope }\end{array}$ & コバノギボウシ & $\begin{array}{l}\text { カスミ } \\
\text { ザクラ }\end{array}$ & 等 & ムラサキシキブ & $\begin{array}{l}\text { 中 } \\
\text { (通過・削剝) }\end{array}$ & 型 & 薄 & 乾 \\
\hline $\begin{array}{l}\text { 5. 下部谷壁斜面 } \\
\text { Lower side slope }\end{array}$ & (草本) & 等 & & $\begin{array}{l}\text { シラヤマギク } \\
\text { 等 }\end{array}$ & $\begin{array}{l}\text { 低 } \\
(\text { 削剝·通過) }\end{array}$ & & $\begin{array}{l}\text { とくに } \\
\text { 薄 }\end{array}$ & 中 \\
\hline $\begin{array}{l}\text { 6. 谷頭急斜面 } \\
\text { Headmost wall }\end{array}$ & $\begin{array}{l}\text { トリアシショウマ } \\
\text { (草本) }\end{array}$ & & （欠） & チゴユリ & $\begin{array}{l}\text { 低 } \\
\text { (強い削剝, } \\
\text { 小崩壊） }\end{array}$ & $\begin{array}{l}\text { 褐 (あるいは } \\
\text { 未熟土) }\end{array}$ & $\begin{array}{l}\varepsilon<に \\
\text { 薄 }\end{array}$ & 中 \\
\hline $\begin{array}{l}7 . \text { 谷頭凹地 } \\
\text { (谷頭平底を含む) } \\
\text { Head hollow }\end{array}$ & $\begin{array}{l}\text { フジ } \\
(つ る)\end{array}$ & （欠） & & $\begin{array}{l}\text { シラヤマギク } \\
\text { 等 }\end{array}$ & $\begin{array}{l}\text { やや低 } \\
\text { (堆積・通過 } \\
\text { 含小崩壊) }\end{array}$ & 色 & 厚 & $\begin{array}{l}\text { やゃ } \\
\text { 湿 }\end{array}$ \\
\hline $\begin{array}{l}8 \text {. 麓部斜面 } \\
\text { (一部崖錐に覆われる) } \\
\text { Footslope (Talus) }\end{array}$ & 等 & $\begin{array}{l}\text { コナラ } \\
\text { クリ } \\
\text { 等 }\end{array}$ & & 等 & $\begin{array}{l}\text { やゃ低 } \\
\text { (堆積) }\end{array}$ & 森 & 厚 & $\begin{array}{l}\text { やゃ } \\
\text { 湿 }\end{array}$ \\
\hline $\begin{array}{l}\text { (9) 麓部斜面（沖積錐） } \\
\text { Footslope (Alluvial cone) }\end{array}$ & & & & ヤブデマリ & $\begin{array}{l}\text { 低 } \\
\text { (堆積) }\end{array}$ & 林 & 厚 & 湿 \\
\hline $\begin{array}{l}\text { (10)谷底面（小段丘化） } \\
\text { Bottomland（Terraced） }\end{array}$ & & (欠) & & タマブキ & $\begin{array}{l}\text { やや低 } \\
\text { (堆積) }\end{array}$ & & 厚 & 湿 \\
\hline $\begin{array}{l}\text { 11. 谷底面 } \\
\text { Bottomland }\end{array}$ & & & & 等 & $\begin{array}{l}\text { 低 } \\
\text { (堆積·侵食) }\end{array}$ & $\begin{array}{l}\text { 土 (一部 } \\
\text { 未熟土) }\end{array}$ & 厚 & 湿 \\
\hline $\begin{array}{l}\text { 12. 水路 } \\
\text { Channelway }\end{array}$ & & & & & $\begin{array}{l}\text { とくに低 } \\
\text { (通過, 線的 } \\
\text { 侵食） }\end{array}$ & （未熟土） & $\begin{array}{l}と<に \\
\text { 厚 }\end{array}$ & 湿 \\
\hline
\end{tabular}

よびそれらをとりもつ水や土壌物質の移動状況など，地表 付近の自然環境の空間的展開を統一的にとらえる上で，有

効であると言觉る。

丘陵地に打ける自然環境の空間的構造をとらえる試み

（6）多摩丘陵西部に扣忊る自然環境要因の相互関係

武内 和 彦（都立大）

大規模土地改変を伴う住宅地開発の進行が著しい多摩丘 陵西部を例に，自然環境保全型住宅地開発技法を確立する ための基礎資料を提供する目的で，自然環境要因の空間的 相互関係の解明とそれを踏まえた複合的自然環境単位の設 定と空間配列のパターン化の可能性を検討した。

事例地区として，八王子ニュータウン予定地の一部を選 び, また比較対照の意味で, 多摩ニュータウン B4 地区に保 全された小流域を対象として，各専門家による自然環境総 合調查を実施した。調査の対象とした自然環境要因は，表 層地質, 地形, 水文, 土壤, 土壤動物, 植生, 鳥相である。

これらの調査結果をもとに, 図に示すよらな断面図をい くつか作成して, 自然環境要因の空間的相互関係について
の考察を行なった。その結果, 各自然環境要因は必ずしも 一義的な分布対応を示していないものの，それぞれの空間 的配列には一定の法則性があり，基盤となる説明要因とそ の上にある被説明要因は，一部人為的影響を強く受けたも のを除いて, 相互に密接な関係を有していると判断された。 自然環境要因の相互関係の概略は，つぎのようにまとめら れる。

1）透水層と難透水層の層序ならびに傾斜は，地下水を 中心とする水循環に支配的な影響を与克，また，谷地形の 発達とも深く関係している。八王子地区では, 2 層の粘土層 を基盤とした二重構造的な谷の発達が認められる。

2）土壤は, 微地形の配列に従って分布しており，八王 


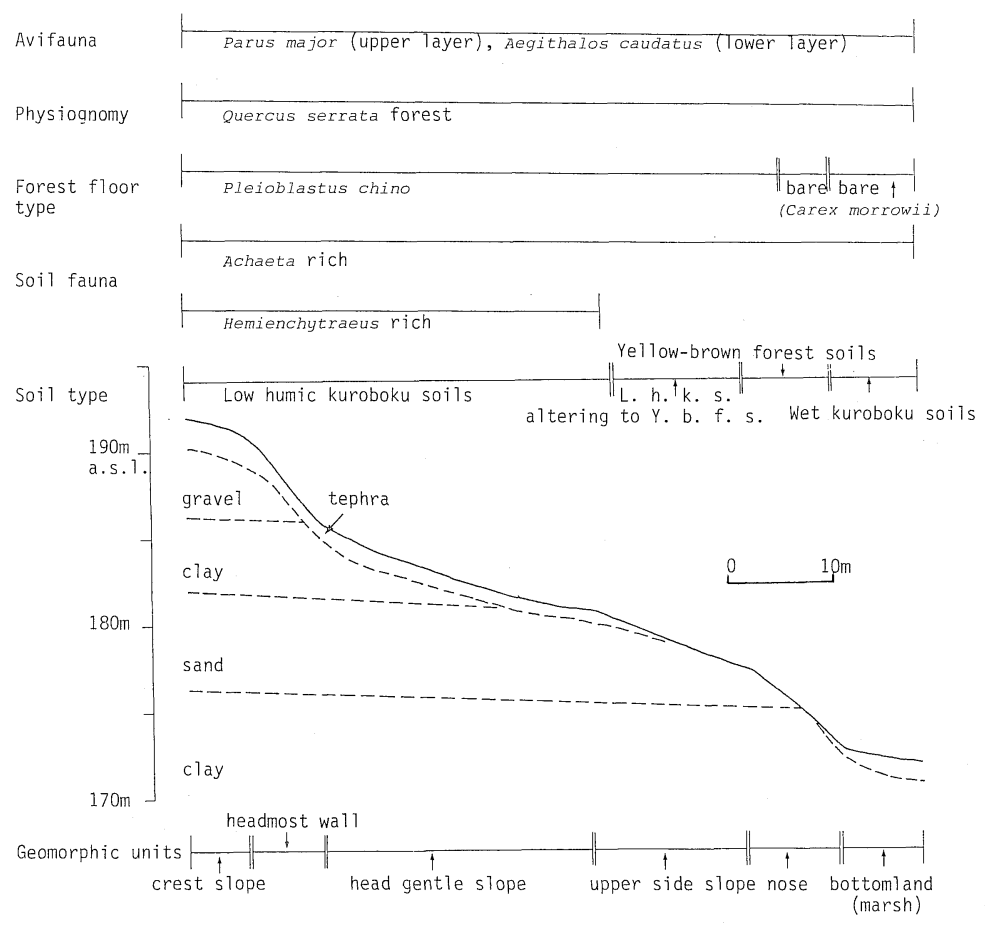

多摩丘陵八王子地区に括ける微地形スケールの自然環境要因の相互関係

子地区では, 頂部平坦面から丘脚先端斜面に至る尾根型断 面上で, 黑ボク土, 淡色黒ボク土, 淡色黑ボク土一黄褐色 森林土，黄褐色森林土と順に就きかわり，また，谷頭急斜 面から谷頭凹地を経て谷底面に至る谷型断面で，崩積性黒 ボク土, 多湿黒ボク土, 黒ボクグライ土, グライ土と連続 的に変化している。一方, 多摩 B4 地区では, 火山灰層が厚 く堆積して抢り，尾根型断面上には黒ボク土がよりひろく 分布する。

3）土壤動物については，ヒメミミズ科の各属と土壤と の間に一定の関係が認められた。すなわち, Achaeta は表 層の腐植含量が少くち密な八王子地区に多く, Hemienchytraeus は固くて水分の多いこの地区の淡色黒ボク土に 多くみられた。交た, Fridericia は表層の C/N 比がやや高 い多摩 B4 地区の黒ボク土に多かった。

4）植生は，八王子地区の場合，人為的影響に基づく単 純化が進行して, 相観的には大部分がコナラ林で覆れるが,
林床優占型には地表の水分状況に対応した差異が認められ る。すなわち, 乾性立地から湿性立地にかけてアズマネザ サ，ミゾシダ，カンスゲが順に優占している。また，表層 の不安定な丘脚先端斜面上には，傾倒木や根まがり木が多 く又られ, 林床植生はみられない。多摩 B4 地区の場合には 相観植生にも差があり, 頂部斜面上部にアカマッ林, 谷底 面にハンノキ林やヨシ草地が分布する。

5）鳥相は，八王子地区のみ調査されたが，コナラ林域 での分布の偏在は見出せなかった。ただし，垂直的には，上 層と下層で，それぞれエナガ，シジュウカラが多くみられ るといら棲み分けは認められた。

このような調査結果から, 説明要因と被説明要因がほぼ 連続的につらなり，そうした自然環境要因の相互関係を踏 まえた複合的自然環境単位の設定と空間配列のパターン化 は十分可能であると判断された。 


\title{
暖温帯に招ける常緑広葉樹二次林の分布について
}

\author{
磯 谷 達 宏（都立大・院）
}

従来わが国の二次林植生の生態学的・地理学的研究は, 自 然林植生の研究と比較してたら遅れていたが，近年全国的 に植物社会学的な植生研究・植生図化が進展したことによ り，二次林植生の広域における地域性を検討することが可 能になりつつある。伊藤・川里（1978）は全国的規模で二 次林の和もな植生型の分布を交とめたが,これによると, 暖 温帯に打いて，自然林と類似した相観をもつ常緑広葉樹二 次林 (シイーカシ萌芽林) が, 海洋性の強い地域を中心に 分布している現象が注目される。そこで，暖温帯に括ける 常緑広葉樹二次林の分布とその成立要因々の対応関係につ いて，若干の考察を試みた。

これまでの植物社会学的な二次林研究の多くでは, 二次 林の群落型は，打もに自然林の群落型との対応といら視点 から位置づけられてきた。しかしながら，暖温帯における 二次林植生の広域的な分布を調ベると，群系レベルに扔い て顕著な地域分化が認められる。すなわち, 常緑広葉樹型 の二次林（シイーカシ萌芽林など）が海洋性の強い地域を 中心に暖温帯をとりまくように分布しているのに対し，常 緑針葉樹型の二次林（アカマッ林）は瀬戸内地方などの比 較的乾燥した地域を中心に分布して扔り，落葉広葉樹型の
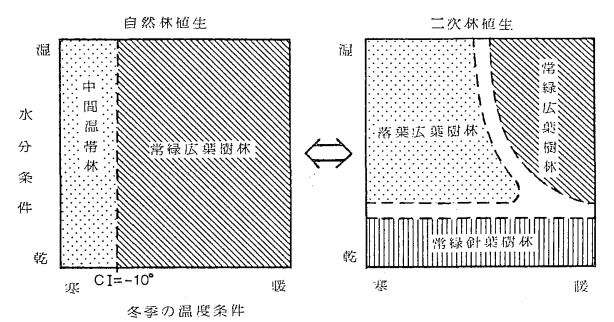

第 1 図暖温帯における自然林・二次林植性の配列模 式

(暖温帯: 暖かさの示数 WI が $85^{\circ} \sim 180^{\circ}$ の領 域)

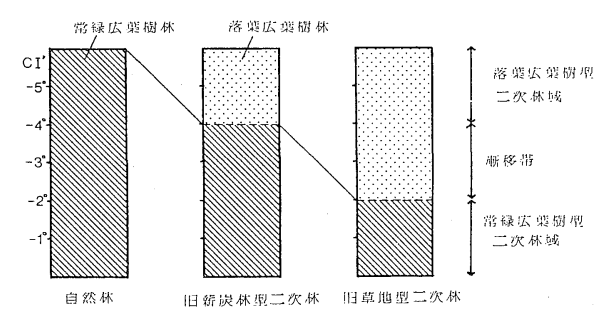

第 2 図南房総に拈ける二次林植生の配列模式 $\left(\mathrm{CI}^{\prime}\right.$ : 月平均気温 $\mathrm{t}=7^{\circ}$ 以下の月について 7-t の值を積算し,ーをつけた值)
二次林 (コナラ林) は，中間温帯など，内陸部の冷温帯へ の移行地帯を中心に分布している。そしてこのような地域 分化は，自然林には顕著な差として現われていない気候的 な立地の差異が人為作用という圧力の下で顕在化したため に生じたものと考党ることができる。

暖温帯に打ける常緑広葉樹型の自然林一いわゆる照葉樹 林は，世界的にみると，比較的温暖で水分条件にも十分恵 まれた立地を中心に分布して扣り，その北限は冬の寒さに よって規定されているものと考光られている。そこで，暖 温带に和いて自然林と類似した相観をもつ常緑広葉樹二次 林は, 常緑広葉樹の生育に本来最も適した立地 (冬季も比 較的温暖で，水分条件にも恵まれた立地）を中心に分布し ているものと考觉るとができる。

上記のような見解の正否を確かめるため, 南房総を事例 地域として, 常緑広葉樹二次林の分布とその成立要因との 対応関係を検討した。南房総は太平洋岸に打学常緑広葉 樹二次林の分布の北限域にあたるが，降水量は全般にわ たって暖温帯としては平均的な值を示している。したがっ て当地域に执いては，常緑広葉樹二次林の分布が冬の寒さ によって規定されているか否かが焦点となる。5万分の 1 の現存植生図に $500 \mathrm{~m} \times 500 \mathrm{~m}$ のメッシュをかけ，二次林 の植生型の分布を読みとると, 太平洋沿岸部を中心とした 常緑広葉樹型二次林（シイーカシ萌芽林）の分布帯・内陸 部を中心とした落葉広葉樹型二次林 (コナラ.林) の分布帯。 両者の漸移帯といったゾーンへの地域分化(メソスケール) が認められる。南房総の場合, 地質・土壤といった土地的 な要因については, メソスケールに揖いて二次林植生の相 観の違いを決定するような差異が見い出されないので, 成 立要因としては気候要因和よび人為作用が問題となる。

気候要因についていくつかの気候值や気候示数の分布を 検討した結果, 二次林の植生型の分布はやはり冬の寒さと の対応がよく, 常緑型と落葉型との漸移帯は, 寒さの示数 $\mathrm{CI}=0^{\circ}$ の線とよく一致している。しかし, 当地域の場合 $\mathrm{CI}=0^{\circ}$ の領域が広く, CI では常緑型から落葉型への移り変 わりを説明できない。そこで, 寒さの示数 CI の閾値の $5^{\circ}$ を $7^{\circ}$ に変えることによって得られた示数 $\mathrm{CI}^{\prime}$ を用いると, 冬 季でも温暖な領域ほど常緑広葉樹型の占める割合が大きい ことがわかる。人為作用については, 旧市町村別の広葉樹 林単位面積あたりの伐採量, 执よび明治初期に括ける草地 的土地利用について検討したが，ともに上記のような二次 林植生の地域分化を成立させる要因とは認められない。た だし，常緑型と落葉型との漸移帯に揖いて旧草地が落葉広 
葉樹型の二次林に対応している傾向が認められるが，この ような現象も, 気候的な成帯性の存在を示唆しているもの と考光られる。

以上のよらなことから, 南房総に打ける常緑広葉樹二次 林の分布は冬の寒さによって規定されているものと考学ら
れ, このことは, 暖温帯の常緑広葉樹二次林の分布につい ての上記の見解を支持している。今後は，立地の乾燥によ る限界域を含めたより広い領域に执いて, 常緑広葉樹二次 林の分布とその成立要因との対応関係を検討し，本報で示 された見解を検証していきたい。

\title{
陸羽地震（1896 年）時の地変と地籍図 秋田県仙北郡千畑村・千屋断層の例
}

\author{
今泉 俊 文 (都立大)・稲庭智子 (侏 リコー)・片平 博 文 (都立大)
}

\section{1 目的}

陸羽地震（マグニチュード 7.0）は，1896（明治 29）年, 秋田県東部奥羽山脈真昼岳直下を震源として発生した直下 型の地震である。この地震の時, 横手盆地東縁部や真昼岳 東方和賀谷沿いには顕著な地震断層が現われ, 大地は大さ く食い違った。横手盈地東縁部に現われた地震断層は，地 震直後に調査を行った山崎（1896）によって千屋断層とよ ばれた。その後, 松田ほか（1980）が，これを北から生保 内断層, 白岩断層, 太田断層, 千屋断層, の 4 つの主要断 層に分けて，それぞれの断層の位置や当時の地変の様子を 聞きとり調査を含め詳しく記載・図示した。

本研究の目的は, 千屋断層（秋田県仙北郡千畑村内）に ついて, 山崎 (1896) や松田ほか (1980) が記述した地変 の位置を地籍図で確かめ，これまで断層の位置がよくわか らなかった地区について,これを明らかにすることにある。 さらに陸羽地震以前から存在していた低断層崖の判読も試 みた。

\section{2 資 料}

地籍図は明治 20 年頃全国一斉に作られた。横手盆地では 1889，1890（明治 22，23）年頃に測量が㧍こなわれた（こ れを地籍図 (1) とする)。その後生じた地目や地割の変換, 変更は, 地籍図 (1) に付篦を貼りその内容が示されている。 これを地籍図 (2) とする。1923（大正 12）年，横手盈地で は，大規模構造改善事業が扣こなわれ，地割は大きく変わ り, ほぼ現在の姿となる。この事業にあわせて, 現在の土 地台帳図が作られた（これを地籍図（3）とする）。

地籍図 (1) は明らかに陸羽地震以前に作られたもので, 陸羽地震によって生じた地変の変位基準を与学るものであ る。同時に, この図から判読された崖が断層崖であるなら ば，それは陸羽地震以前に生じた低断層崖を示す。地籍図 （2）は，少なくとも1890（明治 23）年以降に地目や地割に 変化があったことを示している。そのよらな変化の時期を, 土地台帳の記載事項と照合してみると，付嘎によって地目 変換や地割の変更 (分筆・合筆) が示されているものには,
“...明治 29 年ヨリ五ケ年免租年期…” の記載があった。租 税免除の記載は, 時期から考えて, 打そらく, 陸羽地震に よって土地が著しく荒廃したためと考えられる。また付箋 が一定の地域 (ゾーン) に集中する場合，台帳に免租の記 載がなくとも，土地が著しく変化したのだから，やはりそ の原因は自然災害 (陸羽地震) によるものと判断した。地 籍図（3）には崖が明記されて扣り，地籍図 (2) と対照する と, 位置こそ多少のずれがあるものの, 地震で生じた崖が 明瞭に示されている。

3 方法

地籍図から崖・急傾地を判読する基準は以下のと抢りで ある(図参照)。

1）土地利用（地目）が同じで(例えば水田) あるにも かかわらず，ある地域(ゾーン)だけが周囲に比べ地割（面 積）がせまい場合。

2）地割は同じでも地目があるゾーンだけ著しく異なっ ている場合。例えば周囲が注とんど水田であるにもかかわ らず, 一部が烟地, 草地, 林地, 荒地となっている場合。

3）筆番号の配列が, 周囲に比べ, あるゾーンを境に著 しく不規則になっている場合。通常, 筆番号は測量手順に 従って付されることが多いから, 地形が平坦, もしくは単 純な傾斜なら, 規則的にならぶが, 地形的な障害（崖や急 斜面）があるところでは配列は変わりやすい。

以上の認定基準に従い, 地籍図 (1) から, 陸羽地震以前 に生じた低断層崖を, また, 地籍図（1）と（2), (3) の比較 により，陸羽地震時に生じた低断層崖 (撓曲崖)を判読し た。

結果は各地域（大字）ごとに低断層崖付近の微地形分類 とあわせて表現する。

4 結 果

1）真昼川左岸上村地区では比高 $1.6 \sim 2.0 \mathrm{~m}$ の低崖が 陸羽地震によって形成され, その南の比高 $2.5 \sim 3.5 \mathrm{~m}$ の低 崖は陸羽地震以前からすでに存在していたと推定される。

2）一丈木, 釜淵川では比高 2.5 3.5 m の低崖が陸羽地 
地割（面積）
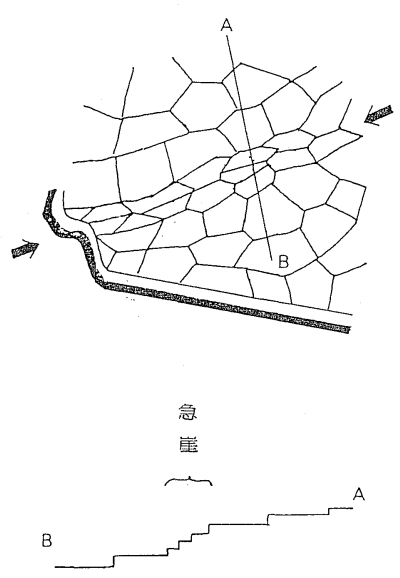

土地利用の違い

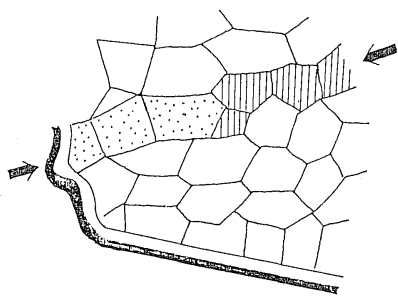

水田

$\because$ 蓂地

III]

崖・急傾斜の判読基準
筆番号の不規則狌
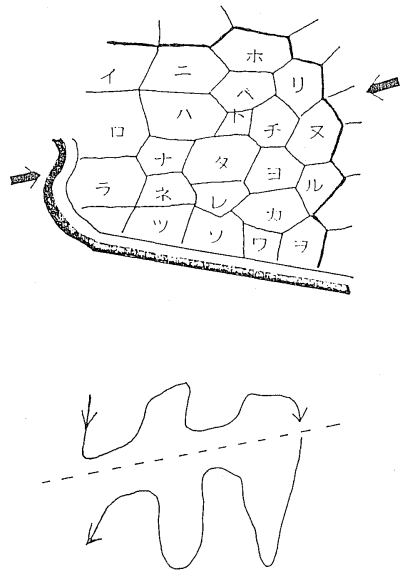

震によって形成されたことが，地籍図からよみとることが できる。

3）小森地区では谷底北半の低崖(比高約 $2 \mathrm{~m}$ ) は陸羽地
震により，南半のそれ(比高約 $4 \mathrm{~m}$ ) は陸羽地震以前にすで に形成された崖であることがわかった。

地域比較と境界設定の手法について

一北海道に拈ける土地利用を例として—

水見山 幸 夫（北海道教育大旭川分校）

ある地域をいくつかの小地域に分け，データを集計ある いは解析する場合，いかなる境界設定を行ならべきかとい 万問題は, aggregation problem と呼ばれる。これには, 各 小地域の構成単位間の空間的連続性を前提とする, zoning system に関する問題と, 連続性にはこだわらない, grouping system に関する問題が含なれる。このらち後者につい ては，クラスタ一分析法や主成分分析法の普及により，わ が国でも研究例が多いが, 前者については, 近年理論的研 究が増学てはいるものの, 適切な応用例に乏しく, わが国 に拈ける関心は必ずしも高くない。しかし, 従来の行政単 位毎の諸データに加壳, 近年, よりミクロな地域データや, 行政界によらないメッシュデータ等が急速に増大してお り，合理的な境界設定法の必要性が高まっている。そこで そのような手法の 1 つとして, 隣接する 2 万 5 千分 1 土地 利用図からなる系の, 単位地区 (各図幅) 内に括ける土地 利用項目別パーセントデータを用い, zoning を行なら手法 を考案した。
これはANOVA (Analysis of Variance) を基礎として 扣り, 次式で定義される zone(隣り合ら図幅のグループ)間 分散和の平方根 $\mathrm{T}_{\mathrm{B}}$ を, 系内の Z one 間差異の大小の指標 として用いている。

$$
\mathrm{T}_{\mathrm{B}}=\sqrt{\sum_{\mathrm{k}} \frac{1}{\mathrm{~m}-1}\left\{\sum \mathrm{n}_{\mathrm{i}}\left(\overline{\mathrm{X}}_{\mathrm{i} \cdot \mathrm{k}}-\overline{\mathrm{X}}_{\cdot \cdot \mathrm{k}}\right)^{2}\right\}}
$$

ここで $\mathrm{X}_{\mathrm{ijk}}$ は $\mathrm{i}$ 番目のZone 内の $\mathrm{j}$ 番目の図幅に打ける $\mathrm{k}$ 番目の土地利用項目のパーセント值であり, 添字の黒点の 印は平均值を表わす。また， $\mathrm{m}$ は系内のZ Z one 数, $\mathrm{n}_{\mathrm{i}}$ は $\mathrm{i}$ 番 目のzone 内の図幅数である。このように定義された $T_{\mathrm{B}}$ を, 考えられる種々の Zoning に対して算出し比較するこ とにより，いかなる Zoning が地域比較に有効であるかを 判断する。

この手法を北海道の石狩川流域とその周辺を含む24図 幅からなる系に適用した。図に示すように，各図幅には北 東端から順に番号を付し，その番号順に $3 つ(m=3)$ の zoneを設定する場合を考光た。その結果, 図中の A, B, C 

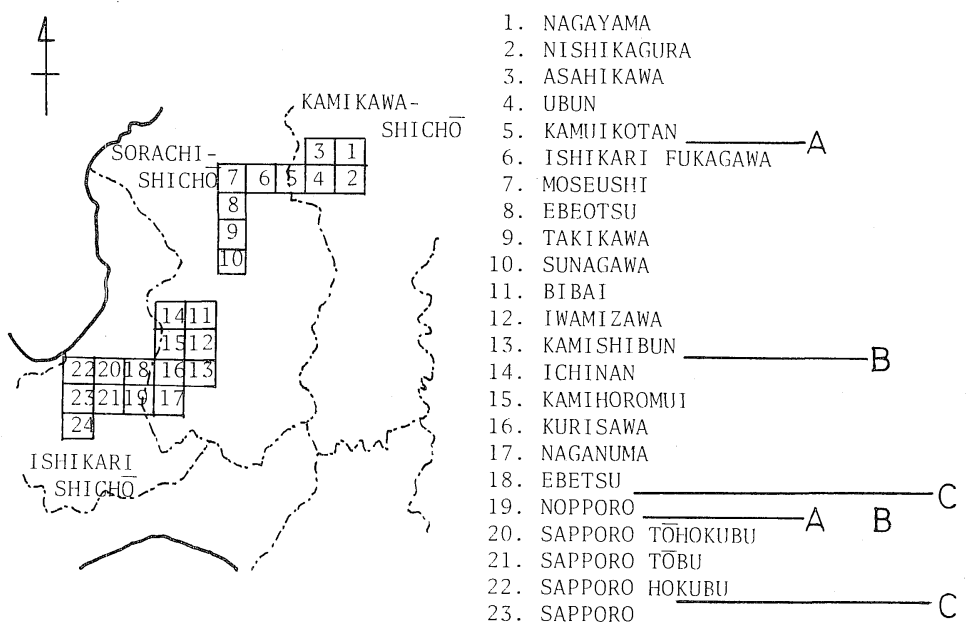

対照㘠幅の位置と zoning

A， B , C 3 通りの zoning の境界位置を示す

の 3 種の zoning が高い $\mathrm{T}_{\mathrm{B}}$ 值を示すことが明らかとなっ た。このらち例としてAの zoning について意義を検討す る。

Aの zoning の場合, zone 1 には上川盆地执よび上川盆 地と石狩平野の中間に位置する 1 からら 5 までの図幅が含ま れ，zone 2 には石狩平野中・北部に位置する 6 から 19 ま での図幅が含まれ，zone 3 には札幌市和よびその近傍の図 幅 20 から 24 までが含まれる。これらの3つのzoneはと れぞれ上川支庁, 空知支庁, 石狩支庁にほぼ対応するが, 土
地利用上も, 田の卓越する石狩平野中・北部，都市的土地 利用と普通畑・牧草地などのウェイトの高い札幌周辺, 両 者の平均をとったような上川盆地, といらょうに，差異が 明瞭である。

zoning が不適切であればこのような地域差が明瞭に現 われないことは論を待たない。上例ではたまたま zoning が行政単位とほぼ一致したが，このようなケースは多くは ないであろう。行政界にとらわれぬ合理的な Zoning 法に ついての研究の蓄積が緊要である。

\section{宮城県に和ける小売業よりみた市町村の階層システムの変容}

\section{石澤孝（東北大・院）}

大型店（大規模小売店舗）の出店やモータリゼーション の進行などにともなら商圏構造の変容はきわめて大きな研 究課題である。一般に, モータリゼーションの進行にとも なって消費者の移動が容易になるため商圏の競合が生じ, 高次な商品に関しては, より大きな町の商圏に組み込まれ ていく傾向がある。本論では, 大型店が出店することによ る，このような傾向の変化抢よびそれにともなら商圏構造 の変容について検討を試みる。資料として宮城県が 1978 年 と 1981 年に実施した商圈調査の結果を用いる。

宮城県に怙いては 1978 年までに, 県の南部地方を除く と, 11 市の他に迫町などの主要な町に一通り大型店の出店 がみられた。また，1978～81 年の間にも新たな大型店の出 店がみられ，店舗面積 $5000 \mathrm{~m}^{2}$ 以上の大型店のみをとりあ
げてもェスパル (仙台市), 泉 S.C. (泉市), 将監 S.C. (泉 市), 角田ファミリーデパート (角田市), 仙南 S.C. (柴田 町）が新たに出店した。また，この期間には県の南部地方 にも新たな大型店の出店がみられ, 亘理町や丸森町に大型 店が出店した。

まず, 大型店の出店に関して 1978 年以降顕著な変化をみ せた 6 市町 (石巻市, 泉市, 岩沼市, 柴田町, 丸森町, 亘 理町）について，3商品（紳士・婦人服，かばん，時計）に 関しての買物依存地区の変化について検討する。中央資本 の百貨店型の第 1 種大型店が出店した泉市, 柴田町, 亘理 町に拉いては紳士服・婦人服の地元への買物依存率が高 まっている。これに対して, 地元資本の大型店が出店した 岩沼市, 丸森町に就いては 3 商品とも地元への買物依存率 


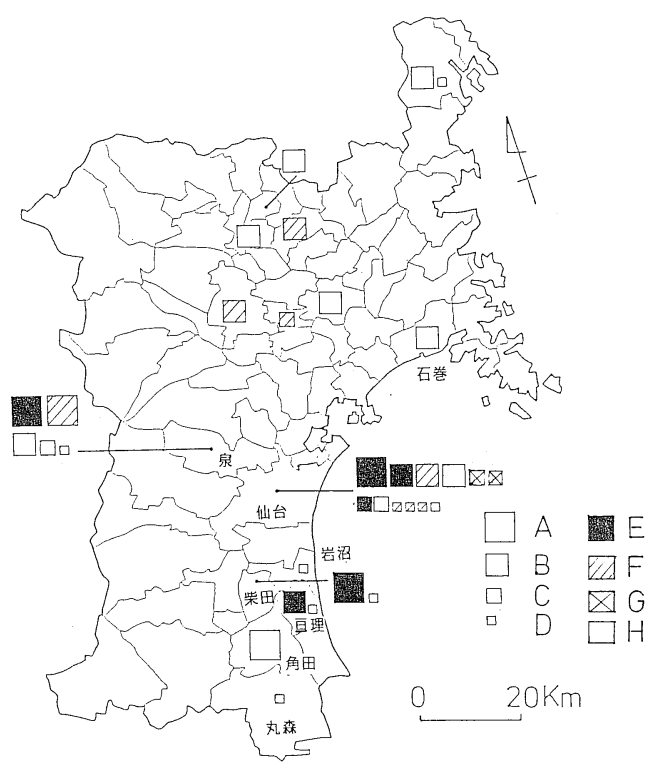

1978 年〜1981 年に出店した大規模小売店

A: $5000 \mathrm{~m}^{2}$ 以上 $B: 1500 \sim 5000 \mathrm{~m}^{2} \quad \mathrm{C}$ : $1000 \sim 1500 \mathrm{~m}^{2} \quad \mathrm{D}: 500 \sim 1000 \mathrm{~m}^{2} \mathrm{E}$ : 中央 資本型 $\mathrm{F}$ : 仙台資本型 $\mathrm{G}$ : 生協 $\mathrm{H}$ : 地 元資本型
が低下し，かわりに仙台市や角田市への買物依存が強まっ ている。また，仙台市に比べて大型店の集積の少ない石巻 市の場合も 3 商品とも地元への買物依存を弱め, 仙台市へ の買物依存を強めている。すなわち, 全体としては商圏の 競合により仙台市などのより大きな町の商圏に組みこまれ ていく傾向があるが，中央資本による百貨店型の大型店が 出店した場合には, 特定の商品について, このようなより 大さな町への消費者の流出をいく分なりかくいとめること が認められる。

次に, dyadic factor analysis 法により商圈を設定し, 商 圈構造の変容について検討する。特に高次商品の商圏に関 して商圏の競合が生じ，石巻市や一関市 (岩手県) のほぼ 中間に位置するために独自の商圈を有していた登米町や豊 里町の商圏が消滅した。また, 前述の岩沼市の商圏も仙台 市の商圏に組名込まれた。これに対して, 柴田町は独自の 商圈を維持している。このように, 全体としては商圈の競 合によりより単純な形の商圈構造に変容しつつあること が認められる。しかしながら前述の上らに，中央資本によ る百貨店型の大型店の出店により, このような傾向に変化 が生じることであるう。

\section{長野県の交通システムの評価}

荒 井良 雄 (信州大)

\section{1 目的}

地域の交通システムは社会・経済活動の基礎的条件をな し,そのシステムの適否は当該地域に大きな影響を及ぼす。 交通システムの変化が地域社会に与えるインパクトについ ては，すでに多くの事例が報告されているが，交通システ ムそのものの機能的な評価の手法については, 従来, あま り検討されていない。交通システムは，道路・鉄道等の線 的な交通手段がネットワークとして組み合され，さらにそ れが地域という面的な広がりと関係づけられなければなら ないため, 単純な数的表現によってその機能を記述するこ とが難しく，従来はネットワーク理論を用いた指標化（ $\alpha$ 係数， $\gamma$ 係数等)などが知られているに過ぎない。そこで今 回は, 長野県の道路ネットワークを事例とし, OR 的手法を 用いたシミュレーションを応用することによって, 交通シ ステムの機能を評価する手法の試みを行った。

\section{2 方法}

作業のための基本的な単位区画として標準地域メッシュ の 2 次メッシュ $(10 \mathrm{~km}$ メッュュ)をり，長野県を160区
画に分割する。評価対象とする主要地方道以上の道路から なる道路ネットワークを基本区画を 4 分割した区画を単位 として数值データ化する。この道路ネットワークデータに 対して道路種別毎に適当な速度パラメータを乗じてノード 間の所要時間を計算する。この結果に対してDijkstra 法を 適用することによって各区画間の最短時間を計算し，さら に同一基本区画内の 4 区画についての平均をとって最短時 間行列を算定する。次に, 地域の交通需要の分布を示すデー タとして人口（あるいは事業所数）をとり基本区画単位に 集計する。

上記 2 種のデータを組み合せると, 対象地域全域から特 定地点 (施設) へ到達するために必要な平均アクセス時間 を計算することができる。複数地点の場合は, 最近接地点 が選択されることを仮定して同様の計算を行うことがで き，それぞれの地点の勢力圏の推定も可能である。同様に して,アクセス時間別の累積人口曲線を求めることができ, アクセス条件の地域的格差を量的に検討することが可能に なる。さらに，平均アクセス時間を目的関数として適当な 
逐次計算を行うことによって総移動量を最小とする最も効 率の良い施設の配置 (最適配置) を求めることもできる。

3 高速道路網整備に伴らアクセス条件の変化

上記の手法を用いて，現在計画されている高速道路網整 備に伴って交通システムの機能の評価基準であるアクセス 条件がどのように変化するかを検討する。

県庁所在都市である長野までのアクセス条件を評価対象 とし, 平均刃クセス時間を指標にとってその変化をみると, 中央自動車道長野線開通の段階での変化が最も大きく, 平 均アクセス時間を $18 \%$ 短縮する効果がある。な和最終的に 関越自動車道上越線開通段階では一般道路のみの場合に対 して $33 \%$ の短縮となる。

東京圈へのアクセス条件を評価対象とした場合は, 現状 である中央自動車道西宮線開通の段階での変化が最も大き く, 前段階に比べて平均アクセス時間が $20 \%$ 短縮され, 最 終段階では一般道路の久の状態より $35 \%$ 短縮されること になる。

前者の長野へのアクセス条件の場合は，高速道路網の整 備が進むにつれて条件の地域格差が大きく，変化すること が特徵である。アクセス時間別累積人口曲線をるとにして, 上位 $25 \%$ の平均アクセス時間と下位 $25 \%$ のそれとの比(格 差指数 I）を用いて地域格差を指標化してみると, 中央道 長野線開通の段階で指数が 3.56 から 2.64 と一挙に低下 し，地域格差が大幅に解消されることを示している。一方， アクセス条件がより劣る地域の場合を下位 $5 \%$ の平均アク セス時間と $50 \%$ のそれとの比(格差指数 IV)でるると，中 央道西宮線開通の段階での格差縮小効果が大きく，その後
はむしろ徐々に格差が広がる傾向となっている。

以上を総合してみると，長野県の域内交通の面から考克 た場合, 中央道長野線の機能は特徵的であり, 長距離の拠 点間連絡といった高速道路のもともとの機能とはやや異な り，いわば中距離の地域間連絡とでも言らべき役割が期待 され，アクセス条件の地域格差是正につながりらると予測 される。このことは南北方向に長く, 北部と南部との接続 の問題が大きい長野県の地域的条件を反映していると考兄 られる。

\section{4 最適施設配置と地域区分}

上記と同様のデータを用いて，ある施設を利用しようと する場合の総移動量を最小とするような最適施設配置を求 めることができる。長野県内に 1 センター，2 センター, 4 センターをそれぞれ配置する場合を仮定して最適配置を求 めてみると, 高速道路網整備のいずれの段階でも結果に大 きな差は認められず，高速道路網の整備によっても公共施 設や企業の支店・営業所等の諸施設の配置に関する基本的 条件は大きく変化はしないものと思われる。

4 センタ一の場合の最適配置は長野県の一般的な地域区 分である東・南・中・北信の中心都市である上田・飯田・ 松本・長野の位置とよく一致し, その理論的勢力圏の境界 も現実の境界とほぼ一致することが見出せる。したがって， 4 中心都市を核とした 4 地域からなる地域のシステムは現 状の交通システムとよく整合して扬り，今後の高速道路網 整備によってもその体制に大きな変化は生じないものと考 えられる。

\section{北海道に和ける市街地分布体系の変遷 \\ 一一明治から現在まで——}

寺 谷亮 司（東北大・院）

本研究は, 明治以来 100 年にわたる北海道の市街地につ いて，その発生・分布・盛衰を時期別に把握することによっ て，北海道に打ける市街地分布体系の変遷を考察すること を目的とする。

対象市街地は, 明治以降, ほぼ 10 年間隔で設定した対象 年次に沶いて, 連担戸数が, 最低一度, 200 戸以上規模に達 した 591 市街地である。本研究では, 市街地機能に着目し, これらの市街地を「内陸市街地」, 「沿岸市街地」,「鉱山市 街地」,「衛星市街地」,「その他の市街地」の 5 類型に分類 した。

研究方法では，まず，順位規模曲線の推移から，市街地 全体の構造変化を検討した。次に, 各年次の市街地分布, 年
次間の市街地盛衰(規模順位の変化からみた相対的盛衰, お よび, 戸数变化率からみた絶対的盛衰)の特徵を, 分布図・ 集計表などによって，地域別・市街地規模別・市街地類型 別に把握し, 市街地の分布とその発展パターンを検討した。 その結果, 北海道の市街地分布体系は, 3 つの時期に大別 され，各時期の特徴は，以下のように要約される。

1) 明治 期

明治初期, 市街地は, 北海道南西部に偏在していたが, フ ロンティアが南西部から道東・道北へ, あるいは, 沿岸か ら内陸へと移動するに伴い, 道東・道北の拠点的市街地が 立地・発展をとげ，現在の市街地網の大枠が形成された。市 街地全体の構造変化では，これら拠点的な上位市街地への 
人口集中が特徵的であるといら点から, 集中化傾向が優勢 であった。最上位市街地は, 初期の函館・江差・松前が以 下の市街地を引き離す「蝦夷三湊」パターンから, 函館卓 越パターンへと変化した。

\section{2）大正 戦争直後期}

多数の内陸市街地が成立し, 市街地分布に和ける分散化 が進んだ。市街地盛衰では, 沿岸市街地の衰退, 内陸市街 地の発展が, 明瞭な地域的パターンとして展開された。た だし, 農業恐慌に起因する昭和初期の内陸市街地の低滞・ 衰退, あるいは, 戦時体制突入期の鉱山市街地の衰退など, 市街地盛衰は, 国内外の社会・経済情勢をダイレクトに反 映したものと解釈できる。最上位市街地は, 函館・小樽。 札幌の 3 市街地卓越パターンとなった。

3）高度経済成長期以後

大規模市街地が発展, 中小規模市街地が衰退するといら 規模による市街地の差別的発展がみられ, 市街地の集中化
傾向が強まった。市街地類型では, 鉱山市街地の衰退, 衛 星市街地の発展, 地域的には, 中心 8 都市周辺市街地の発 展が特徴的である。これらの点は, 市街地総数の減少, 大 規模市街地 ( 5,000 戸以上) の急増などと共に, 都市化の急 速な進展の結果と解釈できる。最上位市街地は, 札幌卓越 パターンとなった。

な㧍，本研究では，市街地機能については，汪と九ど言 及できなかったが, 各時期において, 市街地の成立・発展 をもたらしたと考兄られる主要市街地機能として，以下の ものを指摘したい。

1）明治期：開拓地域への入口としての Gateway 機 能。

2）大正～戦争直後期：農村中心としてのクリスターラ 一的な中心機能。

3）高度経済成長期以後：企業・官庁が集積し，以下の 市街地を管理・支配する集積・規模の経済機能。

\title{
衣川流域の水利と土地改良
}

\author{
阿 部 和 夫 (県立盛岡一高)
}

1 本研究は小河川流域に和ける土地改良が,どの上うな 時期に，ぞの上らな背景のもとに進められてきたかをさぐ るため, 事例を北上川支流の衣川流域に求めたものである。

2 岩手県に打故方地改良事業は, 明治末期に始まり大 正期に入って本格化している。衣川流域の場合は, 昭和初 期から戦時中にかけて個人事業が若干認められるけれど も，集団に上る事業は第二次大戦が終了するまでまったく 認められない。

3 土地改良事業は, 寒冷地型米作技術の完成による米生 産力の向上，食管法下に打ける米価の安定を背景にしてい ることは他地区の場合と同じである。衣川流域の農業は, 「自給的な米作」を基盤に「養亘」や「薪炭」などの現金収 入の獲得部門との組合せが伝統的な形態であるが，第二次 大戦後, 養亘・薪炭収入が拈ちこみ経営の再編成が必要と なった。土地改良の実施は新しい米作技術の適用のための, また経営再編成のための必須の条件とされた。

4 土地改良事業は, 昭和 20 年代に 1 事業 $82.2 \mathrm{ha}, 30$ 年 代に 10 事業 59.4 ha, 40 年代に 19 事業 322.1 ha, 50 年代 に 3 事業 171.0 ha がとりあげられ, 総計 33 事業 634.7 ha に及んでいる。米作の前提条件となる用水体系は, 衣川上
流の北股川から取水する北大堰，同じく南股川より取水す る南大堰など大小 8 つの用水堰によっているが，この原型 は江戸期に形成さ机たものである。戦前からの個人的な開 田, ならびに第二次大戦後の土地改良事業の進展は用水不 足を引き扢こし，用水堰の本格的な改修が必要となった。

5 流域最大の北大堰の県営改修工事は, 昭和 41 年から 7 カ年にわたってとりあげられた。事業は頭首工, 揚水機, 用水路の全面的な改修・新設が主なるのである。その完成 は周辺地区の同用水地区への編入を可能とし, 土地改良, 特 に開田事業の進展に大きなはずみをつけることになった。

6 土地改良事業は, 大幅な水田化之機械力の導入による 能率的な耕耘を可能とした。農業はこれを契機に米の単作 化傾向を強め,「商業的米作」を基盤に経営の改善が計られ た。米作に結びつく「 $\alpha$ 部門」として注目されるのは恒常 的な勤務の増加と商業的畑作や畜産の充実である。先に報 告した北上山地川井村小国地区の場合，土地改良事業が自 給主食の安定的な確保を基盤に畑地の商業的利用および林 業・建設業など農外労働との結びつきを強化するととるに， 生産性の低い畑地を休耕または生産放棄している。衣川流 域と小国地区はその点できわだった対象を示している。 


\section{日常語としての「都市」の成立}

羽田野正隆（北海道大）

都市という言葉は, 古くからある漢語であるが, 今日の 集落概念につながる用語としては, 明治以降わが国社会で 造られた漢語 (日本漢語) とみることもできる。この報告 では, 後者の観点から, その成立之定着について考光てみ たい。

1 江戸時代, 城下・府内・その他の名称で乎ばれていた 都市的集落は, 明治以降その呼称上のよりどころを失ない, それらに代わる名称が幕末一維新期の英和辞典や識者達に よる欧米視察記録を通じて模索された。

たと壳ば, 堀達之助編「英和対訳袖珍辞書」(文久 2 年, 1859)ではCity, Urbanをそれぞれ市街, 市街, と訳し, 日 本薩摩学生会編「和訳英辞書」(明治 2 年, 1869) では, 同 じく都府, 都府ノと訳している。また福沢諭吉「西洋事情」 （慶応 3 年，1864） は都府・都会用い, 久米邦武「米欧回 覽実記」（明治 11 年，1878）は主として都府（都市名には ○府）を用いている。他に都邑（太政官日誌滦か)，城市 (陸軍省地理図誌編輯布達), 輻輳地(共武政表活か), 都会 の地 (各書), 市街の地 (同)などの用例もあって, 明治初 期の都市的集落に対する呼称は多様である。明治 11(1878) 年の郡区町村編成法は都市的地域に区の呼称を与えたが, 東京・大阪・京都のように, 一つの都市が複数の区から構 成される例もあった。区は後の市をひきだした点に用語上 の意義がある。

2 明治 21 (1888) 年の市制・町村制の公布は都市といら 言葉の成立に何らかの契機を与えたのではないだろらか。 この点を同公布書（官報 1443 号）によって確めてみると, つぎの通りである。

まず，市制条文第一条に「此法律八市街地ニシテ郡/区 域二属也ス別二市卜為スノ地二施行スルモノトス」とあり, 市が市街もしくは市街地の略称として採用されたことが判 る。また同理由書に「区ノ名称＼cjkstart改メテ市ト為ス八三府, 如キ府内の区ト混同スルラ避タルナリ」とあって, 区を汪 添踏襲した新しい都市的地域化訓読及を共有する市をあて たことがらかがわれる。(市にマチとルビをふった例は明治 期に采れ見られる)
この法律は市の実質を規定したものであるから，都市と いら言葉は使われなくてもよい訳であるが，上諭の中に一 箇所だけ使われている点が注目される。すなわち「(上略) 法律 市制及町村制 裁可シテ之 である。当該箇所は都市でなければならない理由はないが, 一字ではイチと読まれる恐机があると判断されたのかもし れない。都市は新たに制定された市を語基（造語単位）と し，当時広く用いられていた都府を念頭に扔いて造られた と考光られる。ちなみに, 日本漢語のかなりのものは中国 語に取り入れられたが，都市がそのようにならなかったの は, 中国にはすでに城市といら言葉があったからであらう。

都市は古く漢書などに見られるし, 明治 10 年代にも田野 との対比で使われた例なども若干はある。けれども，その 実質的な原点は明治 21 (1888) 年の市制公布にあるとみる こともできょう。

3 都市は新しく生れた（見方により再生された）言葉で あるから、その普及には多くの時間を要したにちがいない。 実際, 市町村制に関わる解説書や新聞の論評を除けば, 明

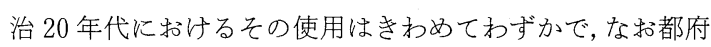
の方が多く用いられていた。明治 30 年代に入ると, 幸田露 伴「一国の首都」（明治 32３4 年, 1899 1901) の上5に, 都市・都府・都会を混用した例も市るが，概して歴史家・ 地理学者・文学者には, 都府・都会・都邑を用いた例が多 い。(事例は省略)

これに対して，都市をより身近な立場から見る社会思想 家・社会運動家は早くから「都市」を受け入れていたよう で，片山潜の一連の著作（明治 31 (1900) 年以降）や安部 磯雄の著書（明治 35 (1902) 年以降）にはその用例が多く 久られる。(柴田徳衛「現代都市論」には, 都市問題といら 言葉が片山潜の著作に始るとの指摘がある)

このような明治 30 年代の過渡的時期を経て, 遅くとも大 正初期までには, 都市といら言葉はほ济定着をみたようで あり，その背景には都市機能の多様化とそれに伴なら都市 問題への関心の高まりがあったと考党られる。 
都市と犯罪についての一考察

桑 島勝 雄（東北福祉大）

近年, 大都市注ど犯罪の発生率が増加する傾向がみられ るが，犯罪を誘発する都市の環境要素について，仙台を例 として, 次の指標によって 2,3 の考察を試みてみた。
すなわち, 都市に抢ける犯罪の罪種別認知 (発生) 件数 の分布，拈よび犯罪率分布を指標として，犯罪の発生場所 そ, その環境要素の一つである都市の地域構造との関係を

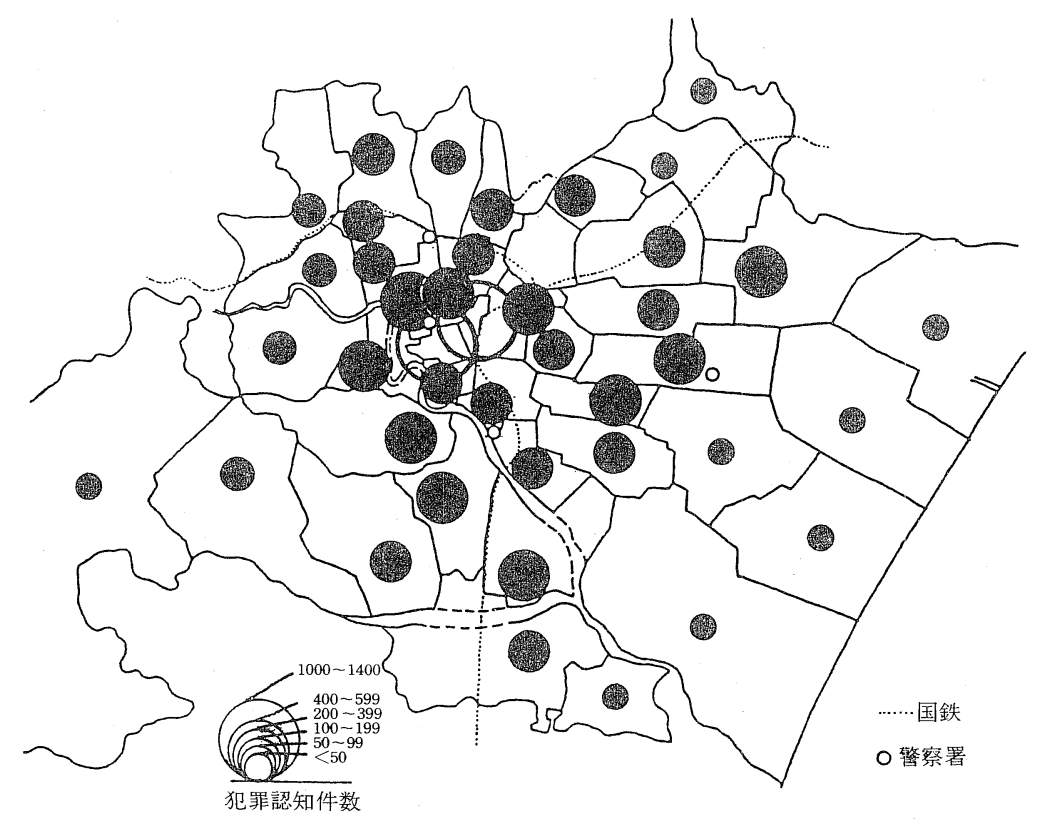

第 1 図 全刑法犯の派出所別認知件数

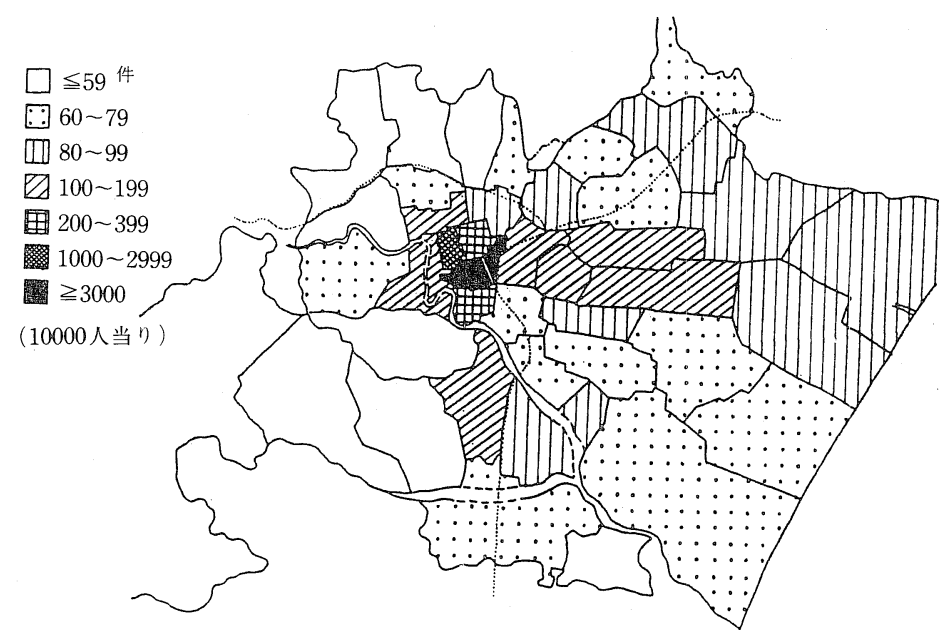

第 2 図全刑法犯の派出所別犯罪率 
検討した。

その結果を要約すると次の諸点が指摘された。

1 仙台市に扔いても，一般的に指摘されているように， 全刑法犯の犯罪率は, 都心部に打いて最高率を示し，そこ を遠ざかるにつれて率は低下し，郊外で最低率を示してい る(第 2 図)。

2 しかし, 罪種別にみると種々の変化がみられ, 特に万 引き。空巣ねらい。事務所荒しなどの窃盗犯は, その犯罪 の発生場所と, 都市機能の分化地域 (ショッピングセン ター。住宅地域・ビジネス街）との間に，密接な関係のあ
ることが認められた。

3 また, 1 で指摘した犯罪率の高率地带は, アメリカの スラム地区にみられるようなその地区の居住者による犯行 地域ではなく， ほとんどが外来者によって犯罪が発生して いる地域である。

4 戦後 10 年間の都市社会生活の混乱期に，一時的に仙 台に形成された都心部周辺の非行地域は，その痕跡をとど めているにすぎないが，そこは現在の犯罪率の最高率地帯 とほぼ一致している。

\title{
研究の体系と研究所の配置
}

\author{
宮川 泰 夫（愛知教育大）
}

1980 年に, 通商産業省は, 1980 年代の通商政策ビジョン に和いて技術立国政策を提言し，それによって，わが国の 技術研究開発能力を高め, 研究所の配置に対しても新たな 政策を樹立しょうとしている。

こうした技術導入, 自主技術育成の政策は, 古くから存 在し，その技術移転の方策と技術育成の機構は，今日，開 発途上国のみならず, 先進国でも大きな関心をよんでいる。 (Miyakawa (1983): Changing industrial structure and transfer of technology in Japan. U.N.C.R.D.)。ここで は，こうした技術開発の中心に位する研究所の配置を，そ の研究体系の進展と関連付けながら体系的に究明してみた いと思う。

今日わが国の研究所の大半は, 首都圈に配置されて和り, 首都東京は，その中枢に位する。この東京から移転した 38 の国立研究機関とその研究交流プラザをもつのが茨城県の 筑波研究学園都市である。この茨城県には, 豊里東部研究 団地だけでなく, 阿見町の三菱油化の中央研究所, 応用研 究所の立地に象徵されるように, 新たな研究所の集積がみ られつつある。しかし, 1982 年現在, 民間の独立研究所 697 所中, 茨城に立地するものは，まだ 17 と少なく, 東京 (134) に次ぐのは神奈川 (128) である。ここは, 横浜市緑区の三 菱化成工業の総合研究所に代表されるように, 先端的な技 術開発を行なら研究所の集積が目立つ。埼玉 (51)・千葉 (31) の両県も, 東海の愛知 (23)・静岡 (17)・三重 (11) 上り も多く, 京阪神の大阪 (100)には及ばないものの, 兵庫 (44), 京都 (24) を上回る。京都に隣接する滋賀は, 東レの開発・ 繊維・エンジニアリング。プラスチックの 4 研究所にみら れるよらに繊維（8）を中心に 14 ケ所が展開するが，この 東レの基礎研究所が鎌倉にあるように，体系的には，下位 に位置する。科学技術庁の調査（1981）によれば，調査対
象の 744 社中 $22.8 \%$ が複数の研究所をもち, そのうち 32 . $6 \%$ が基礎研究となっている。この基礎研究部門は, 三菱電 機中央研究所（尼崎市）や豊田中央研究所（長久手町）の ような少数のものを除いて大半が京浜地区に集中する。三 菱は, この発祥地に応用機器, 生産技術, LSI の三つの研究 所を置くが, 商品開発とデザインセンターは鐮倉に設立し, その機能を使い分けている。これは, トヨタ自動車の場合 も同様であるが, この場合は, 創業以来, 豊田理化学研究 所を東京に置いてきており，これが名古屋に移ったのは, 量 販・量産体制の確立した 1960 年であり，それが名古屋・豊 田の中間の長久手に移転したのは日本の自動車生産が世界 一となり，技術革新のさけばれた 1980 年である。しかし， こうしたトヨタ自動車のような例は例外的であって，日立 のように日立研究所 (1934 年設置)に加光, 1942 年には国 分寺に中央研究所を設け, その後機械(1966), エネルギー （1972）を日立に，生産技術（1971）を横浜，システム開発 （1973）を川崎に配置するような形態が一般的である。これ は, 明治期に設立された 9 研究所中 7 ケ所が京浜に, 2 つが 京阪神に, 大正期の 33 ケ所中 11 ケ所が京浜に, 11 が京阪 神において設立されていることからもわかるよらに，わが 国の工業発展の過程と国公立研究機関の発達過程とが深く かかわっていることは言うまでもない。

これは, 今回行なった 427 社へのアンケート調査によっ ても, 研究所立地の条件として大学, 研究機関への近接性 (68.8\%) を第一にあげていることでもあきらかである。ま た技術者の雇用, 本社への近接性, 先端技術産業の集積, 情 報サービスの集積そいった他の条件も, 首都圏や京阪神地 区は充分充足している。こうした研究所に比べ，応用研究 や高品化研究を主とする開発センターは， $66.8 \%$ の企業が 工場への近接性を第 1 の条件とする。そして, これは一方 
で新製品開発の反応情報の得やすさ $(56.2 \%)$ を求めて，首 都圈を中心とした東海道メガロポリスに展開し, 他方で技 術者や技能者の雇用等の問題と関連して，それ以外の地方 拠点工場の近接地へと立地している。

研究所の立地では，中央官庁への近接性は，それほど重 視されていないが, 1961 年に公布された鉱工業技術研究組 合法に基づく, 民間共同基礎研究機構 72 組合では, 情報・ 交通の便とともに官庁との相互連絡が最も重視されてい る。これは，わが国に打ける伝統的な政治経済的意志決定 機構と深く関連したものである (Miyakawa (1983): Tokyo-metamorphesis of the capital and evolution of urban system in Japan. EKISTICS, 50)。これは，72 組
合中わずか 13 組合が,山ノ手線沿線外に設けられたにすぎ ないことでも明らかである。これは，このらち58 組合の設 立された石油危機以降に限ってみると, 川崎・保谷・大阪 の 3 ケ所にすぎないことでもわかる。こうした基礎研究の 外部化は, 1981 年からの次世代産業基盤技術開発制度でも とられているが，他方，地域フロンティア技術開発や技術 交流プラザの強化テクノポリス等を通して, 名古屋のファ インセラミックセンターに象徵されるよらに地方でも新た な共同研究体系がつくられ, 研究所の配置にも影響を与え はじめている。(宮川（1983）：サイエンスパークとテクノ ポリス. 愛知教育大地理学報告, 57)。

\section{工業に括けるソフトの部分}

板 倉 勝 高（東北大）
現在産業のソフト化といらことが注目されている。これ は元来工業部門に計上されていた開発・研究・企画などの 企業の中枢的部分を別会社として分離させる風潮をいうも のである。このほか不動産管理・輸送・販売なども独立さ せることは以前から行なわれていたし，エンジニアリング 部門とかコンピューターのソフト部門などにもこの例は多 い。

これらの工業から分離した部門は統計上第 3 次産業に計 上されるため, 見かけ上は第 3 次産業の繁栄になり, 第 2 次 産業の相対的哀退となって表現されてくる。脱工業化社会 と呼ばれるゆ劣んである。しかし脱工業化できる部門を持 つ企業は，全企業の中でも大企業でしかなく，この部分は 当然大都市域ことに東京都心部分に集積するであろう。そ してこの他に脱工業化しないまでも，工的作業の現場つま り工業のハード部門と分離した管理・企画・開発・購買・ 販買などの分野が相当量存在している。普通工業の中枢管 理部門と呼ばれる部門だが，中枢でも管理でもない分野も 含まれるので, これを工業のソフト部分として, 現場と対 比して考えたい。

この工業のソフト部門が大都市人口集中要因になってい ることは疑いないが，従来この分野についての研究は多く はなかった。演者は国勢調査に打ける製造業の従業者は, そ の場所で工的作業を怙こなっていない本社, 研究所なども 計上され, 一方工業統計表に掠いてはこれらの事業所は除 外されていることに着目し, この両者の差と, その変動を 工業のソフト部門とその変動とみなし，その動向を明らか にしようと考えた。

ただこの差の内容には工業統計が補促できなかった零細
工業の從業者数が相当程度ふくまれているため, 差自体の 量を直ちにソフト部門とすることはできない。しかし，近 時に和ける工業従業者の減少は大・中小企業で大きく, 零 細階層では汪とんど変動がないことを考慮すれば「差の変 動」をもって工業ソフト部門の変動とみなすことは大過な いものと考えられよう。

調查対象期間は 1960 年から 1980 年までの 20 年間で 1970 年までを前期とし, 1980 年までを後期とする。6 0 年の 差は全国で 138 万人あったが, 1970 年には 200 万人, 1980 年には 231 万人となった。前期に 62 万, 後期に 31 万の増 加であるが，不思議なことに後期の増加量は前期の半数に とどまっている。これは産業のソフト化を示していると考 えてよい。前期に抢いては国勢調査も工業統計表もほぽ同 率の増加をしているが, 後期になると工業統計表では -6.4 \%なのに国勢調査ではー $3.2 \%$ にとどまっている。

ところがこれを各都道府県毎にみると, 工業統計表の方 が国勢調查よりも多いとか, 逆に前期の鹿児島県や愛媛県 のように国勢調査との差の増加分が 2.5 万人とか 4.6 万人 とかに達する県があって，各県毎の検討をすることはかな り困難である。結局大都市域と地方地域とか, 国土外周地 域と大都市縁辺地域 (北関東・北陸・東山・山陽) 位の対 比しかでかないであろら。

李ず 1960 年についてみると東京・大阪をらくむ南関東, 近畿の両地域で差が 934 万人あるが，これは全国の差の $67.5 \%$ に達する。東海は 14.3 万人で約 $10 \%$ あるが,これは 人口や工業の分布に比べてそれ程突出したものではない。 その中で愛知県は 1960 年に $44 \%, 1980$ 年に $46 \%$ をしめ る。 
一方，差の増減をみると東京は前期にすでに -2.2 万人 と絶対減を示して扣り，逆に埼玉・千葉・神奈川 3 県で 25 万人を増している。周辺 3 県の増加量は工業統計表の増加 も77 万人を算しているが国勢調査はそれを上回っている。 この分は東京都心部分のソフト部門に通勤する製造業従業 者で，元来は中枢管理部門と呼ばれていた部門である。と ころがこれが後期になると周辺 3 県では 14 万人の増が あったが，前期の 22 万人よりは減少し，しかも東京が 5.7 万人も減少しているので, 結局南関東では前期 22.8 万人の 増があったのに, 後期では 8.4 万人と前期の $36 \%$ にしか達 しなかった。近畿の場合はもっとはげしく, 後期には約 4.5
万人の絶対減を示した。愛知も 5.9 万人から 1.4 万人と増 加量を減じている。

これに対して地方地域では前期の 13.1 万人から 25.5 万 人とほぼ倍増し, しかも 1 万人以上の増加量を持つ道県は 3 大広域中心都市を持つ所と, 縁辺地域 7 とそれに福島を 数えている。この事実は工業ソフト部分の地方拡散が明瞭 に進行しはじめたことを示すものであると考劣られる。従 来, 筆者は工業配置研究の立場から, 工場が拡散しても中 央のソフト部分は増加するであろらと予測していたが, 後 期の差の増加はそれとは末ったく相反する数字を示した。 この矛盾を合理的に説明するために御教示を得たい。

\title{
技術改良と和紙産地の盛衰
}

\author{
会田隆明 (盈進高)
}

明治末期から昭和 10 年代にかけて,多くの和紙産地では 「技術改良」の名による製紙方式上の変貌が見られた。もち ろん一方では，そらした影響を全く受けず，旧来の製造形 態を貫く紙産地も存在した。いわゆる「技術改良」の概要 を東日本について示すと，別表のごとくである。

これらの改良は, 台頭しつつあった洋紙に対抗する意図 で漸進し，目標とするところは，(1) 安価, (2) 量産, (3) 均 質であった。しかし，この方向に対しては，昭和初期の「民 芸運動」の立場から，洋紙に追随するのは和紙を隇亡させ る以外の何物でもないと, 厳しい批判が興った。

昭和 12１5（1937～40）年に，有栖川宮学術奨励金を受 けて全国各地の和紙産地を調査報告した寿岳文章は, その 克明な実地記録「紙漉村旅日記」の中で，逐一，民芸主義 の観点から批評を加えているが，その中から東日本に関す るものを幾つか抜粋すると次のごとくである。

$\lceil\cdots \cdots . .$. 帳簿用の『飛駒八寸』と称せられる紙, 旧式のは 1 尺 2 寸に 9 寸 5 分の小判ながら，凡そ昔のままの堅実な手 法なので，手に取るからに頼もしいが，その6枚分の大き さの新式のは, パルプの混入るあり，不思議と紙に力がな い。大きく漉くのがいけないのではなく能率万能に凡てを 帰着させようとする近代精神がいけないのである。」(飛駒： 図中A)

$\lceil …$. 信用組合が結成されて工場組織となってからは, で きる紙が不思議にも甚だ味気ないよらだ。 $\mathrm{K}$ 校の S 教授や 県のN技師がビーターを据えつけ製紙の改良をやったと言 らのはこの工場である。従業中の男女が各種の抄紙工程を 交替で行い, 板乾しを廃し, 全部鉄板乾燥をやっている。漉 工も幼時から漉き熟れたのはなく，伝習を受けて従事して いる。漉かれた紙を手に取って見るに，粘りも艶も暖かさ
もない。ともあれいわゆる『改良』が実際は『悪化』であ ることの歴々たる実例は, ここでも見られた。」（秋畑：図 中B）「何の風情もない殺風景なバラックだての中では, 外 は上々の天気なのに，例のパルプ入りの紙を，鉄板に貼り つけて蒸気乾燥をしている。これを改良と思い込ませられ る田舎人は禍なる哉。この共同作業場で漉いている改良障

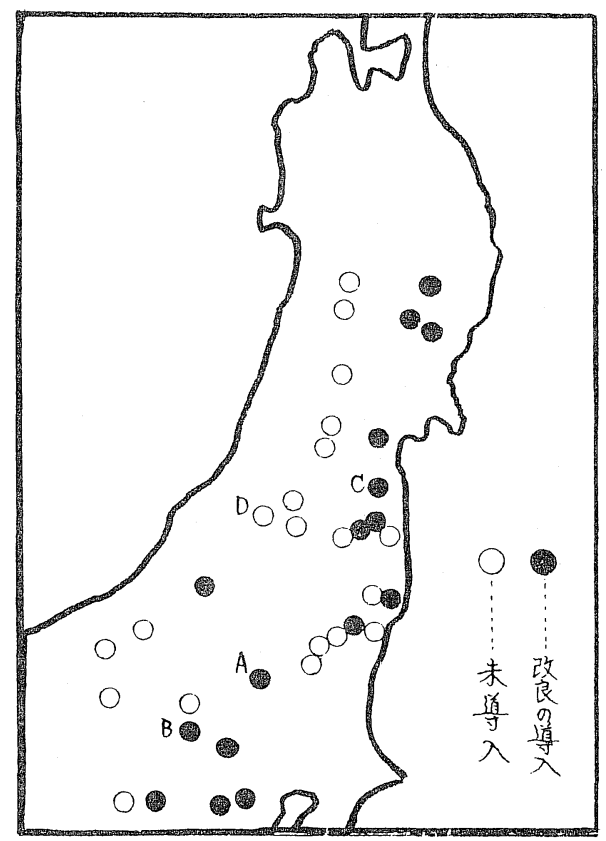

昭和初期の技術改良進行

一一東日本紙産地の場合— 
関東・東北両地方の技術改良の概要

\begin{tabular}{|c|c|c|c|c|}
\hline & & 改良前 & 改 良 後 & 備 \\
\hline 1 & 紙 大 & 「小判」（半紙大程度） & $\begin{array}{l}\text { いわゆる } \\
\text { 「三三判」(2 尺× } 3 \text { 尺 })\end{array}$ & $\begin{array}{l}\text { これが，さらに「倍版」・「八 } \\
\text { 枚版」などに拡大され，渡舟 } \\
\text { や箕桁の大型化への資本投下 } \\
\text { を必要とした。 }\end{array}$ \\
\hline 2 & 原 料 & 楮 100\%（純楮紙） & $\begin{array}{l}\text { パルプ・わら・故紙の混入 } \\
\quad(20 \sim 80 \%)\end{array}$ & \\
\hline 3 & 吒 解 & $\begin{array}{l}\text { 手 打 ら } \\
\text { (カズタタキ台・カズウチ棒) }\end{array}$ & ビーター（電力または石油） & $\begin{array}{l}\text { 組合による協同作業場にも設 } \\
\text { 置された。 }\end{array}$ \\
\hline 4 & 脱 水 & 重し石をのせるかテコ方式 & $\begin{array}{l}\text { ジャッキによる大量・迅速な } \\
\text { 脱水 }\end{array}$ & \\
\hline 5 & 乾 燥 & $\begin{array}{l}\text { 天日乾燥 } \\
\text { (松・杉等の干板使用) }\end{array}$ & $\begin{array}{l}\text { 鉄板乾燥機 } \\
\quad \text { (薪・石油等を燃料) }\end{array}$ & $\begin{array}{l}\text { これによって板目の雅味が失 } \\
\text { われた。 }\end{array}$ \\
\hline 6 & 断 裁 & 定規と包丁による手切り & 断 裁 機 & $\begin{array}{l}\text { 大版紙の大量断裁之規格の統 } \\
\text { 一が可能。協同断裁場の設け } \\
\text { られた紙産地もある。 }\end{array}$ \\
\hline 7 & 者 熟 & 灰水を混入する & カセイソーダを混入する & \\
\hline 8 & 漂 白 & $\begin{array}{l}\text { 清水サラシ } \\
\text { （地方により雪サラシ） }\end{array}$ & サラシ粉を使用 & $\begin{array}{l}\text { 都会向けと称して純白の障子 } \\
\text { 紙がでさるよらになったが, } \\
\text { 楮独特の黄色味の良さが失わ } \\
\text { れだ。 }\end{array}$ \\
\hline 9 & 糊 料 & トロロアオイの腐敗を妨げず & $\begin{array}{l}\text { フォルマリン漬けによりトロ } \\
\text { ロアオイ防腐 }\end{array}$ & \\
\hline 10 & 漉 手 & 女子の座漉きも見られた & $\begin{array}{l}\text { 特大紙は男子でなければでき } \\
\text { ず，また，座漉きは不可能に } \\
\text { なった。 }\end{array}$ & \\
\hline
\end{tabular}

子紙など，值段が安い点を除いて，何が改良なのだろうか。 しかしこの值段とて，もちのいい罒いを考慮に入れれば決 して安くはないのである。」(丸森：図中C)「雪が深く，一 丈以上にも及ぶので，雪の上へ皮を並べて晒す。水でアク 気を抜き, 石のカミソタタキに載せ, 長さ 1 尺ばかりの, 八 ナノキの棒で，坐って打ちこなす。つなぎには草ニレを入 れ，それが足ら煌合は木ニレを使う。筫は岩代でできる 萱筫の，極めて目の細かな，1尺 1 寸 5 分のを用いる。枠は コテと言い，杉の柾で作る。寒の水で男が漉いた紙が最も いいとされる。漉かれて水切りされた組は, カミワケ棒と ミゴ刷毛とで松の干し板に貼り付けられ, 1 尺 1 寸に 9 寸 5 分の出ケ原小判となる。純粋な材料で, 逞しい男手が心を 籠めて毞き上げるのだから，この村の紙が世にも立派なこ とは言うまでもない。最も美しい紙の一つであるとい点 る。」(新渡：図中D)

以上, 民芸的立場からすれば，前表の内容は「改良」か
らぬ「改悪」だったのであり，事実，こらした流れに巻込 まれて和紙の本質を見失い，戦後に復活をせ好まま消隇し てしまった産地が, それらの半数はあったと考えられる(明 治最盛期に約 8 万戸あった漉家が, 終戦直後には約 8 千戸 になっていた)。

和紙の没個性化傾向を，さらに，余儀なくしたのが，昭 和 15 （1940）年以降の戦時体制であり，そこでは原料の楮 までが統制物資に指定されて配給制となり，多くの紙産地 は国策に応じて統一された紙を漉くことが要求された。特 に代表的なのは，米大陸空襲用の風船爆弾の原料となった 「気球紙」の生産であろら。これは楮 $80 \%$ という当時とし ては高級な和紙で，東日本でも福島県の上川崎や埼玉県の 小川などに生産割当がなされた。福島県の場合, 昭和 16 (1941) 年の割当は「三三版」で 50 万枚であった。

戦後, 物資不足の一時期, 「漉けば売れる」として低級紙 が濫造されたが，それらは伝統的和紙の復活に向うもので 
はなく, 経済の安定と共に和紙産地は昭和 30 年代を迎え

て，さらに大規模な淘汰を受ける。

その後現在京で生産を維持している紙産地を大別する と，(1) 機械漉を導入した量産により安定した市場があり
地場産業地域を形成しているもの（市川大門・上川崎・小 川等), (2) 大判手漉に研究と販路拡大を心がけ，書画用紙 等に専門化したもの, (3) 文化財指定を受けた旧来の小判 に回帰し，民芸的特注に応ずるもの，に要約される。

\title{
ナイジェリアの総選挙にみる地域主義
}

\author{
島田周平（東北大）
}

ナイジェリアは, 北部, 東部, 西部の 3 州から成る体制 で 1960 年に独立を迎えた。この 3 州制は, 北部のハウサ/ フラニ, 西部のヨルバ, 東部のイボといった大部族の住み 分けに合致し，また各州が経済的自立性や政治的自治を一 定程度容認されていたために，新生独立国に地方分権化の 基礎を提供するものとなった。これが 3 地域体制と呼ばれ るゆえんである。

この 3 地域を軸とする地方分権化, 経済的自立化指向の 動きが頂点を迎えたのが, 1967 年に勃発したビアフラ戦争 である。この戦争は, 3 地域の一角東部ナイジェリアがビア フラ国として分離独立を宣言することで始まった。この戦 争は 1970 年にビアフラ側の敗戦で終わり, これを境に 3 地 域体制は崩壊への道をたどった。3 地域体制にかわって登 場したのが, 1967 年に新設された 12 州の各州を単位とす る地域主義的傾向，すなわち statismである。これは，特 定部族による州政治の専横的支配を意味する。1967 年に新 設された 12 州は,かつての 3 州が享受していた政治的自由 は与えられていなかった。しかし州政府は連邦政府の裁可 を必要としない州政府歳入をすち, 州行政全般にわたり強 い影響力をもっていた。ここに州内最大部族による州政治 支配問題が起きる政治的経済的理由があった。

このような, 州を単位とする地域主義の解消と, かつて の 3 大部族を軸とする 3 地域体制の根絶を福らって，1966 年から1979年まで続いた軍政は, 次のような政策を実施し た。すなわち (1) 伝統的支配者層の保護育成（州政府の力 を相対化させる), (2) 全国レベルの政党の育成（一地方政 党の追放), (3) 新州創設 (自らの州を持ちたいとする中小 部族の要求充足) 等である。

このような地域主義解消策が実施され, 再びビアフラ戦
争のよらな内戦が起こり得ないことを見極めたらえで, 軍 事政府は 1979 年に総選挙を実施し, その結果に従い民政に 政権を移譲した。

今回とりあげられる 1983 年の総選挙は, 1979 年の総選 挙から 4 年目に実施されたものである。本報告の目的は 1983 年総選挙の結果から，3地域体制から Statism 八の移 行にみられる地域主義の質的変化の方向性を見極めること にある。

分析の方法としては，まず各選挙区（州選挙区，上院議 員選挙区）に抢ける政党別得票率を調へ，そこから投票行 動にみられる地域的まとまりの範囲を推測する。この範囲 を, ここでは政治行動にみられる地域的単位と考え, これ を政治運動に現われた地域主義の基礎単位と措定し，1980 年代ナイジェリアの地域主義の動向を見る。

そのような分析の結果は以下のと扔りであった。

(1) 1979 年の選挙結果との比較で言えば 1983 年には, 州単位の一党支持が減少した。このことは, 3 地域体制から Statism への進展にみられる地域主義の基礎地域の細分化 がさらに進んでいることを意味していると考えられる。

(2) 上記の基礎地域の細分化が，州によって異なる。そ れらは, i) 東部ナイジェリア, ベヌェ低地, ジョス高原 (Anambra, Imo, Niger, Plateau, Benue 各州) 地域では, 上院議員選挙区（各州を 5 分割）よりも小さい地域が基礎 地域となって括り，ii）Cross River, Bendel, Bornoの 3 州では上院議員選手区が基礎地域となって和り, iii) 北部 の Sokoto, Bauchi の 2 州と西部の Ogun 州のみで州と基 礎地域の一致がみられる，といった具合である。

(3) 基礎地域の細分化にみられる州別差異が過去の政治 的支配形態を反映している。すなわち以下に示すと打りで

\begin{tabular}{l|l|l}
\hline \hline \multicolumn{1}{c|}{ 州 } & \multicolumn{1}{|c|}{ 基礎地域 } & \multicolumn{1}{c}{ 植民地前政治形態 } \\
\hline Sokoto, Ogun, Bauchi & 州 & 中央集権的国家, 大部族地域 \\
Cross River, Bendel, Borno & 上院議員選挙区 & 中小国家地域中部族 \\
Anambra, Imo, Niger, & 小 地 域 & 分節国家地域 \\
Plateau, Benue & \\
\hline
\end{tabular}


ある。

以上， 3 地域体制から statism へと進展してきた基礎地 域の細分化が，一部の地域でより一層進み，そのような基 礎地域の細分化にみられる地域差が，植民地前の政治的支 配形態の地域差を反映し，また 3 地域体制時代の遺跡とも いえる中部族の反大部族主義にも影響されていることが明 らかとなった。
ナイジェリアに拈ける地域主義の新しい潮流である基礎 地域の細分化が少くとも表面的には過去の政治的支配形態 や3 地域体制への回帰の方向に進んでいるようにみえる。 このような表面的な伝統的政治支配形態への回㷌現象が， 真の回帰を意味するのか, あるいはをったく新しい地域主 義への展開を意味するのかどらか, 今後さらに研究してゆ きたい。

\title{
中国西域の地域開発と地域問題
}

\author{
今 野 修 平(福井医大)
}

\section{1 中国西域の地域構造}

ここでいう中国西域とは, 中国西北部陝西省, 甘肃省, 新 橿ウイグル自治区を指す。古来シルクロード沿いの地域と して, 東西交流の表舞台として知られ, 多くの民族が興亡 の歴史を繰り返した地域である。

自然環境としては甘肃・新䡬は完全な乾燥地帯に属し, 年 間降水量 $100 \mathrm{~mm}$ 以下の地域が広く拡がり, ゴビまたは沙 漠が大部分をしめる。緑の被覆率は, 農地も含め前者が約 $10 \%$, 後者が約 $3 \%$ である。陝西省は甘肃省東部と共に黄土 地帯であり, 畑作が盛んで雨量も200 から 1,000 mm とな る。

この地域はいずれも多民族居住地域であり西へ行くほど イスラム文化圏となる。新鿕ウイグル自治区は漢民族が少 数民族となっている地域で, 漢民族が主体をなす陝西・甘 肃両省とは異なる様相を示している。

2 地域開発の基本方向

本地域の地域開発は, 解放後扣和むね三つの基本方向か ら推進されているょらに見受ける。

第一は農牧業開発である。本地域は西蔵青海と異なり, 元 来農業が盛んな地域である。陝西省を除き主体はオアシス 農業であるが, 沙漠化とのきびしい闘いの中で農地拡大が 図られている。水の獲得と防風・防砂林の造成が決め手と なるが条件はきびしい。しかし不断の努力が積み重ねられ ているのは，感動的ですらある。

第二は豊かな鉱物資源の開発が進み, これを基礎に素材 型重化学工業の立地を進めていることである。工業化の進 捗度は中国最高であり, 近代的石油コンビナート, 鉄鋼工 場が建設され, 稼動している。また一部では軍需に支えら れた機械工業も開発されている。

第三は世界に冠たる歷史的文化的観光資源を抱えて, 観 光開発の途があるが，この点では外国人への解放が近年よ らやく始まったこと, 輸送能力の少なさ, 宿泊施設等基盤 の不備でやっと着手段階である。本格化すれば特有の地場
産業 (ジュータン, 宝石加工, 農産加工等) への波及も期 待出来る。

しかしこれらの基本方向を軸に，さらに本格的に開発を 進めるためには，いくつかの克服すべき基本課題を有して いることも事実である。

第一に輸送力の強化である。蘭新鉄道一本に依存してい るのでは限界があるが, 地域は広大, 利用密度は少ないと あっては輸送力強化という基盤整備も容易ではない。航空 の活用と鉄道の強化に取組まねばなるまい。

第二に水資源開発の促進である。地下に消えていってい る水の活用策は宿命でもある。

第三に国土管理の問題がある。砂と風と乾燥との闘いは, 自然条件に恵まれた地域よりはるかに長期的な計画的対応 が必要である。既に緑化，交通路維持に精力的努力がなさ れているが，水管理，崩土防止，涸河を含めた河川管理等 残された課題, 固有の課題も多い。

第四に環境容量との調和の上に立った開発方策を持たね ばならないであろう(水草地等)。

現在蘭州, ウルムチ等, 拠点都市は開発促進による建設 需要と, 軍事的拠点としての軍需に支劣られ, 中国で最も 活況を呈している都市のように見受けられる。所詮点在型 にしか居住し得ない本地域に扔いて, 開発の波及効果をど らいら手段で拡げるか, 戦略が求められよう。

また年々急速な勢いで生活水準が向上しているが，これ を今後共支古る基盤は極めて弱い。基盤となる社会資本整 備と産業開発は不可欠だが，元来自給型経済の成立し得な い本地域にとって, 地域的分業の促進と交流の増大への方 向を歩んでいる中国経済の基本動向は, 本地域の開発に とって基本的には歓迎されると判断出来るのではないかと 思われる。

3 本地域の地域問題

開発が急速に進展し, 高生産性産業が導入されているが, 五千年来変らない生活構造と産業も維持されているだけ 
に, 格差問題が深刻化するのではないかと思料される。都 市対農牧地, 商工業従業者対農牧従業者であるがこれだけ に留らず都市居住者・商工業従業者は漢民族が主体をしめ, 農牧従業者はトルコ系, 蒙古系, 西蔵系民族が多くイスラ ム教徒が多いだけに, 民族問題, 宗教問題と結びつく可能 性すら内在している。
また本地域は, 北京, 上海を軸とする大平原地帯との地 域格差が本来大きい，いわば低水準地域であるといら基本 問題の解決にも長い時間を有すると思われる。

さらに中央アジア共通の民族，宗教の分布と一致しない 国境設定と，これからくる政治的軍事的緊張等も，特有の 地域問題の背景にある複雑な一面も有している。

\section{流送作用からみた鉱毒防止施設の機能}

（西吾妻鉱山の酸性毒水について）

佐 藤 五 郎 (米沢中央高) ・加 藤 武 雄 (山形大)

山形県南部の西吾妻天元台地区には吾妻火山に起因する 硫黄鉱床が存在し, 1961 年まで西吾妻硫黄鉱山として硫化 鉱拉よび硫黄を生産していた。しかし，閉山後は天元台お よび松川源流部の明道沢左岸一帯に約 7 万 $\mathrm{m}^{3}$ の鉱㳯が放 置された。しかも, 1967 年と 1969 年の 2 度にわたる豪雨の ため, それまであった鉱涬かん止堤が崩壊し, 鉱毒水は直 接, 明道沢に流出した。これらの除毒施設が停止状態になっ ている 1970 年 11 月〜 1971 年 10 月に加藤ら (1974)により 松川の流送機構が明らかにされている。その後, 通産省所 管の休廃止鉱山鉱害防止工事が進められ，新たに土留壁や 導水路执よび鉱㳯堆積場の一部表面舗装が設けられた。さ らに，天元台北力の大笠山地区に拀いて，それまでの鉱毒 水浸透池にかわって地下 $100 \mathrm{~m}$ ほどのボーリングを 80 本 行ない, 地下浸透法によって鉱毒水を処理している。そこ で筆者らは，松川の現状を知るとともに，新たな鉱毒防止 施設の機能を探るため 1983 年に再調査を行ない, 1971 年 の結果と比較検討を加えたので報告する。

1 明道沢の上流部左岸には 2 つの坑道が放置され, その 坑口から毎分 $3,000 l$ 汪どの坑内水が流出し, そのま明道 沢に放流されている。この坑内水は $\mathrm{pH} 3.2$ の酸性を示し, その硫酸イオン濃度から, 次のような硫化鉱鉱床の酸化反 応がなされているものとみられる。

$2 \mathrm{FeS}_{2}+2 \mathrm{H}_{2} \mathrm{O}+7 \mathrm{O}_{2} \rightarrow 2 \mathrm{FeSO}_{4}+2 \mathrm{H}_{2} \mathrm{SO}_{4}$

$4 \mathrm{FeSO}_{4}+2 \mathrm{H}_{2} \mathrm{SO}_{4}+\mathrm{O}_{2} \rightarrow 2 \mathrm{Fe}_{2}\left(\mathrm{SO}_{4}\right)_{3}+2 \mathrm{H}_{2} \mathrm{O}$

2 鉱㳯を浸透してきた鉱毒水は $\mathrm{pH} 2.2, \mathrm{SO}_{4}{ }^{2-}$ 含有量 $870 \mathrm{mg} / l$ の強酸性を示す。この鉱毒水を集水して地下浸透
させているが，明らかに，この浸透鉱毒水と思われる湧水 が矢沢流域で 2 ケ所確認された。これらの湧水は $\mathrm{pH} 3.0$ と 3.6 で依然硫酸酸性である。すなわち不完全中和の状態で涌 出していることになる。また, 含有成分に関して浸透水と 比較すると, 涌水の鉄含有量は極端に減り，かわって $\mathrm{Na}^{+}$ や $\mathrm{Ca}^{2+}$ 等のアルカリ金属抢よびアルカリ土類金属の増加 が目立つ。

3 松川に㘧ける水質の年平均値を 1971 年と 1983 年を 比較すると，危険率 5\% で次のような結果になる。

1) 両年の值に差の認められないもの（1971年 年)。 $\mathrm{DO}, \mathrm{t}-\mathrm{Re}, \mathrm{SO}_{4}{ }^{2-}, \mathrm{Na}^{+}, \mathrm{K}^{+}, \mathrm{Ca}^{2+}$

2) 1983 年の值が小さいもの (1971年>1983 年)。 8.4Ax, $\mathrm{Cl}^{-}, \mathrm{Mg}^{2+}, \mathrm{Fe}, \mathrm{COD}$

3） 1983 年の值が大さいもの（1971 年<1983 年)。 $\mathrm{pH}$, $\mathrm{SiO}_{2}$

これらのこと, とくに $8.4 \mathrm{Ax} \cdot \mathrm{pH}$ の変動から, 鉱毒防止 施設の効果がうかがえる。

4 松川に和ける各溶存成分の流送量 $\mathrm{Qd}$ と流量 $\mathrm{Q}$ との 間には $\mathrm{Qd}=\mathrm{aQ}^{\mathrm{n}}$ ( $\mathrm{a}, \mathrm{n}$ は定数) の指数関係が成立する。と くに, 主成分である, $\mathrm{Ca}^{2+}$ と $\mathrm{SO}_{4}{ }^{2-}$ については次のように なる。

Qd $\left(\mathrm{Ca}^{2+}\right)=26.9 \mathrm{Q}^{0.407}, \mathrm{Qd}\left(\mathrm{SO}_{4}{ }^{2-}\right)=138 \mathrm{Q}^{0.411}$

両者とも $\mathrm{n}$ 值は 0.5 以下で近似している。

5 松川の年間の総流送量は約 15,600 トンでそのうち約 $40 \%$ にあたる 6,000 トンが $\mathrm{SO}_{4}{ }^{2-}$ で占める。 


\title{
蔵王山「和釜」の近況
}

\author{
佐 藤 五 郎 (米沢中央高) ・加 藤 武 雄 (山形大)
}

蔵王山の和釜については, これまで度々報告されて和り, 最近では加藤ら（1969）の報文がみられる。しかし，ここ 15 年ほどは，まとまった報告がない。そこで, 筆者らは近 年の抢釜の状況と，これまでの報告で明らかにされていな い点を探るため 1982 1984 年再調查を和こない二・三の知 見を得たので報告する。

11983 年 9 月 19 日にトランシットで計測した結果, 湖 表面積 $8.81 \times 10^{4} \mathrm{~m}^{2}$, 最大深度 $26.8 \mathrm{~m}$, 容積 $1.47 \times 10^{6} \mathrm{~m}^{3}$ を示し, 湖岸線の出入りは極めて少なく肢節量 1.05 のほぼ 円形をなす。

2 これまで報告された扣釜の測定結果を比較すると,五 色岳からの火山灰・火山砂の崩落による東側湖岸の埋没と, 西側湖岸に拈ける五色川の浮流物質の堆積が著しい。しか し，全体としての容積は 1955 年以来約 30 年間ほとんど一
定である。

3 水温垂直分布の年間変動から, 湖水は春々秋の年 2 回 全循環し, 冬は逆列成層, 夏は正列成層をなす。すなわち 通常の温帯湖の形態をなす。

4 表面水の水質は, 年間通して $\mathrm{CaSO}_{4}$ を主成分とし, そ の含有量は春季の融雪期に最低となる。また $\mathrm{pH} 3.0$ 〜 3.3 の酸性湖で, 湖沼型は酸栄養湖に属する。

5 水質の垂直分布は, 解水期と盛夏に打いて, 表水層・ 変水層・深水層の化学成層をなす。なた, 湖底付近では, 硫 化物の酸化による $\mathrm{SO}_{4}{ }^{2-}$ 和よび $\mathrm{Fe}^{2+}$ の溶出がみられる。

6 主成分である $\mathrm{Ca}^{2+}$ と $\mathrm{SO}_{4}{ }^{2-}$ の濃度の垂直分布は, 両 者とも 1955 年以来大きな変化はない。つまり, 先の湖盆形 態扣よび水温垂直分布を考光合わせても，打釜における火 山活動の徴候は認められない。

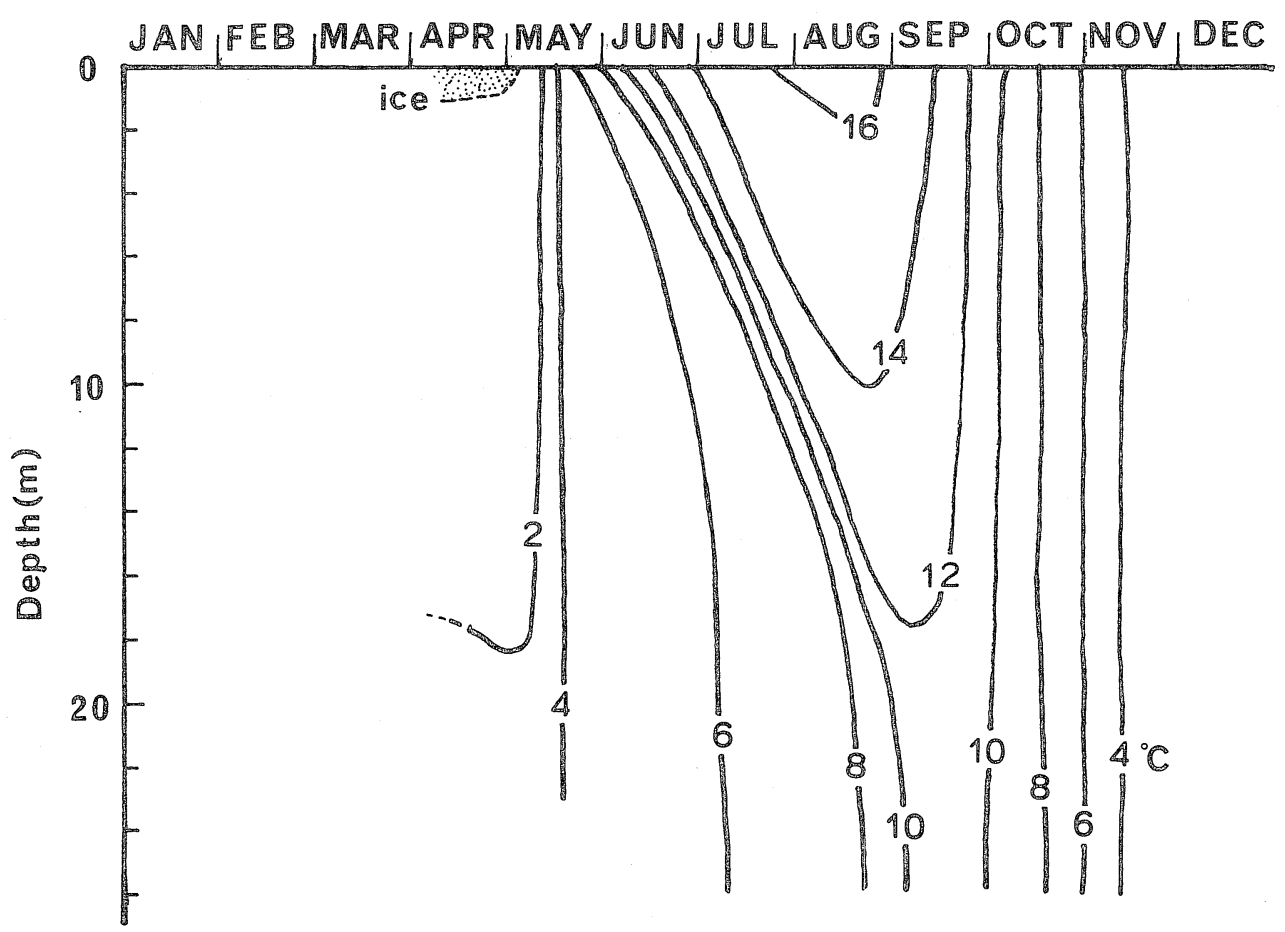

「お釜」に打ける水温分布の年変化 


\title{
豪・米・欧州に和ける ${ }^{14} \mathrm{C}$ 年代測定の現状
}

\author{
小元久仁夫（東北大）
}

地球のごく新しい地質時代を研究対象とする自然科学の 分野において，放射性炭素（14）年代を使用した研究は近 年増加の一途をたどっている。放射性炭素年代は最終水期 以降の地形や気候, 土壤や生物界の環境変遷史を究明する 上で必要な正確な時間尺を研究者に提供している。そもそ もこの年代測定法は1940年代の末にW.F. Libby らに よって天然の ${ }^{14} \mathrm{C}$ の存在が予言され確認されてそれが年代 測定に応用され実用化されたことによる。年代測定の技術 そのものは各国の研究室で改良に改良を加光られて発展し 今日に至っている。そして今日ではコンピュータの導入に よって計測值の信頼性は一段と向上しつつある。

演者は過去 2 年間に豪州, アメリカ合衆国と欧州の幾つ かの年代測定研究所を訪問して年代測定実験室を見学し, 各国の研究者之情報の交換を行った。今回はこの海外視察 の結果について2 3 の研究例と一緒に表題の地域に招け る ${ }^{14} \mathrm{C}$ 年代測定の現状について報告する。

多くの ${ }^{14} \mathrm{C}$ 年代測定研究所に扣いて共通に認められたこ とは，直接計測実験に携っている研究者達は“どれ程古い
年代まで，小さな統計誤差で計測が可能であるがといっ た極限值を求める研究を進めて抏り，なた“どれ位までの 微量試料が得られれば測定が可能がといらこれまた極限 の值を求めての研究が行われていたことである。

一方，放射性炭素年代を使用した研究は多岐にわたる自 然科学の分野に及んで扔り，精度の高い測定值を使用して 細かい議論を展開している論文も見受けられるよらになっ てきた。

このような背景には i) 気体計数法でも特別の地下計測 室を作ったりして計測装置のバックグランドを下げたり, あるいはバックグランドの低い小容積のカウンターを開発 することによって小量 (100 mg 以下) の試料でも年代測定 が可能になったこと。ii）試料が大量に得られれば，液体 シンチレーション法や ${ }^{14} \mathrm{C}$ を濃縮する方法によって 6 万年 以上の年代むでの計測が可能になったこと。iii）長時間を 要する気体計数法や液体シンチレーション計数法に拈いて 実験の制御やデータ処理がコンピュータの導入によって可 能となり信頼性の向上がはかられたこと。iv）加速器を使

放射線計測法（従来の方式）と加速器による直接計測法 （最新の方式）との比較

\begin{tabular}{|c|c|c|c|c|c|c|}
\hline \multicolumn{4}{|c|}{ Radiometric (beta decay counts) on $1 \mathrm{gC}$} & \multicolumn{3}{|c|}{ Direct $\left({ }^{14} \mathrm{C}\right.$ ion counts) } \\
\hline $\begin{array}{c}\text { (1) } \\
\text { Age } \\
\text { years BP. }\end{array}$ & $\begin{aligned} & { }^{(2)} \\
\sim & d p m\end{aligned}$ & $\begin{array}{c}\text { (3) } \\
\text { Time for } \\
\pm 1 \% \text { error } \\
\text { (hours, clays) }\end{array}$ & $\begin{array}{l}\text { Practical } \\
\text { error } \\
T=4 \mathrm{~d}\end{array}$ & $\begin{aligned} &{ }^{(4)} \\
&{ }^{14} \mathrm{C} \\
& \sim \mathrm{cpm}\end{aligned}$ & $\begin{array}{l}\text { Sample } \\
\text { size } \\
\text { mg C }\end{array}$ & $\begin{array}{c}\text { Tine/or } \\
\pm 1 \% \text { error } \\
\text { (min, hours) }\end{array}$ \\
\hline $\begin{array}{l}\text { Modern } \\
11500 \\
230(0) \\
46000 \\
92000\end{array}$ & $\begin{array}{r}14 \\
3.5 \\
0.9 \\
0.055 \\
\text { N.M. }\end{array}$ & $\begin{array}{c}12 \mathrm{~h} \\
2 \mathrm{~d} \\
7 \mathrm{~d} 17 \mathrm{~h} \\
128.6 \mathrm{~d} \\
-\end{array}$ & $\begin{aligned} \pm & 0.35 \% \\
\pm & 0.7 \% \\
\pm & 1.4 \% \\
\pm & 5.6 \% \\
& -\end{aligned}$ & $\begin{array}{r}720 \\
180 \\
45 \\
2.8 \\
0.011\end{array}$ & $\begin{array}{r}10 \\
10 \\
15 \\
70 \\
100 \\
\end{array}$ & $\begin{array}{c}14 \mathrm{~min} \\
60 \mathrm{~min} \\
3 \mathrm{~h} 45 \mathrm{~min} \\
2.5 \mathrm{~d} \\
\text { Measurable } \\
\text { only to } \\
\sim+10 \%\end{array}$ \\
\hline $\begin{array}{c}\text { Background } \\
\text { rates }\end{array}$ & $\geqslant 1.5$ & & & $\begin{array}{c}\text { Few counts } \\
\text { per day }\end{array}$ & & \\
\hline
\end{tabular}

(1) $B P=$ Before P'resent which in radiocarbon dating is before A.D. 1950.

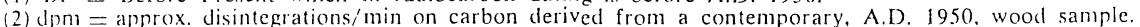

(3) Time (1), required to achieve $a+1 \%$ error of detection is based on the fact that 10000 counts need to be accumblated. $100 \%$ efficiency, which gas proportional counters almost achieve, is used for eviluation of $\mathrm{T}$.

(4) $\mathrm{cpm}=$ observed counts/min of early TIR experiments. Figure of 720 for Modern is minimal; an increase of beam current and detection efficiency in an accelerator dedigated to ${ }^{14} \mathrm{C}$ dating will increase the cpm to $>100()$ for the same sample size. Consumption of sample is estimated to be $<1 \mathrm{mg} \mathrm{h-1}$, and improvements in sample mounting on target will further reduce the datable sample size.

N.M. $=$ Not Measurable.

Error of $0.1 \%$ in the direct counting method is theoretically achievable in a Modern in 1 day and in $11500 y$ old sample in 4 days of counting. 
用した質量分析技術に基づく ${ }^{14} \mathrm{C}$ 年代測定法が行われるよ らになって, 試料の重量が数 $\mathrm{mg}$ 単位で十分になったこと。 等々の技術の改良と発展が行われたことをあげることが出 来る。な敃従来の放射壊変に基づく年代測定法と質量分析 技術により直接 ${ }^{14} \mathrm{C}$ を計測する年代測定法との計測時間和 よび試料重量の比較を表に示した。

各国では放射性炭素年代を使用した最終水期の編年が 着々と明らかにされつつあり, 他の安定同位体の分析結果 をも加味した研究も行われている。日本と豪・米・欧州の 研究レベルを比較すると土壤学, 水文学, 気候学, 水河学 などの分野では数年の遅れがあり,さらに計測技術の開発 についても加速器による年代測定の分野では先進国に比べ
て 5 年以上もの開きが出ている。

科学技術の進歩によってごく近い将来, 南極やグリーン ランドの氷床ュアの年代が明らかにされたり, 各地の泥炭 地や湖沼堆積物それに海洋底堆積物等の年代も決定されて 最終氷期以降の自然環境の変遷とこれにかかわる研究は大 きな進歩をとげることが予測される。遅れまじ日本！

参考文献

Polach, H.A. and Chappell, J.M.A. (1979): Radioisotope dating with accelerators. Its potential for Australian Quaternary and environmental research. Atomic Energy in Australia, 22, 3-12.

\title{
2 ・3 の地すべり地の年代測定結果について
}

\author{
古 谷 尊 彦 (千葉大) ・宮 城 豊 彦 (東北学院大) ・日比野 紘一郎，(宮城農業短大)
}

わが国の地すべり地形は, 北陸地方, 四国地方を中心に 多数見られる。四国地方については, 最近, 寺戸(1981)に よってその位置の分布図が作成され，東北地方については 宮城（1979）や国立防災センターによって精力的にその分 布図が作成されている。また，北陸地方についてはMass -westing（多くは地すべり地に和きかえて考学ることがで きる)といら形で, 磯崎（1977）によってまとめられてい る。

磯崎（1977）の分布図は, かつて Mass-wastig の発生し たことのある, あるいは現に発生している場所の区域が示 されていて,その数は 1,500 個所以上にのぼる。磯崎(1977) はこの Mass-wastingを，i）連続した崩落崖が明瞭に認 められ, 沖積面形成期以降の生成と推定される最も新しい タイプ, ii）頂部崩落崖は開析され, 不明な部分もあるが, 連続的に識別されるもの, iii) 頂部崩落崖はほとんど残さ れていないが，その位置は地形的に読みとれる最も古い夕 イプ, の3つのタイプに区分している。そして, この3つ のタイプのらち, ii) iii) のタイプは下末吉期以降, 沖積面 形成期以前の海面低下期に形成されたものと推定してい る。

磯崎（1977）の資料で，上記の 3 つのタイプの識別がで きるものの総数 1,538 個所を取りあげ，各々について区分 すると，i）は 70 個所, ii）は 630 個所, iii） は 838 個所 となる。これを比率にしてみると，4.6\%, 41\%, 54.5\%とな り, 仮に i) が 1 万年以降, ii)・iii) が 13 万年以降のことと して単純に時間の長さでわりふりしてみると, その割合は $4.6: 7.3$ となり, 1 万年以前の発生数が注ぽ倍になるとい ら結果である。
一方，寺川泳か（1981）はこうした背景をふま方，いく つかの地すべり地で採取した炭化物で ${ }^{14} \mathrm{C}$ 年代測定を行な い, それらの結果から地すべりが多発した時期の存在を推 測している。その時期は，(1) 1,000 yr B.P.前後, (2) 3,000 $\sim 6,000$ yr B.P., (3) 9,000 10,000 yr B.P., (4) 20,000 30, $000 \mathrm{yr}$ B.P. であるといら。しかし, 古谷 (1982) は既存 の ${ }^{14} \mathrm{C}$ 年代測定值をコンパイルしてその結果から厳密な意 味で地すべりの多発期を特定することはまだ早急であると 述べた。

今回はこのようなことをらまえながら，地形的に極めて 明瞭な地すべり地形を示す大規模な鎌池の地すべり地（仮 にこう呼んで和く）と浅草岳の地すべり地で採取した炭化 木の ${ }^{14} \mathrm{C}$ 年代測定の結果执よび地すべり地で採取した資料 による ${ }^{14} \mathrm{C}$ 年代測定結果の扱い方の問題点について述べ る。

寺川ほか (1981) の報告では 23 個の ${ }^{14} \mathrm{C}$ 年代測定值が示 され, このらち茶臼山地すべり地の資料 3 個, 倉並地すべ り地のもの 3 個が示されている。この 2 つの地すべり地は 弘化 4 年 (1847) の善光寺大地震と関係があり, 倉並地す ベり地は大規模な地すべり性崩壊を和こしたと言われ，茶 臼山地すべりは善光寺地震以後の発生（長野県, 1976 ; 望 月，1977）とされている。ことに茶臼山は川中島の合戦の 際一時武田方の本陣がおかれた安定した山だったといわれ る。 ${ }^{14} \mathrm{C}$ 年代測定値そのものは倉並地すべり地の場合 5 , $260 \pm 150$ yr B.P., 5,810 yr B.P., 6140 yr B.P., 茶臼山地す

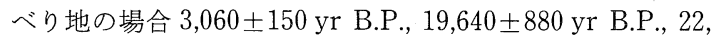
$940 \pm 740$ yr B.P., となっている。このデータは歴史的に考 えられている地すべり滑動の年代と，これとはどのような 
関係になっているのだろらか，といら疑問がある。

今回筆者らが採取した資料の ${ }^{14} \mathrm{C}$ 年代測定值は鎌池地す ベり地の場合, Modern, $370 \pm 90$ yr B.P., $850 \pm{ }_{90}^{100} \mathrm{yr}$ B.P.,

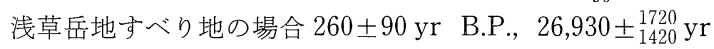
B.P. となっている。同時に採取した腐植物・植物遺体によ る花粉分析の結果では, 前者の地すべり地ではブナ属, コ ナラ属主体, マッ属がそれに続き汪㜔在とかわらない植 生環境となり, 後者の地すべり地ではカバノキ属が極端に 多く，氷期を思わせる環境となっているが，地すべり滑動 によって破壊されたところにカバノキ属が入りこんだこと
を表現した可能性がある。なお浅草岳の ${ }^{14} \mathrm{C}$ 年代測定に供 した資料は, 前者は木の根で, 後者は幹材となっていて, 採 取位置もあまりはなれていず, 両者は一群のものと思われ るものである。

以上のよらに, 常に動く可能性のある土地条件である地 すべり地で採取した資料の ${ }^{14} \mathrm{C}$ 年代測定の結果は，資料の 採取した位置とその地すべり地形発達上の位置との関係が 極めて重要な意味を持ち, 地すべり滑動の年代を論ずるに 当たっては十分慎重に扱う必要がある。

\section{1/50,000 地形図分類図に和ける山地の地形表現について}

阿子島 功 (山形大)。米 地 文 夫（東北大）・赤 桐 毅 一（建設省国土地理院）

1/50,000 地形分類図が，国土調査法にもとついて経済企 画庁 (国直轄) 抢上び都道府県に捈いて事業化され，すで に公刊された図面は500に近づこうとしている。1/50,000 地形分類図はとくに防災図として低地部分に扣いて相当の 成果をあげているが，山地部分に拈いてはその機能は十分 とはいえない。また防災的な面とは別に，地域計画のため の基礎資料としても山地部分についてはその機能をはたし ていないよらに感じられる。

その理由のひとつに, わが国の山地の地形要素の規模を 1/50,000 縮尺によって表現しにくいといらことが考えら れる。しかしながら，作業能率から全国規模の土地分類図 を事業化するためには縮尺 $1 / 50,000$ といら制約ははずす ことはできない。

この限られた条件のなかで, 有意義な山地地形分類の方 法が要求されている。

従来の山地地形分類基準抒よびそれに基づいて,さらに 地域の実情にあわせて工夫された既刊の成果品を調べる と, 次の 3 つの性格が混在していることがわかる。すなわ ち, 概念図的性格・予察図的性格・防災図的性格である。と くに近年, 問題となっているのは, 都道府県 (旧) 方式の 大・中・小起伏山地 (火山地) ・丘陵地といった概念的地形 地域区分の界線を 1/50,000図に表現することである。これ に対する改善案として，傾斜度にもとづく山地斜面分類が 導入されつつあるが (同新方式), 縮尺 $1 / 25,000$ ならとも かく $1 / 50,000$ では予察図（たとえば土壤分類に対する）。 防災図（たと竞ば崩壊予知に対する）として適切な表現は 困難のように感じられる。

すなわち, 経企庁方式の 52 図幅のらち, 傾斜変換線を付
加記号としたものが 5 例あり， らち 3 例は全面にわたって 表記しているが，小起伏面の界線に近い例, 谷型斜面の上 限の界線に近い例，著しく細密である例などあり，一般化 は困難である。また, 崩壞予知に効果ありとされた $1 /$ 25,000 遷急線図を $1 / 50,000$ に縮小してみると図化の困難 性が感じられた。経企庁方式のらちに，急斜面を凸型/等 斉・凹型に細分したものが一例あるが，その界線と崩壊位 置とは一致しない。

地すべり・崩壊付加記号についても, 新鮮な植被を欠く ものは別として,「崩積緩斜面あるいは滑動地塊などをとも なら谷型急斜面あるいはこれに似た形態の谷型斜面」に定 義を抎張して図示すると， ほとんどの斜面がこれになって しまう例 (剣山, 赤湯・上山), あるいは地形単位が細かく て図示できない例（赤湯図幅の一部，花崗岩分布域）など があり，緩斜面のみを図示することにした例（荒砥，印刷 中）もある。上記のように拡張定義された「崩壊・地すべ り性谷型斜面」はある種の傾斜変換線の表現と等価であり (変換線を連続させない表示法), したがって, 防災目的図 として傾斜変換線を図示することは，労多い割には意義の うすい図葉もありえることを意味する。同様の目的で $30^{\circ}$ などをもって急・中傾斜斜面に区分することも，1/50,000 図としては疑問があると発表者の一人阿子島は考学てい る。

付加記号として, 崩積性・地すべり地塊性の緩斜面ある いはその区域を表現することは意義がある。ごく少数の経 験ではあるが，地すべりの活動によって図上に表現された 緩斜面よりは，その下方の急傾斜部に大きな被害が生じた 例があり，区域で図示する範囲についても検討を要する。 
概念図として, 大・中・小起伏山地 (火山地) ・丘陵地・ 山麓地を図示する都道府県旧方式の問題点のひとつは, 1/50,000図上で界線を描くことの他にこれらの定義が明 確でなかったこともある。経企庁方式(緩・急斜面・扣よび 急斜面を水系密度で 2 分すること) 特よび都道府県旧方式 (前述)の意図するところを組又合せると, 起伏量階級扣よ び谷密度階級の組み合せによる地形区設定ができる。しか しこの区分を図上で実形にあわせてくくることは困難であ
る。起伏量扣よび水系密度を図幅を縦横 40 等分する格子に ついて求めて, その組み合せを用いると図上約 $1 \mathrm{~km}^{2}$ のく くりとなり，地形の実形にやや近いパターンが得られる。 な拈,このテーマに関しては多くの問題が残されて抏り, 以上の記述についても必ずしも発表者間の意見が一致して いるわけではない。例えば，山地の表現は，わかりやすく 稜線と谷線とを表現すればよい（米地）といら考方方もあ る。

\section{桜島周辺地域に和ける降下火山灰の堆積分布， 扣よびその上層風との関係}

後 藤稔(ファコム・ハイタック㧣)

過去の噴火に起因する火山灰分布に関する研究例は数多 く見られるが，現実に様々な被害を及ぼしている活動中の 火山から放出される降下火山灰分布については，その資料 に乏しい事も相俟って, 詳しい事は解明されてはいない。そ こで, 唯一集中的な降灰量観測が行われている鹿児島県桜 島火山について，1978 年 6 月から 1982 年 9 月にかけての 県下 58 地点での降灰量㧍よび上層風観測值を用い, 月別の 降灰分布に関する検討を試みた。

季ず，約 5 年の解析期間中，県下に和ける降灰分布の季 節変化に大きな差異はなく, 各年共に大隈半島中央部から 南部地域にかけて広範囲に多量の降灰が認められる。し かし一年を通して月単位で見ると図の様な特徴を示し，季 節により降灰分布域が異なる事が見てとれる。そこで以下 の様な分類を行った。

( I 型) 11 月から 3 月の冬季に打いて, 桜島上層 900 , $850,800 \mathrm{mb}$ では $\mathrm{W} \sim \mathrm{NNW}$ の季節風が卓越し, その結果 火口から南東方向に位置する大隅半島中央～南部地域にか けて集中的な降灰域が形成される。るた，この時期の地上 風風向もほほ同方位を示し地表付近での降灰の分散を抑制 する助けとなっている。

(II 型） 6 8 月に扔いては，上層風は南風の成分を含む 様になり，このため火口の北ないし北西側に位置する薩摩 半島中部から北部の地域に抢いては, 年間を通して最も多 量の降灰が生じる事となる。地上風系もI 型の場合とほぼ 逆になり，この地域へ降灰をもたらす 1 つ要因となって いる。
（III 型）上記 I, II 型の中間期 4，5，9，10 月では，上 層風, 地上風風向共に分散的なため, 対象地域内で均一的 な降下火山灰分布を示す事となる。

また，IＩII 型を通して火山灰分布と最も良く対応する 上層風高度は 850 ないし $800 \mathrm{mb}$ であり, これは桜島の噴 煙到達高度が平均して 1,500 2,000 $\mathrm{m}$ であるためと推測 される。しかし，月によっては上記の平均的などの分布形 にもあてはならないものもあり, これは1ないし数回の噴 火により放出された火山灰が 1 地域に集中して降下したた めと考光られ，分布の季節的特徴をとらえるには，その異 常降灰域を除外して考光る必要がある。

次に上層風風速と火山灰到達距離との関係についてであ るが，火山灰量測定点は火口を中心に半径 $3 \sim 50 \mathrm{~km}$ の範 囲に位置している。そこで火口を原点とする 8 つの扇形の 象限に分村解析を行った。しかし, 個々の噴火毎に火山灰 到達距離と風速との関係を調べるのは資料に制限があり不 可能なため, 火口からの到達距離と降灰量との関係を便宜 的に直線と久なし，その傾きを火山灰到達度の月別指標と して用いた。結果, 直線の傾きと風速は逆相関を示し, 風 速が大であれば火山灰粒子はより遠方に運ばれ，風速が小 であればその逆を示す事が確かめられた。

以上の事柄は, 詳細な資料之解析を行兄ば上層風速之噴 火規模から降灰量を推定し得る可能性を示唆するものと思 われ，本研究がその一助となれば幸いである。しかしその ためには現時点のものよりきめ細かな観測体制が必要であ り，今後の課題と言光る。 


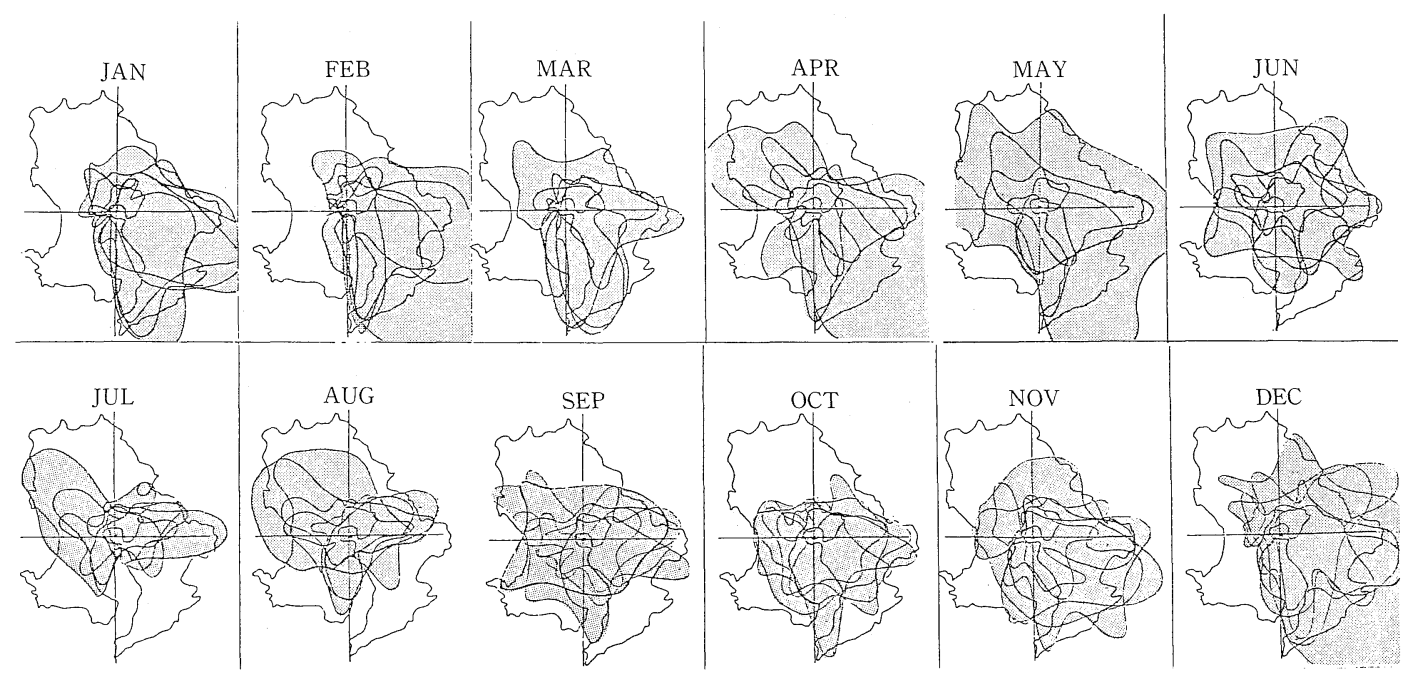

月別に見た降灰域の年変化

(陰影部は月降灰量 $10 \mathrm{~g} / \mathrm{m}^{2}$ 以上の範囲を示す)

盛岡に括ける徳川時代後期の気候

設楽寛（東北大）

本研究は，吉野正敏教授を代表とする総合研究 “世界気 候プログラムに招ける日本の古気候復元計画” の一環をな すものであって，その一つとして盛岡に和ける気候復元を 試みたものである。

盛岡には南部藩家老席日誌が正保元年 (1644) 以降幕末 近くまでほぼ完全に保存されて抒り，その中に天気の記載 が連続的にみられる。東北大学文学部渡辺信夫教授によっ て本日誌がマイクロフィルムに収録されて打り，同教授抒 よび寺田登・渡辺浩一院生の協力によって天気資料を整理 することができた。な扤，太陽暦への換算は内田正男編著 “日本暦日原典”によった。本報告は，1983 年度春季大会に 打ける德川時代中期の気候に続くもので, 1751 年から 1840 年までの 90 年間を対象とし, 主として夏季の季節を扱っ た。

5 月に打ける晴天日数の年々変動は 15 年〜 25 年の振幅 で微変動を繰返しているが, 時代的推移傾向は認められず, 11 年の移動平均によってほとんど平坦化する。

6 月・7 月・8 月と季節が進むにしたがって年々変動が激 しくなり，とくに 1775 年ころから 1790 年ころにいたる安 永・天明・寛政の時代に著しい悪天が頻発している。この 傾向は 7 月下旬から 8 月中旬にいたる 1 か月, 执よび 8 月
に扔いて最も顕著で, 11 年打よび 31 年の移動平均を施す と，1780 年代に晴天日数の著しく深い谷が現われる。それ に対して, 1760 年ころ招よび 1810 年代とに極大が現われ, 対象とする 90 年間に 1 週期半の同期的変化が認められる。

1780 年代に和ける最大の特徵は晴天の最少季が 6 月中 旬拉よび 7 月上旬の 2 つ極小をもつことである。半旬づ つずらせて 10 日単位に晴天率を求め, その経年変動を 31 年移動平均で示すと, 梅雨季に 2 つの晴天最小季が認めら

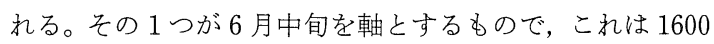
年代の後半に著しく明瞭に現われていたが, その後衰弱し 1780 年代に再び強化され 1780 年代に最盛期をなしてい る。これに対して 7 月上旬の軸は 1770 年代に明瞭な形をと りはじめたもので, 前世紀初頭の 4 半世紀まで顕著な形を 保った。その後晴天日数は増加するが，その季節的時期に ついては現代のそれと一致している。

すなわち, 17 世紀後半に顥著な形をとった 6 月中旬の悪 天季は 18 世紀末にいたって現代の 7 月上旬に乗り移った ことになり，その両季に両またをかけて長期の悪天の季節 を形成したいわば過渡期が天明を中心とする十数年間で, この時代は梅両季に引続く盛夏に掞いて晴天日数の異常な 極小期を形成している。 
以上のことから，天明の異常天候は大気大循環のある種 の転換期にひき起されたものではないかといら暗示を得
る。

\title{
日本海海岸地域に打ける冬季降水の年々変動
}

\author{
境 田 清 隆（東北大）
}

冬季の降水量の年々変動を対象とする場合に打いても, 日本海側と太平洋側との対照は基本的な問題であるが，両 者の負の相関はあまり顕著なものではない。また同じ日本 海側でも北日本は複雑であり, 山陰は他の日本海側地域と は異質の降り方をすることが知られている。今回の報告の 目的は, このように比較的マク口な観点から, 日本海海岸 地域に和ける冬季降水量の年々変動の地域的差異を明らか にすることである。

まず日本全国に対する日本海海岸地域の位置づけを行な 5 目的で, 全国 23 地点の最近 80 年間の冬季 (1 月) 降水量 の主成分分析を行なった。その結果, 第 1 成分は太平洋側 に正, 日本海側に負の分布を示したが，日本海側の変動は， むしろ第 2 成分によって表現され, 太平洋側と日本海側の 変動を単純な負相関として把觉ることの危険性を示してい る。

また北海道から九州に至る日本海海岸近くの 20 地点を 対象に, 地点間の相関係数から年々変動の地域的差異を考 察した。冬季の日本海側の降水量も地域代表性は決して大 きくないが，海岸に近換する地点を選ぶことによって，地 形で複雑化される以前の状態をマクロに把えることができ ると考えた。この結果, 北九州から山陰にかけては北陸地 方と明瞭に負の相関を示し, 東北地方は他の地域と相関が 悪いことがわかった。また 12 月には近隣地点間の相関係数 はかなり高いが，季節が進むにつれて低くなり，より小規 模な擾乱による降水の増加を予想させる。
次にこのよらな地域的差異をひき扣こす循環型について 検討した。イルクーックと根室の気圧差 (季節風指数) は, 北陸地方々正，山陰地方と負の相関となる。仙両地方の $500 \mathrm{mb}$ 面高度の相関場はまつたく逆の分布型を呈し, 山陰 地万はむしろ西日本の暖冬タイプの年に多降水となる。東 北地方の多（少）降水は，北陸地方と同調的であるが，北 陸で多く, 東北で少ない年が相当数存在する。（逆は極端に 少ない。）このような年の $500 \mathrm{mb}$ 高度偏差分布は寒冬タイ プではあるが, 日本の東方海上が著しく負偏差となる東谷 タイプである。

次に地域毎に 1 月の降水量の時系列を平均し, 11 年の移 動平均曲線から長期傾向を検討した。山陰の時系列は, 前 述の第 1 成分の時系列々類似で, 太平洋側地域の変動型々 見なすことができる。これに対し, 北陸・東北・北海道地 域の時系列は第 2 成分と類似で, 約 20 年の周期的変動が認 められる。ただし, 東北では 1940 年前後, 北海道では 1960 年前後のピークが欠落する。

最後に北陸で多降水となった年を選び，東北でも多かっ た年（A）と少なかった年（B）に分け，区内観測所のデー タを使用しやや詳細な分布図を作成した。Aでは，多降水 域は比較的海岸に近接したまま北東に伸びているのに対 し, Bの多降水域は内陸に位置する傾向がある。

今後は，今回明らかになった比較的マクロな循環型の変 動と, 様々なスケールの擾乱との関係を明らかにし, 冬季 降水量の変動モデルを呈示することが求められよう。

\section{冬季の低気圧通過時に和ける中部地方の降水分布の検討}

\author{
田 坂 郁 夫 (奨励研究員)
}

本研究の目的は，冬季の低気圧通過時に打ける特徵的な 降水分布型と，その形成に関わる総観的条件を明らかにす ることである。対象地域は中部地方であるが，今回はこれ に関東地方の 4 都県を加えた。
事例として 1966 年から 75 年の冬 $1 ・ 2 ・ 12$ 月に打いて, 日本付近に南岸低気圧が 1 つだけ存在する日を選択し，そ の日降水量分布図を作成した。例数は 91 例である。 多降水域（各分布図に和ける最多降水量の $1 / 2$ 以上の降 


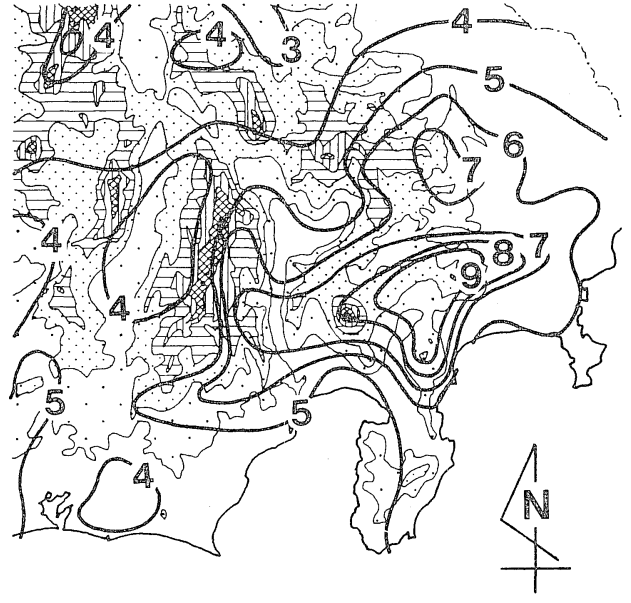

I 型 (左図)・II 型（右図）の平均降水量分布

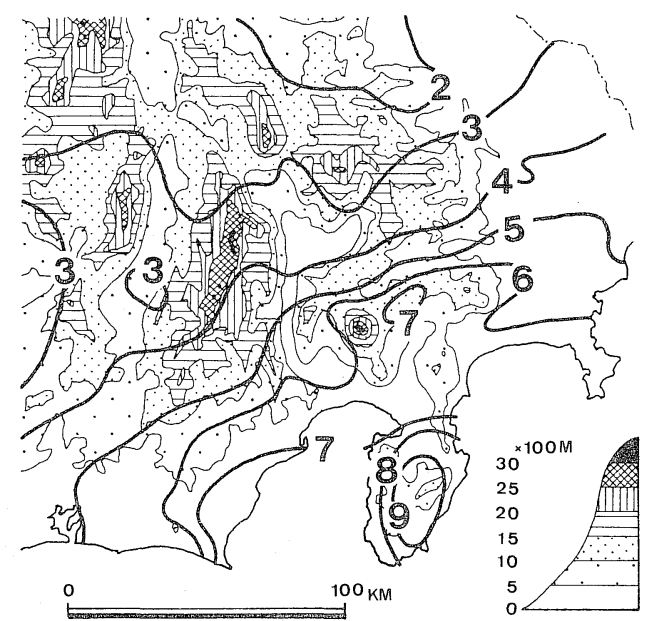

(等値線は各図の最多降水量に対する比率 $(\times 0.1)$ )
水域）の分布をみると，対象地域では能登半島を除く日本 海側之関東南部から静岡県にかけての地域に現われやす い。後者の地域に多降水域が現われた例について，その形 状に注目し降水分布の特徵をみると, 図に示すよらな $2 つ$ の分布型が認められる。1つは, 丹沢山地から赤石山脈の南 扣よび東斜面地域を中心にして山地に多降水域が拡がる分 布型（I 型）であり，他方は，等降水量線がほぼ東西に走 り, 対象地域の南部(沿岸地域)に降水の多い分布型(II 型) である。

降水分布に関わる総観的条件として，はじめに上層の風 向・風速を比較した。用いた資料は浜松の $850 \mathrm{mb}$ 面に沶け る観測值である。ただし, 1 日 3 回の観測値のらち, $850 \mathrm{mb}$ 面で相対湿度 $90 \%$ 以上を観測した時のデータだけを用い, 各分布型発現日の平均風向・風速を求めた。これは次のよ らな考它による。低気圧の移動に伴い風向。風速は著しく 変化するため, 観測值すべてを単純に平均した結果は実態 のない仮想的な風の場を示す恐れがある。また，対象日に 扣いて降水が 1 日中続いていた保証はない。したがって, 降 水分布にも 1 日 3 回の観測値全てが関与することはない。 そこで, 本研究では相対湿度 $90 \%$ 以上の時を降水のあった 時刻とみなし，この時期の条件が降水分布に関与している と考光た。

各分布型の平均風向・風速は I 型 119 度 $(\mathrm{ESE}), 12 \mathrm{~m}, \mathrm{II}$ 型 162 度 (SSE)， $7 \mathrm{~m}$ であり，この風向・風速特に風向の 違いが各分布型を生じさせる要因と考えられる。この考学 が正しいならば,これらの風向が観測された日を選び出し, その平均降水分布図を作成すれば各分布型が明瞭に現われ るであろう。そこで I 型予想日として浜松 $850 \mathrm{mb}$ 面で湿 度 $90 \%$ 以上で $119 \pm 30$ 度の風向が観測された日を, 同じく $162 \pm 30$ 度の風向が観測された日をII 型予想日として, 全 91 例中から選び出し, 平均図を作成した。
その結果，I 型予想日とした日は多降水域が山地を中心 として現われ，この分布型形成に風向が関与していること がわかる。次に風速の条件も加光，I 型予想日を風向 $119 \pm$ 30 度風速 $10 \mathrm{~m}$ 以上, 非 I 型予想日を風向 $119 \pm 30$ 度風速 $10 \mathrm{~m}$ 以下，または風向 $119 \pm 60$ 度以外・風速 $10 \mathrm{~m}$ 以上の 日とし各々の平均図を作成した。その結果, 非 I 型予想日 において山地を中心とする明瞭な多降水域は現われない。 以上のことから，I型分布は風向。風速の両条件が満たさ れた時に生じやすく，その条件からこの多降水域は地形性 降雨により形成されるものと考えられる。

一方，II 型予想日とした日の分布は降水の中心が山地に あり，むしろ I 型に近い特徵をもつ。すなわち，II 型分布 の形成に風向はあまり関与していない。そこで，別な条件 として II 型出現日の低気圧経路を調査したが，I 型日のそ れとの著しい違いは指摘できない。次に，湿度 $90 \%$ 以上を 観測した時の低気圧の位置・温暖前線の位置を両分布型で 比較した。I型に称いて低気圧の位置は冬季の南岸低気圧 の主経路に沿って分布し, 温暖前線の多くは低気圧の中心 から南東に延びる。一方，II 型では低気圧は四国・紀伊沖 に集中して分布し, 前線は中心からほぼ東方に走る。そこ で，II 型予想日の条件を上記のように定め，これに該当す る日を選び出し，その平均降水量分布図を作成すると，そ れは南で多降水，北で少降水の分布を示した。このことは II 型分布にみられる多降水は前線性の降水であり, 低気圧 通過時に扣いて前線が中部地方に接近することにより生じ ることを示している。そして，前線が南東に走りその直接 的影響が現われない時には地形性降雨により山地で多降水 のI 型分布が生じる。

今回の発表では, 冬季の特徴である低気圧通過後の日本 海側の降水分布について検討していないが，これは今後の 課題とする。 


\section{南関東の地上風日変化特性による地域区分}

\section{菊地立（千葉県公害研）}

\section{目的}

地上付近の風は, 海・陸や山地・平地などの熱的な違い の影響により，明瞭な日变化をすることはよく知られてい る。風の日変化は地域によって異なる特徵をるつが, 日変 化を対象としてその地域性について解析した例は少ない。 そこで，南関東地域を例に，地上風の日变化成分のみに注 目し，その特徵の地域的な違いを検討し地域区分を試みた。 4，7，10，1月を各季節の代表として解析したが，ここでは 冬季についてのみ報告する。

\section{方法}

1）資料：関東地方の南半部を対象地域とする。各地方 自治体による大気污染常時監視測定資料から，1978１981 年度の 4 年分について解析した。

2) 対象測定局：対象地域内の測定局は 300 を越光る が，地域により分布の疎密の差が大きく，風の観測条件が 十分でない所も多い。そこで，各地点の月別風配図を作成 して，年により系統的な変化があった地点，隣接地点と大 きな違いを示す地点等を除外した。次に測定網の疎密を平 均化するため, $10 \mathrm{~km} \times 10 \mathrm{~km}$ のメッシュを置さそれぞれ 代表測定局を 1 局ずつ選定した（計 89 局)。

3）地上風日変化成分：各測定局の地上風の $\mathrm{u}$ 成分（東 西), v 成分 (南北) 別にスペクトル解析をすると, 共に 24 時間周期が顕著である。そこで，u， v 成分を 24 時間周期 関数で表わされると仮定し, 最少二乗法により各係数を求 めた。

4）地上風日変化成分のホドグラフ： u, v成分を合成し た風ベクトルの日変化をホドグラフによって示し，ホドグ ラフの各要素（長短軸，位相など）の分布図を作成した。

5）地域区分：ホドグラフの各要素分布を検討し，日変 化の特徵について地域区分した。

結 果

南関東地域を対象に，風の日变化成分の特徴を検討した ところ, 明瞭な地域差が存在することが見出された。1月を 冬季の代表として解析した結果，以下の 6 地域に区分され ることが明らかになった（図）。

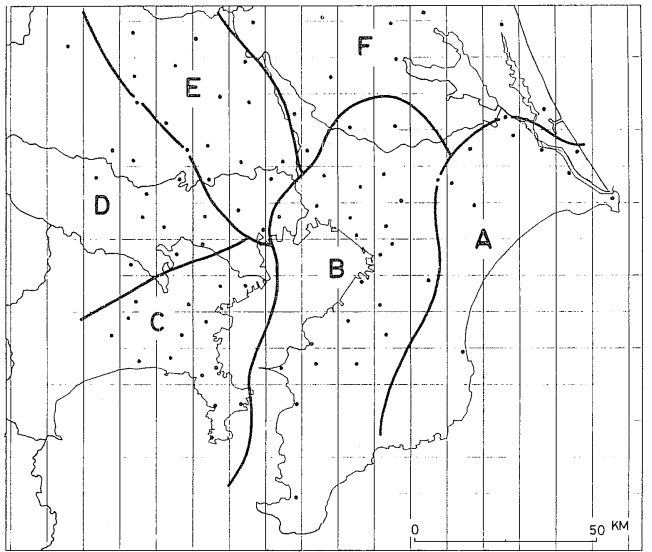

地上風日変化特性による地域区分（1月）

A）房総半島東部地域：日変化成分は夜に南東, 昼に北 西の風向で，反時計回りの風向変化を示す。

B）房総半島西部地域：日変化成分は夜に東, 昼に西上 りの風向で，反時計回りの風向変化を示す。各風向が同程 度の強さで出現し, 特定の風向が卓越する傾向がみられな い。

C) 京浜・相模地域：日変化成分は夜に北，昼に南の風 向で, 時計回りの風向変化を示す。海陸風が他の風向に比 べ卓越する。

D) 関東西部丘陵地域：日变化成分は夜に南西～北西, 昼に北東～南東の風向で，反時計回りの変化を示す。風の 日変化の振幅が大きいが，風向がC地域と対照的である。

E) 関東中央低地地域：日変化成分は夜に南上り, 昼に 北西上りの風向で, 時計回りの变化を示す。しかし, 風の 日変化は小さい。

F) 関東東部地域：日変化成分は夜に東上り, 昼に西上 りの風向で, 時計回りの風向変化を示す。風の日変化の振 幅は中程度であるが，各風向が同程度の強さである。 


\title{
南関東の地上風日変化と大気污染の分布の関係
}

\author{
菊地立 (千葉県公害研)
}

\section{目的}

大気污染物質は風によって運ばれることから，大気污染 の分布は風系の違いに対応して異なるパターンを示すと考 えられる。そこで, 南関東地域を対象に地上風系の日变化 型を設定し，それぞれの型別に污染物質濃度分布を検討し， 風系変化と污染分布の関係を調べた。ここでは, 冬季(1月) の $\mathrm{NO}_{2}$ 濃度についての調査結果を報告する。

方 法

1）資料：南関東地域 89 測点局の $1978 \sim 1981$ 年度の大 気污染常時監視測定資料を用いた。

2）地上風系日変化型：前報に上り，地上風日変化の特 徵に関して対象地域が 6 地域に区分されたので, 各地域か ら 1 測定局を選び，その風がそれぞれの地域の風を代表す るものとした。代表 6 測定局の風の資料を用い，18 時を日 界とし，21，3，9，15 時の 4 時刻の風（ $\mathrm{u}, \mathrm{v}$ 成分）を变数 とし，日付をサンプルとして主成分分析を行った。さらに， サンプルスコアを固有值で重及付けしてクラスター分析を 加光，対象期間のすべての日をグループ化した。その妥当 性を確認するため, 代表 6 測定局の日平均風拉よび気象台 のデータ等を検討し，必要な部分については修正を加党た。

3）污染物質濃度分布：地上風系日変化型別飞, 各測定 局の $\mathrm{NO}_{2}, \mathrm{O}_{\mathrm{x}}$ の時刻別平均濃度, 標準偏差, 高濃度出現確 率を計算した。

結 果

1). 風系日変化: 南関東地域を対象として風系日変化 （18 時日界）を分類した結果， 4 年間の 1 月（計 124 日）が $\mathrm{A} \sim \mathrm{H}$ 型の 8 グループとなった。それぞれの対象日は, $\mathrm{A}$ 型 の 5 例, C型の 22 例を除くと 10 例前後であった。ただし， 代表測定局の日平均風速が $8 \mathrm{~m} / \mathrm{sec}$ 以上の日を強風日之 して除外した (9 例)。各型別に代表測定局の日平均風拉よ び日中の天気 (千葉測候所)を比較すると, 各型の間に異 なった傾向がみられ，また $\mathrm{NO}_{2}$ 高濃度の出現日が特定の日 変化型に集中する傾向が認められた。 $\mathrm{A}$ 型, $\mathrm{B}$ 型は弱風で あるが， $\mathrm{A}$ 型は北西風が卓越して天気が悪く， $\mathrm{B}$ 型は南南 西風が卓越して天気が良い。C $\sim \mathrm{E}$ 型は共に北西風が卓越 するが，C, D, E 型の順に風速が増加し, 晴天の割合が高く なる。 $\mathrm{F}$ 型は北北西風が卓越して天気が良い。 $\mathrm{G}$ 型は北東 風で天気が悪く, $\mathrm{H}$ 型は南西風で天気が良い。 $\mathrm{NO}_{2}$ 高濃度 日はB型とC 型集中する。
各風系日変化型には以下の特徵が認められた。

$\mathrm{A}$ 型：夜から朝にかけ関東平野の北～北西風のほか, 房 総半島から東京湾に向ら南東の陸風が吹く。昼は相模湾か ら南西風が進入し, 北西風との間に収束線を形成する。

$\mathrm{B}$ 型：夜から朝にかけては $\mathrm{A}$ 型と同様であるが，午後は 南西風が南関東全域に卓越する。

$\mathrm{C}$ 型：夜から午前中まで大部分の地城が北西風で, 房総 半島の陸風は明膫でない。午後に $\mathrm{A}$ 型と同様に南よりの風 が進入し，東西方向の収束線が形成される。

$\mathrm{D}$ 型：全体として北～北西の風が卓越するが，房総半島 南部の夕夜から早朝にかけ南上りの風が吹く。午後は風速 が大きくなる。

$\mathrm{E}$ 型: 房総半島の南風がなく, 終日北西の風が全域に卓 越する。風速の地域差が小さい。

$\mathrm{F}$ 型：北西〜北北東の風が全域に吹き, 風向風速子もに 地域差が少ない。他の型と異なり, 午後には風速がやや減 少する。

$\mathrm{G}$ 型：北東の風が終日卓越する。風速が比較的大きく, 風 向・風速の地域差が少ない。

$\mathrm{H}$ 型：全体として西よりの風である。対象地域の南部は 南西風, 北部は北西風のため, 中央に東西方向の収束線が 形成される。夜は風が弱いが，午後は南部地域を中心に風 速が増大する。

2）風系日変化型と $\mathrm{NO}_{2}$ 濃度分布の関係

$\mathrm{A}$ 型の日は東京湾周辺地域で $\mathrm{NO}_{2}$ 濃度が相対的に高く, その中心は東京都心部から横須賀にかけての東京湾西岸部 にある。

B 型の日は, 弱風で東京海に風の收束域が形成される影 響で, 東京湾を囲む地域全体で $\mathrm{NO}_{2}$ 濃度が高くなる。また 高濃度域が広い。

$\mathrm{C}$ 型の日は, 北西風のため高濃度域が $\mathrm{B}$ 型に比べ南に偏 り, 高濃度域が狭くなる。

$\mathrm{D}$ 型の日は, $\mathrm{C}$ 型より北西風の風速が大きくなるので, 全 体に濃度が低くなり, 相対的な高濃度域がさらに南へ偏る。 比較的風の強い $\mathrm{E}, \mathrm{F}, \mathrm{G}$ 型の場合は, $\mathrm{NO}_{2}$ 濃度が低い。 $\mathrm{H}$ 型の日は，西よりの風で夜から午前中まで風速が小さ いので, 風下の荻城県も含めて広範囲で $\mathrm{NO}_{2}$ 濃度が上昇す る。風上側に当る三浦半島や房総半島南部は濃度が低い。 
海南島の植生

$$
\text { 牧田肇（弘前大） }
$$

海南島は北緯 $18^{\circ} 20^{\prime} \sim 20^{\circ} 10^{\prime}$, 東経 $108^{\circ} 37^{\prime} \sim 111^{\circ} 03^{\prime}$ に ある，中国では南海諸島を除いて最南の島である。面積は $33,907.7 \mathrm{~km}^{2}$ で我が国の九州よりやや小さい。中国は現在, 東北部や青海省とならんでこの島の開発に重点を置き，政 策的にはゴムを主とする熱帯工芸作物の生産が推進されて いる。

この島の中央部にはやや南偏して山地があり, その周辺 を丘陵地・台地がとりまいている。沖積低地の発達はよく ない。山地は花崗岩を主体とし, 主峰五指山(海抜 $1,879 \mathrm{~m}$ ) をはじめ, $1,000 \mathrm{~m}$ をこす峰が多数ある。山地をとりまく丘 陵地・台地は海抜 $200 \sim 500 \mathrm{~m}$ の高位丘陵, $50 \sim 200 \mathrm{~m}$ の低 位丘陵, $50 \mathrm{~m}$ 以下の海岸台地の 3 つに区分される。高位の ものは開析が進んでいる。

気候は中国の気候区分では北熱帯ないし熱帯に区分され る。年平均気温は $22.7 \sim 25.2^{\circ} \mathrm{C}$ であるが山地ではより低く なることが予測される。寒期の北東気流による低温のため, 特に北部で熱带作物に被害がでることがある。年降水量は 場所により $800 \sim 900 \mathrm{~mm}$ から 2,800 $\mathrm{mm}$ 之変化が大きい。 降水量の多いのは南東部, 少ないのは西部である。5 10月 が雨季，11〜4月が乾季となる。

フロラの面から見ると中国は大部分が全北植物区系界に 属するが，広西壮族民族自治区の南岸一帯扔よび海南島を はじめとする広東省南岸は旧熱帯に含まれる。海南島につ いて見机ば，種子種物は 180 科 1,000 種あまり，らち $80 \%$ が熱帯系で，40\% が固有種である。ただし，熱帯も北縁な ので, 南アジア熱帯に典型的なフタバガキ科, ニクズク科
などの種は比較的少なく，ことに山地ではブナ科の常緑樹 が多くみられる。

海南島の森林は山地に成立する山頂コヶ低木林, 山地常 緑広葉樹林, 山地雨林, 丘陵地台地汇成立する常緑モンス一 ン林, 雨緑モンスーン林, サバンナ, 海岸に成立するマン グロープに分けられる。このらち面積の大きいのはカキノ キ科, クスノキ科などの常緑樹に一部キワタノキ，モモタ マナ,フゥなどの落葉樹をまじ光た常緑モンスーン林と, チ ガヤ, エノコログサなどイネ科草本にアデク属, キワタノ キ,クヌギなど混じ壳たサバンナである。前者は島の北部。 北東部, 後者は南部・南西部に広くみられるが, 低位置の ことでもあり破壊がいちじるしい。山地林では山地雨林が 広い面積を占める。この森林にはフタバガキ科, イチジク 科, レイシなど熱帯系の種の活かに, アカガシ亜属, クリ ガシ属, マテバシイ属などブナ科の常緑樹が多数含まれる。

マングローブの面積は小さく, 破壊もはげしいが，構成 種は18 種にのぼり熱帯の特徵をよくあらわしている。

海南島は九州とほぼ同面積ながら人口は九州の半分にみ たない。それにもかかわらず，九州が $73 \%$ の森林率をもつ のに対して，同島の森林率は $12 \%$ にすぎない。このよらに 森林が少ない原因は, 建材や薪炭材としての伐採もあるが, 主として少数民族による焼き烟耕作があげられる。焼き畑 は主に海抜 500〜1,000 $\mathrm{m}$ にいたる地域で行なわれ，山地の 森林の破壊は全島におよんでいる。

海南島の開発にあたっては, 森林の回復と土地の効率よ い利用が重要な問題であると考光られる。

\section{4 年度春季学術大会巡検報告}

今年度の巡検は 5 月 21 日に, 「仙台藩奥州街道の集落 一宿駅機能を中心としてー」といらテーマで行われた。コー スは次の通りである。仙台 $\rightarrow$ 岩沼 $\rightarrow$ 梘木 $\rightarrow$ 船迫 $\rightarrow$ 大河原 $\rightarrow$ 金ケ瀬 $\rightarrow$ 宮 $\rightarrow$ 白石 $\rightarrow$ 斎川 $\rightarrow$ 越河 $\rightarrow$ 仙台。このテーマを選ん だ理由は, 近年の増改築により歴史的遺構が少なくなりつ つあること，また，集落を迂回するバイパスが建設された ため, このコースを通ることはあっても旧街道筋をみる機 会が少ないと予想されるためである。

岩沼は城下町・宿場町・竹駒神社門前町であると同時に, 寛文 4 年(1664)に開始された阿武隈川舟運の要所でもあっ た。阿武隈川左岸の玉崎で渡辺家を見学した。艜(ひらた 舟）肝入をつとめた渡辺家は現在でも「問屋」と呼ばれて 扮り, 御城米蔵・御成用屋敷が残存している。实た河岸に
は船付場跡が現存している。

大河原は，宿駅としての機能のほかに，代官所・御仮屋 が置かれ，街道の分岐点として民政の中心地としての機能 ももっていた。江戸期・明治期の商家・民家を見学した。ま た，このコースの宿駅は規模が小さく，旅籠をもつものが 少ないが, 集落の南端に江戸末期に建てられた 2 階建のも のが残存している。

金ヶ瀬は，伊達領と片倉領との境界に位置する。町並み が「くの字」に折机曲がる本町・新町境の地点より東の家 屋はすべて仙台方向(北)を向き, 西の家屋は白石方向(南) を向いている。比較的新しく新・改筑された住宅でも旧来 の伝統を守っているのは驚くべきことで，非常に特異な景 観を示している。 